$9=0$

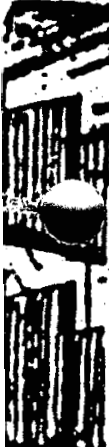

(1)

IIII:

مربم

$E U-78-C-01-6604$

THERMAL GRADIENT UTILIZATION CYCLE (TGUC) FOR POWER GENERATION USING THERMAL VAPOR PUMPING AND HYDRG-PUMPED STORAGE WITH GEOTHERIMAL HEAT, WARM WATER ANDIOR SOLAR ENERGY SOURCES

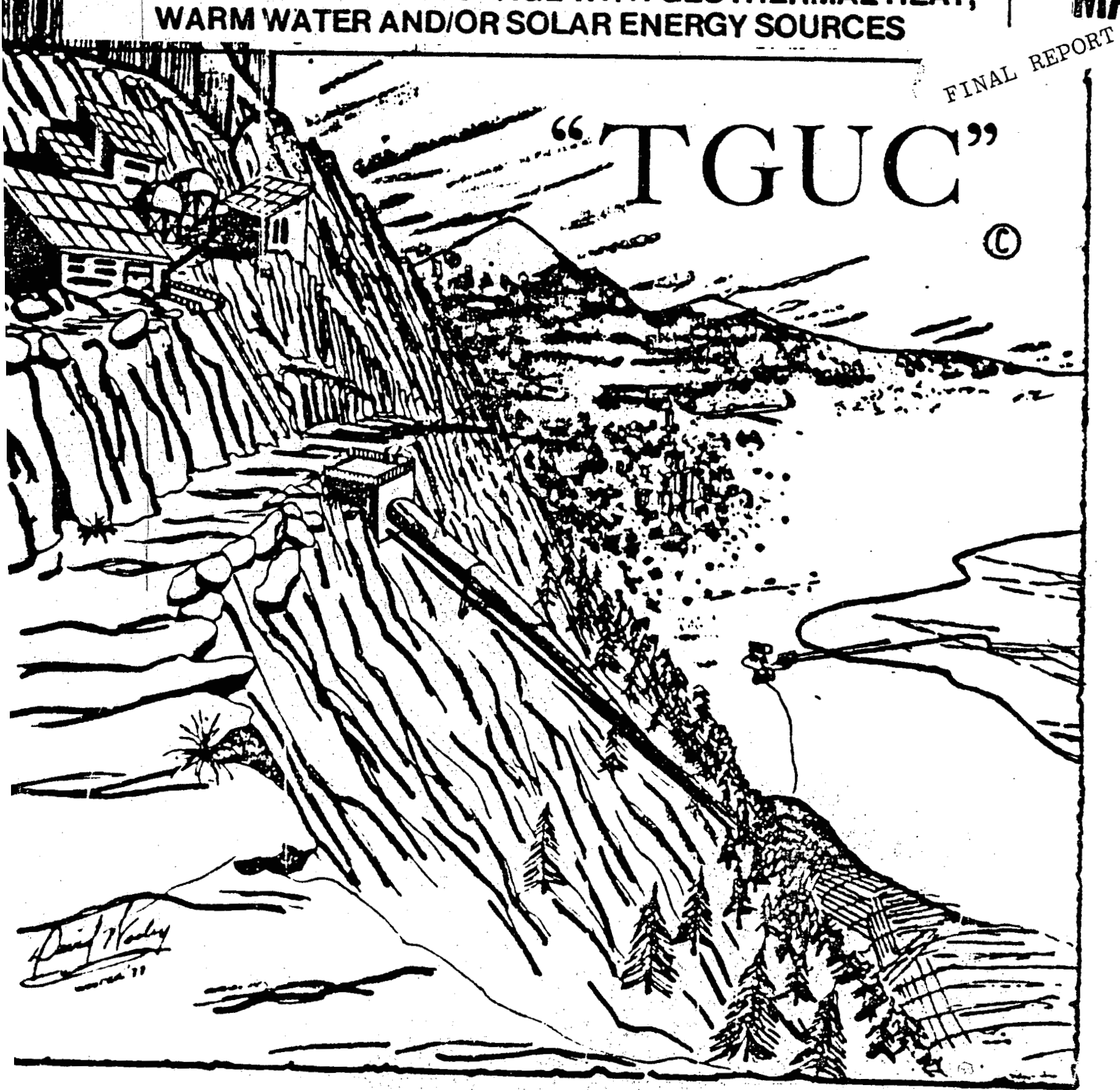

Sidney A. Parker, P.E.

2lst Century Power Generation Co.

P.O. Box: 14606

Fort Worth, Texas 76117

(817) 834-5081 


\section{DISCLAIMER}

This report was prepared as an account of work sponsored by an agency of the United States Government. Neither the United States Government nor any agency Thereof, nor any of their employees, makes any warranty, express or implied, or assumes any legal liability or responsibility for the accuracy, completeness, or usefulness of any information, apparatus, product, or process disclosed, or represents that its use would not infringe privately owned rights. Reference herein to any specific commercial product, process, or service by trade name, trademark, manufacturer, or otherwise does not necessarily constitute or imply its endorsement, recommendation, or favoring by the United States Government or any agency thereof. The views and opinions of authors expressed herein do not necessarily state or reflect those of the United States Government or any agency thereof. 


\section{DISCLAIMER}

Portions of this document may be illegible in electronic image products. Images are produced from the best available original document. 


\title{
TECHNICAL AND ECONOMIC FEASIBILITY OF A THERMAL GRADIENT UTILIZATION CYCLE (TGUC) POWER PLANT
}

\author{
Final Report \\ prepared by \\ Ashok M. Raiji \\ David A. Renfroe \\ Dr. Thomas R. Lalk

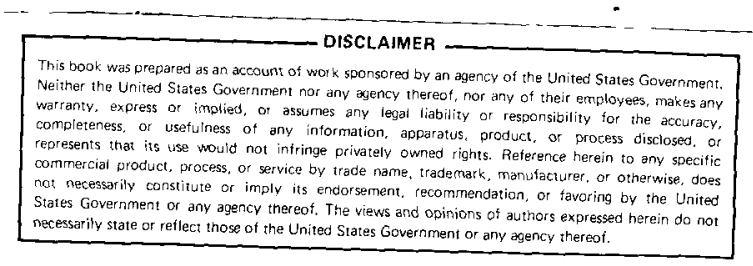 \\ Mechanical Engineering Department \\ Texas A\&M University \\ College Station, Texas 77843
}




\section{ABSTRACT}

The technical and economic feasibility of a Thermal Gradient Utilization Cycle (TGUC), a new concept in power generation, was investigated. Power is generated by exploiting the natural atmospheric temperature gradient. A Low grade energy source is used to vaporize a fluid which rises in a pipe to a higher elevation where it is condensed. The cycle is comp ated by passing the condensed liquid through a turbine as it returns to the lower elevation.

A digital computer model was developed and used to simulate the operation of the cycle and to conduct a parametric study. Life cycle cost analysis and energy analyses were conducted for the specific case of a TGUC using the ambient air at the lower elevation as an energy source.

Although the cycle has a low thermal efficiency and is site specific, it is technicaliy feasible. variations in mass flow rate of the working fluid and elevation were found to affect the cycle power output to a large extent.

The investment cost of a hypothetical 10 megawatt TGUC power plant was determined to be $\$ 3,080$ per kilowatt, with life cycle bubbar costs olelectricity ranging from 47 to 55 Mills per kilowat-hour depending on the method of Einancing.

Results of the energy analyses showed that a TGUC system would have a positive net energy anc a second law 
efficiency of 23 percent for the case of a TGuC system using the atmosphere as an energy source. 
TABLE OF CONTENTS

Page

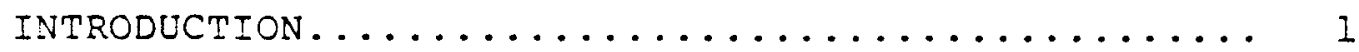

TECHNICAL DESCRIPTION AND ANALYSIS OF THE

THERMAL GRADIENT UTILIZATION CYCLE.............4 4

Operating Principles................ 5

TGUC Computer Model.................. g

Atmospheric Thermal Gradient system........ 14

Parametric study..................... 21

Low Quality Energy Conversion Unit........ 28

ECONOMIC ANALYSIS.................... 30

Cost Inputs......................... 31

Life Cycle Cost Analysis.............. 34

Results.......................... 39

ENERGY ANAIYSES..................... 46

Net Energy Analysis................ 46

Second Law Analysis.................... 59

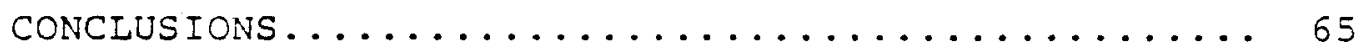

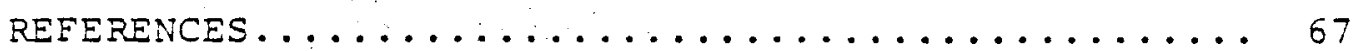

APPENDIX A............................ 70

Momentum Equation. ................. 70

Energy Equation....................... 72

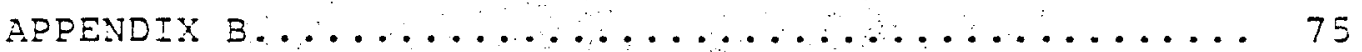

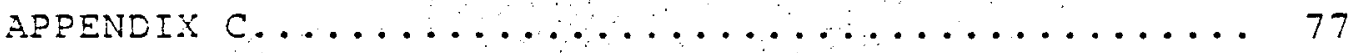

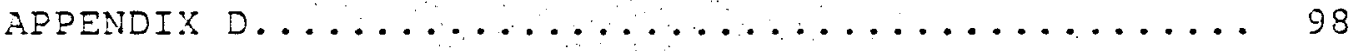

Customary Method.................. 98 
Life Cycle Cost Analysis................. 99

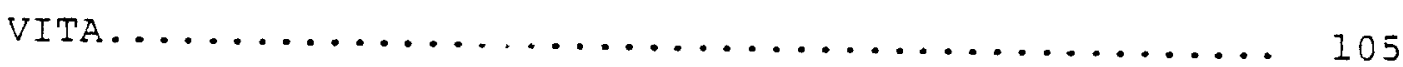


Table 1 Construction costs of a $10 \mathrm{MW}$

baseline TGUC system in constant 1979 dollars..... 32

Table 2 Einancing schemes.............. 33

Table 3 Average annual Eixed charges as a

percentage of total investment for a. TGUC

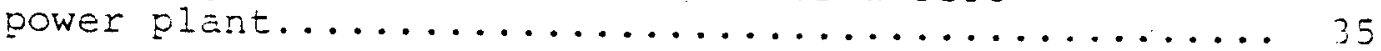

Table 4 . Busbar cost of electricity for a

baseline $20 \mathrm{MN}$ TGUC power plant............... 0

Table 5 cost of power of various power

generation technologies................... 4 I

Table 6 Life cycle busbar costs of electricity

of a baseline $10 \mathrm{MW}$ TGUC power plant............ 45

Table 7 Energy embodied in the average output

of selected incustries.................... 50

Table 8 Nomenclature for energy

inputs ara outputs.................... 53

Table 9 Inaices of system performance......... 55

Table 10 Energy expenditures for

a 10 Mr TGUC power plant................. 57

Table 11 TGUC inputs, outputs and

indices of system performance................60

Table 12 Energy cost of electricity of

various power generation technologies...........6 61

Table 13 second law efficiencies of

single baseload electric power plants.......... 64 
Page

Fig. I Schematic diagram of the Themal

Gradient Utilization CYcle................. 6

Fig. 2 Temperature-entropy diagram of the Thermal

Gradient Utilization Cycle................ 7

Eig. 3 pressure-specific volume diagram of the

Thermal Gradient Utilization Cycle............. 7

Fig. 4 Computational model for flow

in TGUC vapor pipe..................... 1 I

Fig. 5 Configuration of a $10 \mathrm{MN}$ Thermal Gradient

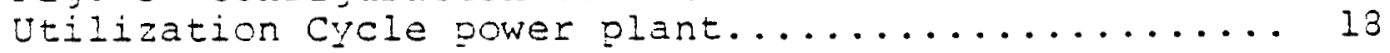

Fig. 6 Effect of televation on saturation

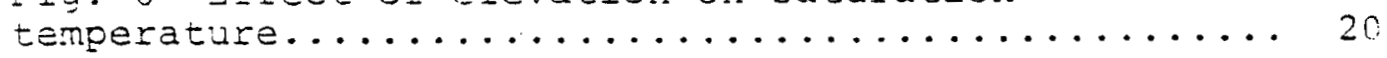

Fig. 7 Effect of pipe size on power output....... 22

Fig. 8 Effect of temperature gradient on

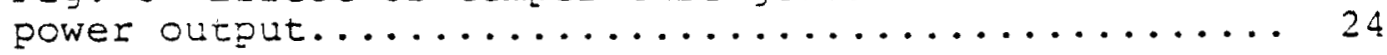

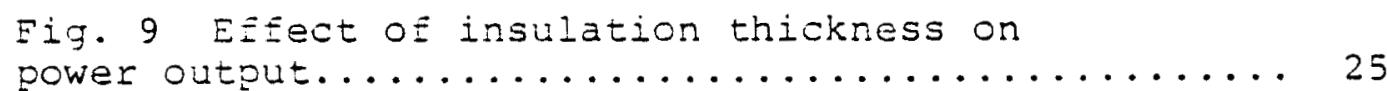

Fig. 10 Effect of elevation on power output...... 26

Fig. 11 Effect of mass flow rate on power output... 27

Fig. 12 Year end interest rates............. 43

Fig. 13 Labor and materials escalation factors.... 44

Fig. 14 Electrical energy system with

$n$ dizEerent energy forms.................. 52 


\section{NOMENCLATURE}

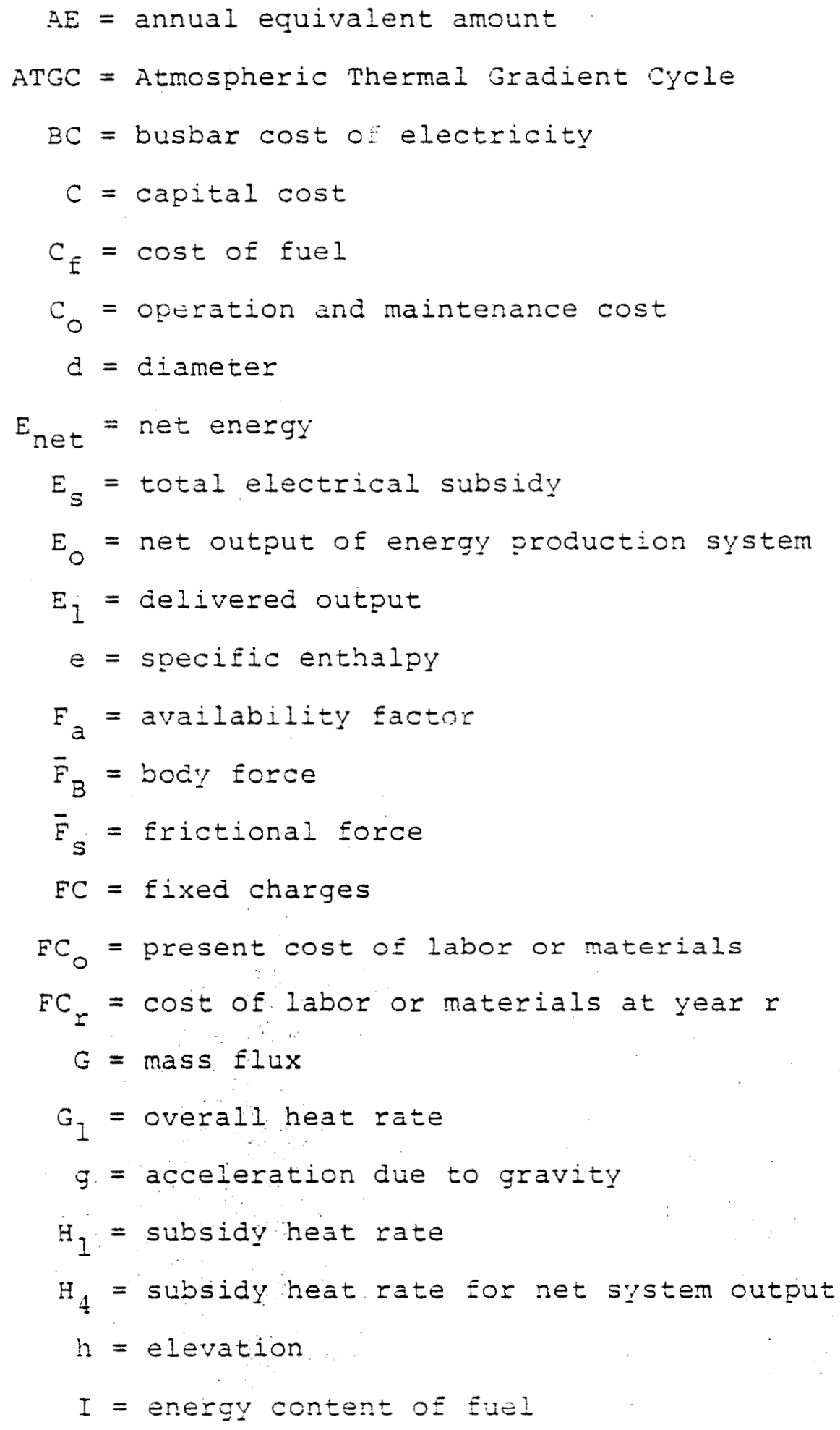




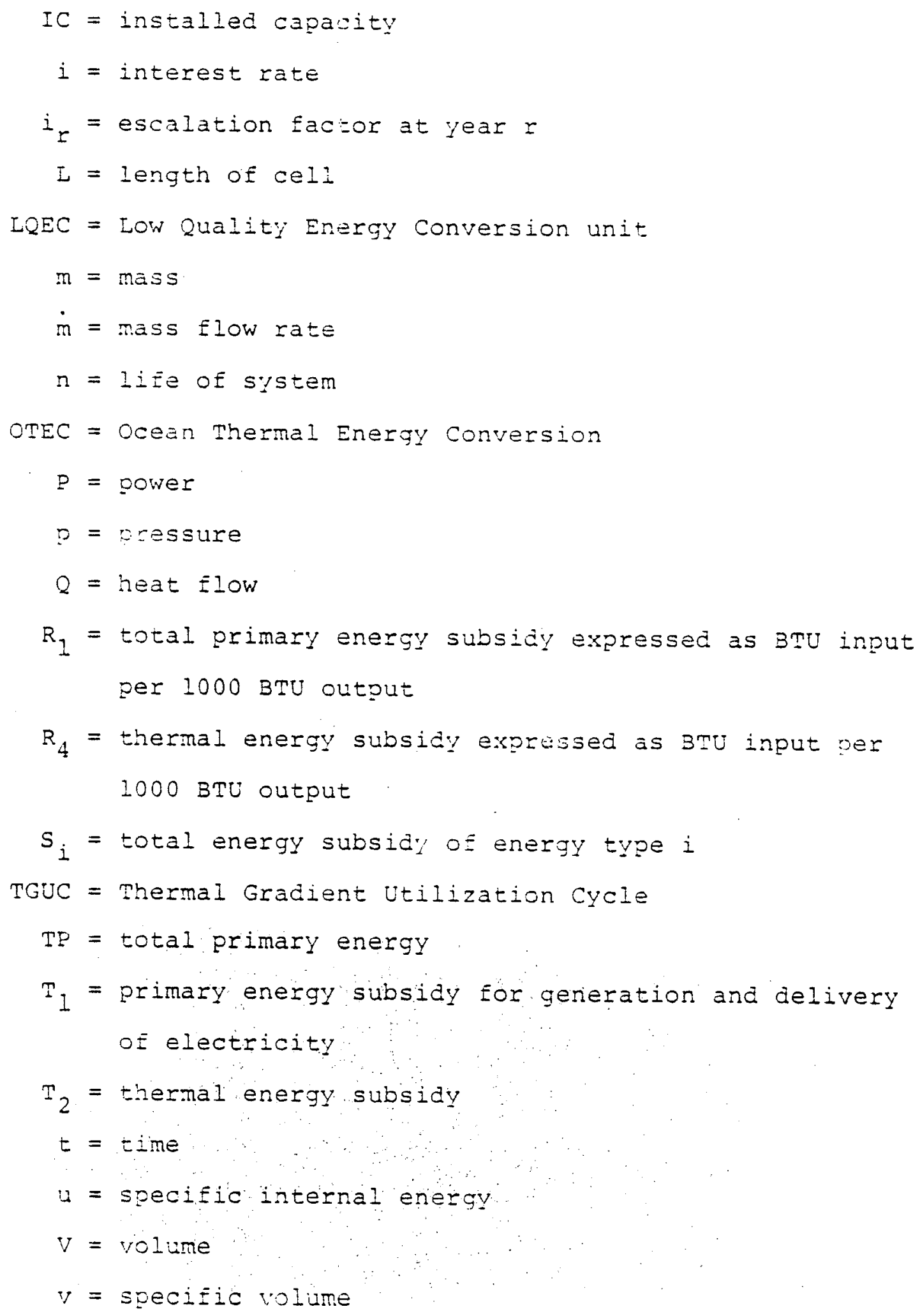




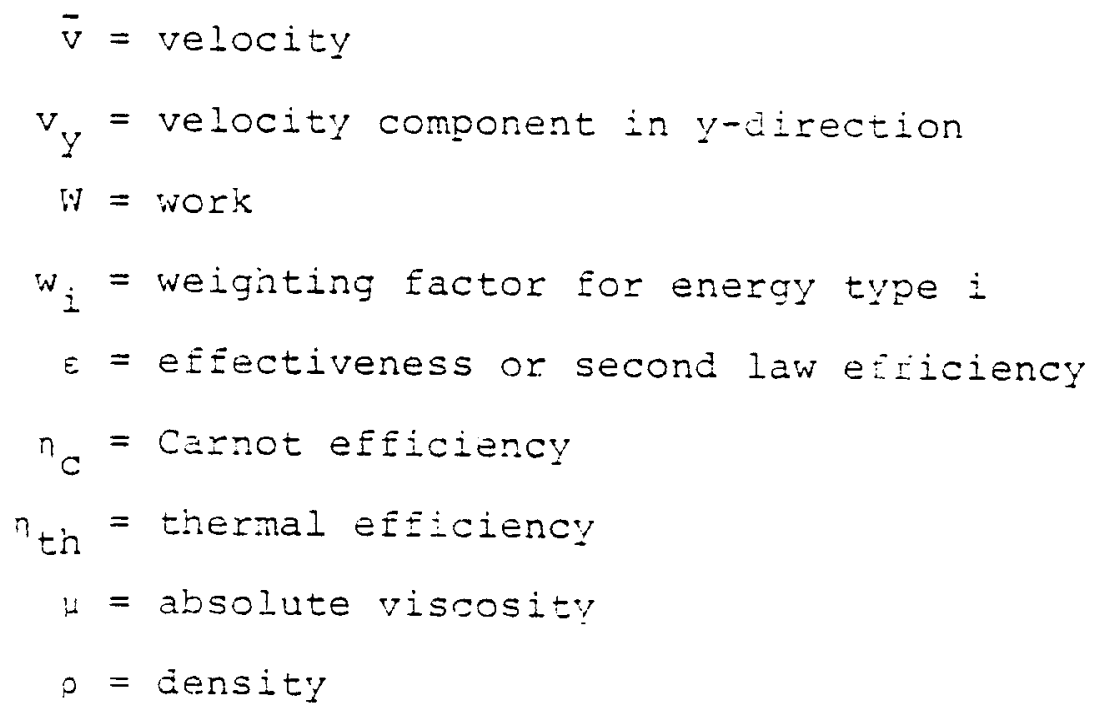




\section{INTRODUCTION}

With the advent of the OPEC Oil embargo of 1973 and subsequent escalation of oil prices, increasing attentior has been directed toward the development of alternate energy supplies and diversificatin of power production technologies. In particular, interest has grown in energy technologies that use renewable resources such as solar (thermal conversion, ocean thermal energy conversion, photovoltaics, wind and biomass convecsion), geothermal and magnetohydrodynamics (MHD).

A new concept that can be used to exploit solar, geothermal or other low grade energy sources is to utilize the temperature gradient that naturally occurs in the atmosphere to provide the temperature differential for a power production cycle. This concept known as the Thermal Gradient Utilization Cycle (TGUC) was proposed by Parker [I] in 1976 .

The basic principle of operation of the TGUC is the use of an energy source to vaporize a working fluid which then rises (vapor pressure pumped) to a higher elevation resulting in an increase in its potential energy. The working fluid is then condensed by virtue of the lower ambient air temperature at higher altitudes. The cycle is completed by

Numbers in brackets designate references at the end of the paper, which Eoliows the style di the ASYE Journal of Heat rrans Eer. 
allowing the condensed liquid to pass through a turbine as it returns to the lower elevation, thus converting the gravitational potential energy of the fluid to output power. The objectives of this investigation were to determine if the cyc... is technically feasible and whether a Thermal Grajent Utilization Cycle power plant can generate power economicaliy in terms of actual dollar costs and "energy costs.

Specifically, the following guastions were didressed:

(a) Can the system ictually deliver net power?

(b) What are the relationships between the power delivered and the various operating parameters?

(c) What is the installed cost (Dollars per kilowatt) and the busbar cost of electricity (Mills per kilowatt-hour) of a TGUC system?

(d) Over the life of a TGUC power plant, is the system capable of delivering more energy than it took to build and operate it?. i.e. Does the system have a positive net energy?

A digital computer model of the TGUC was developed and used to determine the sensitivity of the system power output to the various operating variables. The system was simulated subject to various conditions of location, working fluid, atmospheric conations, size of pipes, etc. in order to define an optimum system configuration.

The economic feasibility of the TGUC system was aecer- 
mined by the application of life cycle cost analysis to the technically optimum configuration. Net energy analysis was also applied to the TGUC system in order to determine the "energy cost" of a TGUC power plant.

The technical description and analysis, the economic analysis and the net energy analysis of the TGUC are presented in subsequent sections. Finally, the conclusions drawn from this investigation are sununarized. 
TECHNICAL DESCRIPTION AND ANALYSIS OF THE THERMAL GRSDIENT UTILIZATION CYCIE

The Thermal Gradient Utilization Cycle was devised to exploit the natural temperature gradient of the atmosphere for power production. A low gride energy source is used to vaporize a fluid which rises naturally (vapor pressure pumped) to a higher elevation where it condenses by virtue of the lower ambient air temperature. The cycle is completed by allowing the liquid to pass through a hydro primenover as it returns to the lower elevation, thus producing power.

As there are several variables important to the performance optinization, a parametric study was conducted to determine the effects of some of these parameters on the power output. In order to simulite an actual TGUC system, a specific location had to be selected, thus fixing some variables (elevation, temperature gradient, temperature of the heat source and wind speed), and facilitating capital cost estimation for the economic analysis.

Thermal Gradient Utilization Cycle systems can be classified into two basic categories; Atnospheric Thermal Gradient Cycles (ATGC) which utilize the atmosphere as heat sources, and Low Quality Energy Conversion units (IQEC) which use low grade energy (geothermal, solar ponds, etc.) to vaporize the working fluid.

The following sections describe the operating 
principles of the Tor.., the digital computer model, the Atmospheri- Therma: Cadient Cycie, the parametric study, and finally, the Low juality Energy Conversi n Unit.

\section{Operating Princinles}

The purpose of this section is to present the physical principles upon which the Thermal Gradient Utilization Cycle is based. An overview of the TGUC operation is given, and vapor prejsure pumping and the method of power generation using a hydraulic head are explained. "inally, the requirements for site selection are presentea.

Fig. I is a schematic representation. of the TGUC system. Heat transfer from the energy source causes the working fluid to vaporize in the boiler and the state of the fluid changes from 1 to 2 as shown in Eigs. 2 and 3. The vapor then rises up the vapor pipe (state 2 to 3) as the pressure decreases. The change in state from 2 to 3 may be accompanied by an increase or decrease in entropy depending on the amount of heat transferred from the vapor pipe to the atmosphere.

If the thickness of the insulation on the vapor pioe is sufficient so that the flow is adiabatic, the stagnation enthalpy will remain constant, the pressure will decrease due to fluid friction, and the process will follow a Fanno line [2 resulting in an increas in fluid velocity and a slight increase in temperature (state $3^{\prime \prime}$ ). If heat transfer 


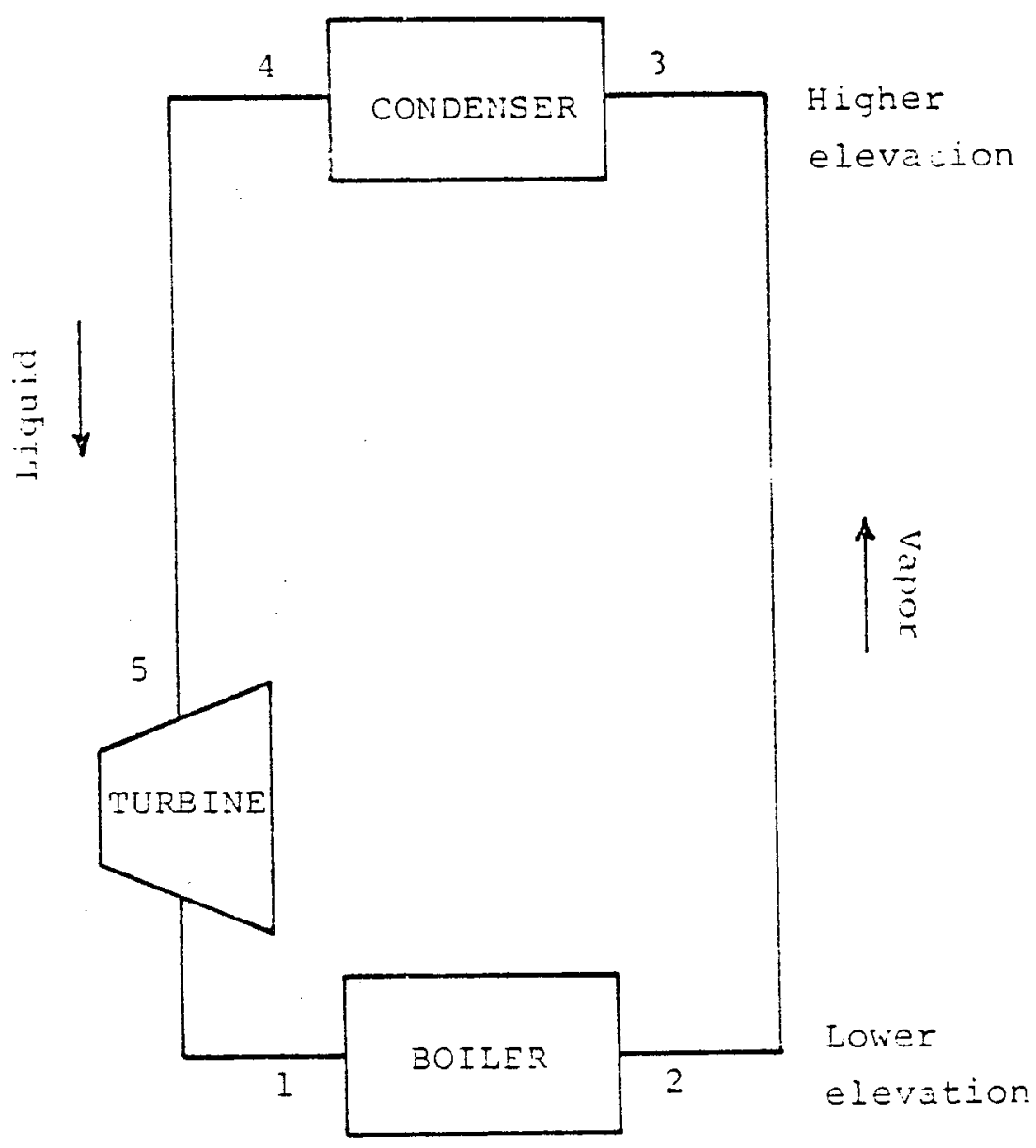

Eig. I Schematic diagram of the Thermal Gradient Utilization cycle 


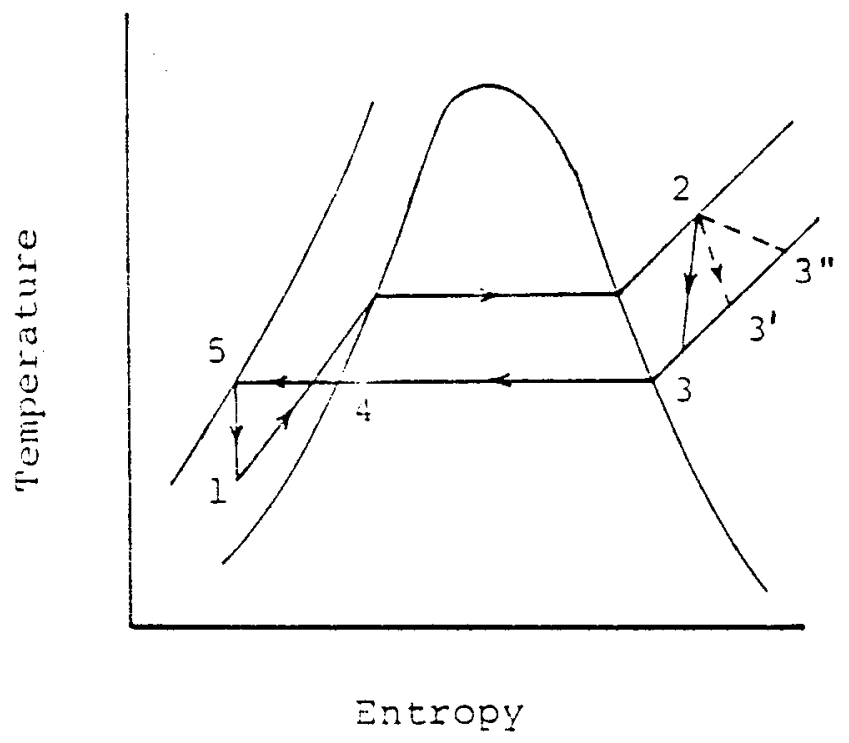

Pig. 2 Temperature-ritropy diagram of the Thermal Gradient Utilization Cycle

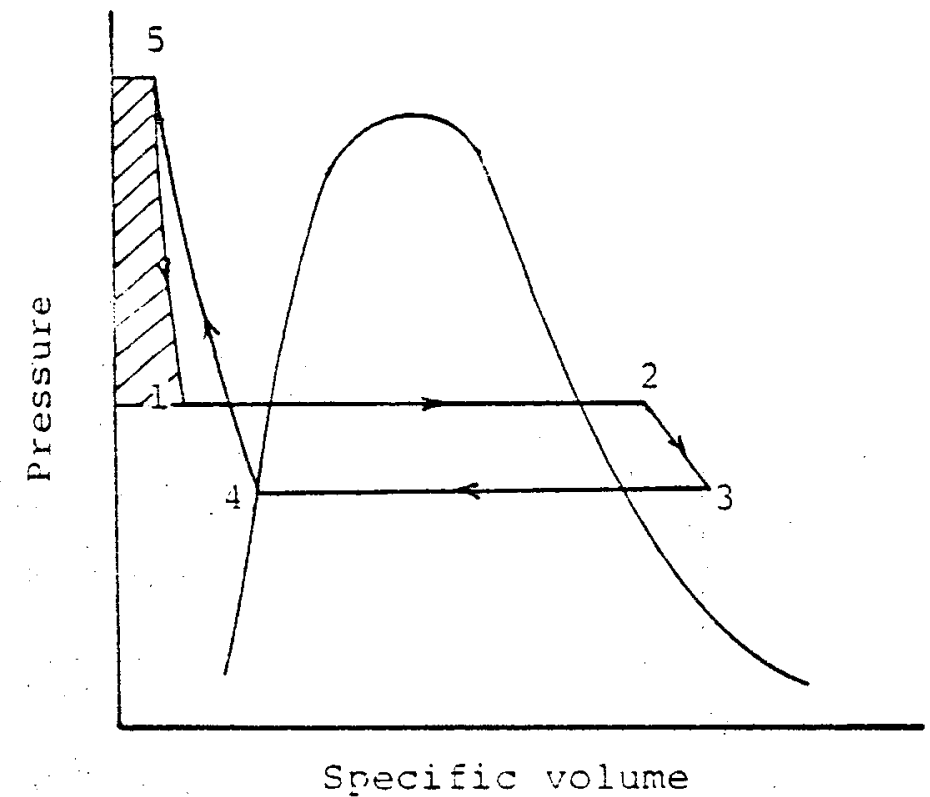

Eig. 3 Pressure-specific volume diagram of the Thermal Gradient Utilization Cy:le 
from the fluid to the atmosphere takes place, the temperature could decrease further (state $3^{\prime}$ ) or even result in a decrease in entropy (state 3 ).

In order to raise the fluid to a higher elevation, low quality heat is used in a phenomenon known as vapor pressure pumping which resembles the phenomenon occuring in a teapot. Since the specific volume of steam is greater than that of water, the steam fills the teapot and eventually escapes through the spout. An accurate analogy can be drawn between the TGUC's boiler and the teapot, and between the TGUC's vapor pipe and the spout. Vapor will rise up the vapor pipe as long as the liquid is being vaporized by the addition of heat in the boiler. The continuous formation of vapor forces the vapor up the pipe resulting in a higher pressure at state 2 than at state 3 . This pressure differential is due to the weight of the column of vapor and the Erictional head loss due to the flow of the vapor.

The work needed to raise the fluid to a higher elevation is equal to the work done against gravity and the work done against friction. The energy required to do this work is equal to the heat transferred to the working fluid in the boiler minus the heat transferred from the vapor pipe and condensor to the atmosphere. The phenomenon of vapor pressure pumping enables the potential energy of the working fluid to be raised. using low quality energy from the surroundings. 
The working fluid is then condensed (state 3 to 4 ) at the higher elevation. As the liquid flows down to the turbine it gets compressed due to the weight of the licuid column. When the liquid is allowed to flow through the turbine, the power generated is directly proportional to the height of the head, the mass flow rate of the liquid and the density of the fluid. The work obtained from the cycle is proportional to the shaded area in Fig. 3 (n. 7).

In order to utilize these principles, not only does the equipment have to be properly designed, but the plant site must be carefully selected. There are two specific site requirements for the cycle to operate. There must be a large and steep change in elevation in the topography along with a large heat source (not necessarily high temperature) at the lower elevation and a correspondingly large heat sink at the upper elevation.

\section{TGUC Computer Model}

A computer model of the Thermal Gradient Utilization Cycle was developea to determine the technical feasibility of the cycle, and to study the effects of system parameters on the performance of the cycle The vapor and liquid pipes required the most extensive modelling due to the effects of heat transfer rates and fluid friction, and the presence of a condensable vapor in the vapor pipe. The heat exchangers (boiler and condenser) and turbine were modelled using 
simple thermodynamic relationships.

The model for fluid flow in the pipes consists of a series of cells as shown in Fig. 4. For the steady state case, the mass fluxes across each of the cell boundaries are equal. Thus the change in energy, momentum and mass in each cell is zero.

The mathematical relationships modelling the flow were derived from basic principles, i.e. momentum and energy balances on a control volume. The detailed development of the equations of flow are presented in Appendix A. For a one-dimensional case the momentum and energy equations are

$$
\begin{gathered}
\frac{\partial G}{\partial t}=-2 G v \frac{\partial G}{\partial y}-G^{2} \frac{\partial V}{\partial Y}-\frac{\partial p}{\partial Y}-\frac{F}{V}-\frac{n g}{V} \\
\frac{\partial q}{\partial t}=\frac{\partial}{\partial t}(m u)+V \frac{\partial}{\partial Y}(G e)-G v\left(V \frac{\partial p}{\partial Y}+F_{S}+m g\right)+\frac{\partial W}{\partial t}
\end{gathered}
$$

where

$$
\begin{aligned}
& G \text { - mass flux, } \mathrm{kg} / \mathrm{m}^{2} \mathrm{~s} \\
& t \text { - time, } \mathrm{s} \\
& \mathrm{v} \text { - specific volume, } \mathrm{m}^{3} / \mathrm{kg} \\
& \mathrm{p} \text { - pressure, Pa, } \\
& \mathrm{F} \text { - Erictional force, } \mathrm{N} \\
& \mathrm{m} \text { - mass of fluid in control volume, } \mathrm{kg} \\
& \mathrm{g} \text { - acceleration due to gravity, } \mathrm{m} / \mathrm{s}^{2} \\
& \mathrm{~V} \text { - volume of cell, } \mathrm{m}^{3} \\
& q \text { - heat flow, J }
\end{aligned}
$$




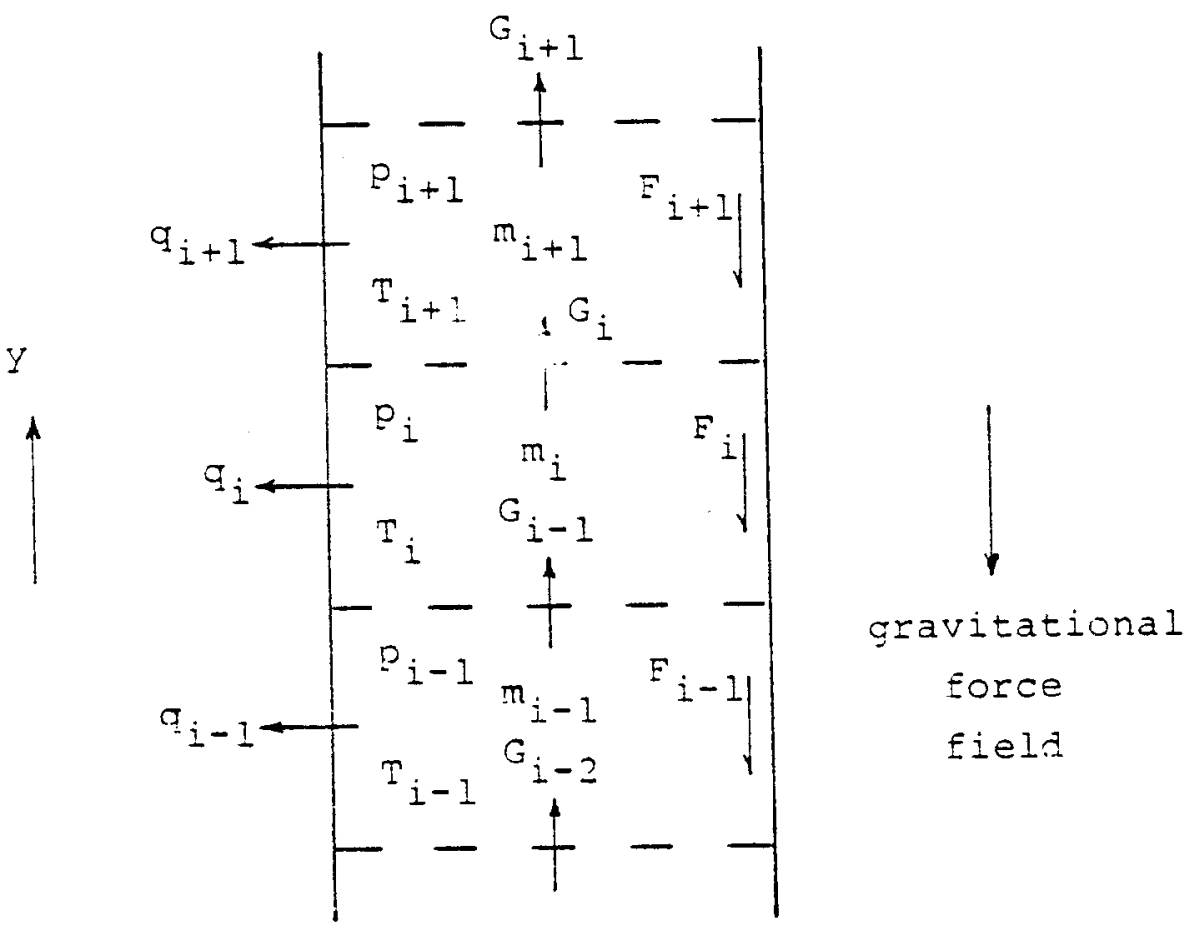

Fig. 4 Computational model for flow in TGuC vapor pipe 


$$
\begin{aligned}
& \mathrm{u} \text { - specific internal energy, J/kg } \\
& \text { e - specific enthalpy, J/kg } \\
& \text { W - work done on control volume, J }
\end{aligned}
$$

The frictional force on the control volume, $F_{S}$ is given by the expression [3]

$$
F_{S}=\frac{2 E_{\mu G V}}{\rho d^{2}}
$$

where

$$
\begin{aligned}
& \text { - Fanning friction factor } \\
& \mu \text { - absolute viscosity, Ns } / \mathrm{m}^{2} \\
& \text { a - pipe diameter, } \mathrm{m}
\end{aligned}
$$

The time dependent solutions to these equations were obtained by using the fourth order Runge-kutta technique [4]. Spatial derivatives were determined by a single step upwind differencing technique. For the computational model shown in Fig. 4 (p. 11) the derivatives were calculated as

$$
\frac{d x}{d y}=\frac{x_{i}-x_{i-1}}{L}
$$

where $x$ is a variable in the system ascribed to a cell and I is the length of the cell. This is an initial value problem which integrates forward in time until equilibrium is reached. However, since transients during the system startup did not reveal any uncertainties, the simulation can be effectively carried out at steady state. 
At equilibrium, the flow is time independent and mass fluxes across each of the cell boundaries are equal. Thus, the momentum and energy equations reduce to

$$
\begin{gathered}
G^{2} \frac{d v}{d y}+\frac{d p}{d y}+\frac{E s}{v}+\frac{m g}{v}=0 \\
V \frac{d}{d y}(G e)=\frac{G}{p}\left(\frac{V d p}{d y}+E_{s}+m g\right)+\dot{q}
\end{gathered}
$$

where

$\dot{q}$ - rate of heat flow, J/S

In this system, the kinetic energy of the fluid is considered to be negligible. Thus, equations (5) and (6) can be further simplified to

$$
\begin{gathered}
\frac{d \underline{p}}{d y}=-\left[\frac{F}{V}+\frac{m q}{V}\right] \\
\dot{q}=V \frac{d}{d y}(G e)
\end{gathered}
$$

The pressure and temperature distributions of the fluid along the length of the pipes were determined by numerically solving the simplified momentum and energy equations. The fluid properties in each successive downstream cell were determined from the properties in the upstream cell after subtracting the losses due to friction and heat transfer occuring during the time it takes for the Fluid to travel through the cell. Since the properties of the fluid are known at the boiler and condenser exits, the 
fluid properties in each cell could be determined. However, since the energy losses affect the temperature $0:$ the working fluid which in turn affects the viscosity and heat transfer rate, the solution for each cell was obtained by iteration until convergence criteria were met.

The heat exchangers (boiler and condenser) were represented as assigned heat gains and losses to the fluid with no pressure drop. The turbine power output was calculated using the equation:

$$
P=\frac{\dot{m} \Delta p}{\rho}
$$

where

$$
\begin{aligned}
& p \text { - power output, } w \\
& \dot{\mathrm{m}} \text { - mass flow rate of the liquid, } \mathrm{kg} / \mathrm{s} \\
& \Delta p \text { - pressure drop across turbine, } \mathrm{pa} \\
& p \text { - density of the liquid, } \mathrm{kg} / \mathrm{m}^{3}
\end{aligned}
$$

A flow chart and listing of the computer code is shown in Appendix $C$.

\section{Atmospheric Thermal Gradient System}

The following is a discussion of the Atmospheric Thermal Gradient System operating characteristics and the selection of a hypothetical plant site. The dimensions for a 10 megawat power plant for the specific site are presented and criteria for the selection of a working fluid are explained. 
As outlined previously, all TGUC systems require a heat source and sink, and utilize the principle of vapor pressure pumping to operate. In the case of the Atmospheric Thermal Gradient Cycle (ATGC), the atmosphere is used as the energy source and sink. The temperature gradient necessary for the ATGC's operation is derived from the natural thermal gradients ciat exist at all times except when temperature inversions in the atmosphere occur. This thermal gradient is due to solar radiation passing through the atmosphere and striking the earth which then han-

\section{ADDENDLM}

Please note that the cycle operates, as described, day or night, summer and winter.

The cycle is totally self adjusting and as stated only requires the $\Delta \mathrm{T}$. The ammonia vapor curve readjusts up and down to tit the ambient temperature.

-- .u lunger being heated

by the sun's radiation, the earth continues to heat the layer of air adjacent to it with thermal energy stored during the day. Even if the temperature at the lower elevation drops, the temperature gradient remains constant since the ambient air temperature also drops at the higher altitude. As the ambient air temperature fells, the pressure in the vapor pipe will automatically arop to compensate for the decrease in temperature. Thus, the system will continue to generate the same amount of power as it did during the day. Thus, the earth acts as the collector and storage unit of this solar ariven system and the 
atmosphere is the heat transfer medium.

The prime requirement of a potential site for an ATGC power plant is a large and steep change in elevation. For a given flow rate of the working Eluid, the power output increases with an increase in elevation. For this investigation, Palm Springs, California was selected as a potential site for a TGUC power plant. Mount San Jacinto rises 10,000 feet from the dry desert floor providing a temperature difference of $40^{\circ} \mathrm{F}$ between the lower and upper elevations. Secalise of the ideal environmental conditions at Palm Springs, it was felt that if it were not technically and economically feasible to operate a TGUC power plant there, it would preclude the feasibility at any other site. In selecting an actual plant site, the political and environmental impacts would have to carefully considered. These considerations, however, are beyond the scope of this investigation.

System Components

A 10 megawatt TGUC system was designed for the Palm springs application. Three hydraulic turbines rere cascaded in the liquid pipe in order to limit the pressure drop across a turhine to 800 psi. This was necessary since vendors were unable to supply a turbine that could accommodate a pressure of 2,500 psi present at the bottom of a 3,000 meter uncascaded liquid line. The configuration of 
the Palm Springs TGUC system is shown in Fig. 5. The boiler and condenser are heat kxchangers of virtually the same capacity. The folloring heat exchanger specifications were provided by a heat exchanger manufacturer:

(a) $2.3 \times 10^{5}$ square feet each, 2 required.

(b) 3 row, 3 pass.

(c) $5 / 8$ inch diameter steel tubes.

(d) 1/16 inch tube wall thickness.

(e) $1 / 64$ inch Aluminum Eins.

(f) Circular fins protruaing $7 / 16$ inch from the tube.

(g) 20 fins per inch.

(h) Tubes spaced at 1.5 inch centers.

(i) Designed for a 5 mph winl speed-

Selection of a Working fluid

The selection of an optimum working fluid is critical to the system operation and power output due to the small temperature differential. Consider the following factors:

(a) Power output is a function of mass flow rate, pressure drop across the turbine, and the fluid density.

(b) The difference in pressure between the inlet and outlet of the vapor pipe is due to the weight of the vapor (gravitational force) and the frictional pressure drop die to flow (see equation 7 ), i.e. it is a function of the varor density and velocity. The frictional effect is negligible compared to the gravitational ellect. Thus, 


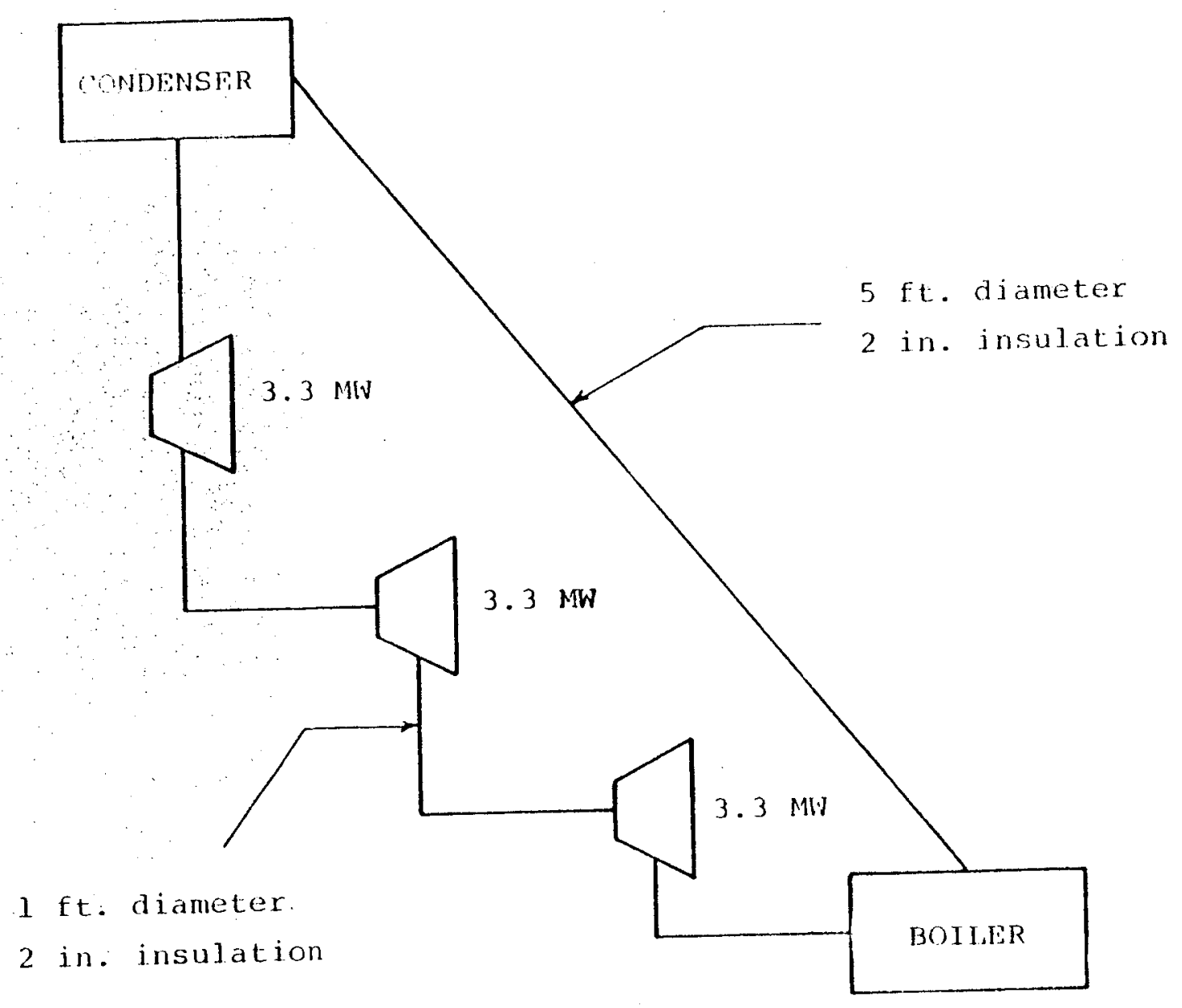

Fig. 5 Configuration of a $10 \mathrm{MW}$ Thermal Gradient Utilization Cycle power plant 
the pressure differential in the vapor pipe can be considered to be a function of only the density of the fluid.

(c) The saturation temperature at which the liquid vaporizes or vapor condenses is dependent on the pressure. The lower the pressure, the lower is the saturation temperature. There must be a temperature difference between the fluid and the atmosphere for heat transfer to take place, i.e. the temperature of the heat source must be greater than the saturation temperature of the liquid in the boiler, and at the condenser, the ambient air tem:erature must be lower than the saturation temperature of the working Fluid.

In an attempt to maximize the power output for an ATGC, a dense working fluid was initially selected. Dense fluids such as freons have high molecular weights [5]. The saturation temperatures of a typical freon as a function of elevation are shown in Eig. 6. As the freon vapor rises up the vapor pipe, the pressure decreases due to a shorter vapor column above it, resulting in a decrease in saturation temperature. For Atmospheric Thermal Gradient systems, the saturation temperature of high molecular weight fluids never increases above the ambient air temperature at the higher elevation, and therefore, condensation can never take place. If a high temperature heat source is usec, almost all freons could be used in a TGUC system. For ATGC systems, low molecular weight fluids must be 


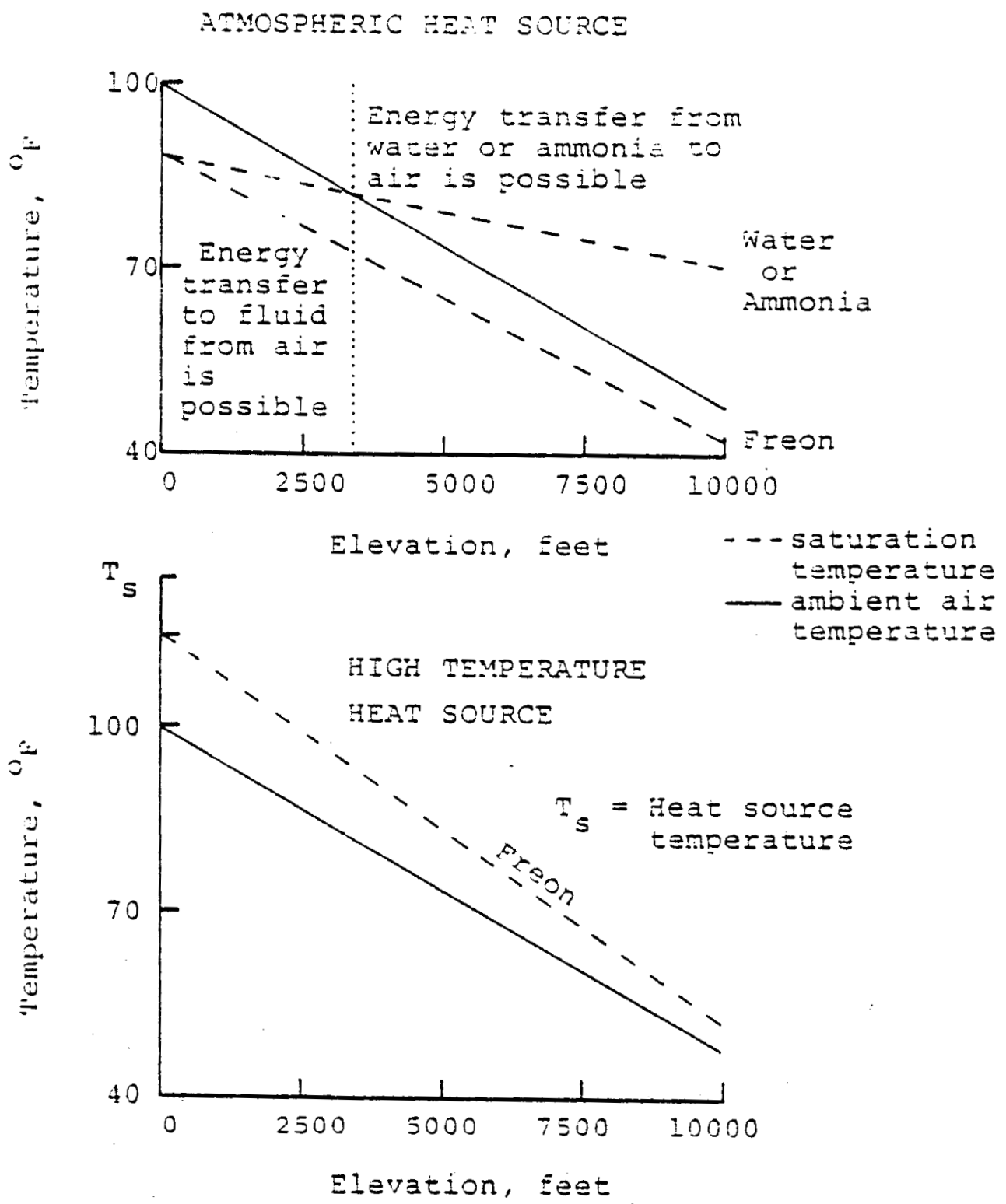

Note: The temperatures indicated on the atnospheric heat source ciagram are representative of the system analyzed in this investigation. If the amoient air temperatuzes change, the working Fluid saturation temperatures would have to ta changed by aporopriately changing the pressure of the vapor in the boilez, resulting in an upward or downward shift of tre curves, and allowing heat transfer from the air to the Eluid in the boiler and Erom the Eluid to the air in the condensez.

$$
\text { Eig. } 6 \text { Effact of eiavazion on sazuration temperatura }
$$


used. Water and ammonia were the only commor fluids with molecular weights low enough to allow them to condense in the ATGC after being flashed to vapor at low pressures and temperatures in the boiler.

water at $90^{\circ} \mathrm{F}$ is much less dense than ammonia vapor at $90 \mathrm{~F}$ [5]. In order to minimize the pressure arop in the vapor pipe for water Elowing at a rate sufficient to generate 10 megawatts of power, the vapor pipe would have to be approximately 50 feet in diameter. On the other hand, the diameter of the vapor pipe would have to be approximately 5 feet if ammonia were used in the ATGC. Thus, based on a lower capital cost of the vapor pipe, ammonia was selected as the working fluid.

\section{Parametric Study}

Parameters affecting the operation of the TGUC system were varied to determine their effect on the power output. A number of parameters, when varied, did not significantly affect the power output after a certain limit was reached. The second group of parameters had a significant effect on snwer output, and included temperature gradient, mass flow rate and elevation.

The effect of pipe size on the power output is shown in Fig. 7. A change in the size of the vapor pipe used results in a change in pressure drop. As the pressure drop increases; the saturation temperature of the working fluid 


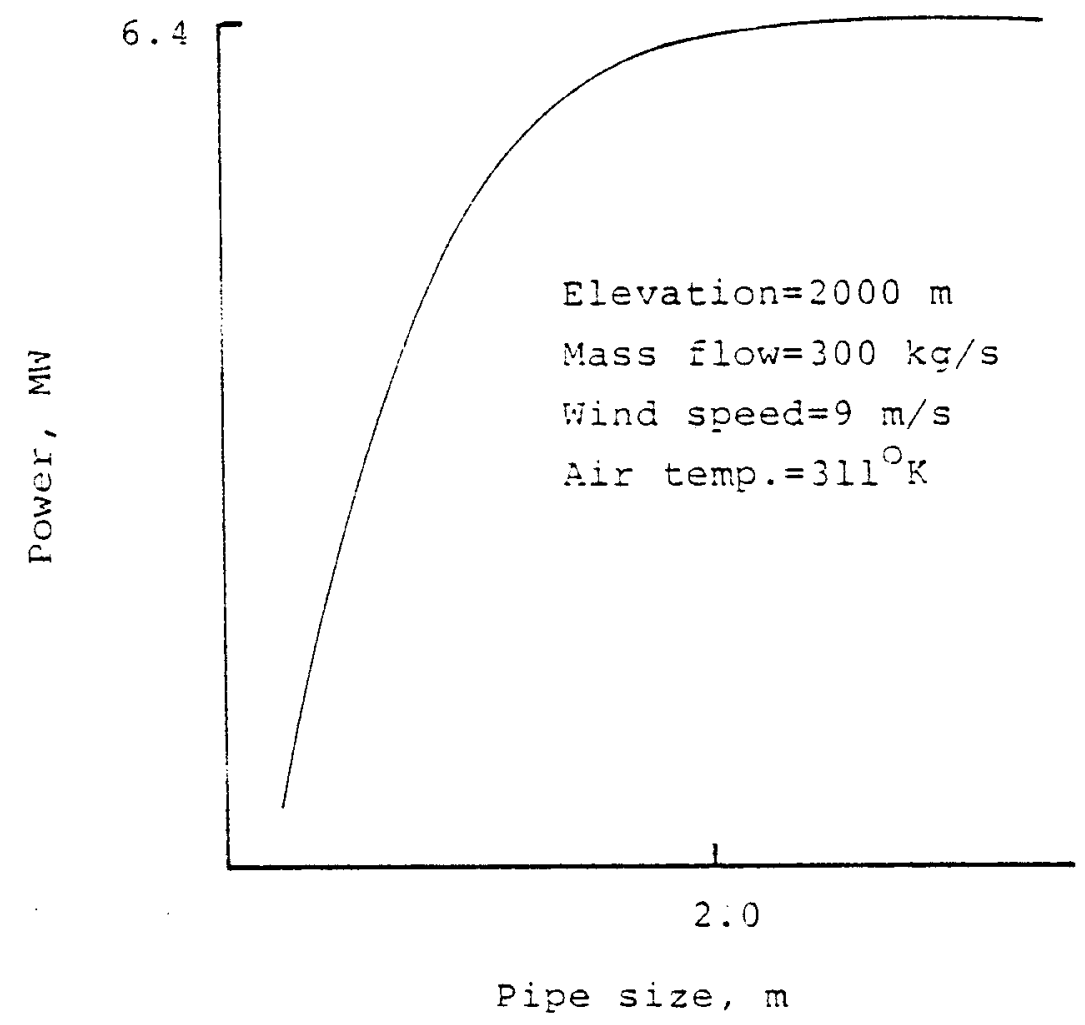

Fig. 7 Effect of pipe size on power output 
decreases, which in turn cecreases the capacity of the condenser. However, by increasing the pipe size beyond a certain limit, the pressure drop due to fluid flow becomes negligible compared to the pressure drop due to the column of the working fluid.

The effect of temperature gradient on the power output S shown in Fig. 8. Small changes in the temperature gradient s gnificantly affect the power output. As the ambient as temperature at the nigher elevation increases due to a decreasing temperature gradient, the air temperature approaches the fluid saturation temperature and rapidiy reduces the condenser capacity to zero.

The thickness of the insulation on the vapor pipe is critical to the operation of a TGUC system. As condensate forms in the vapor pipe due to an inadequate insulation thickness, the capacity of the system will be reduced. If only slight condensation occurs, the liquid aroplets will be entrained in the vapor stream and carried on to the condenser. If conaensation in the vapor pipe is al owed to increase, the system will stop producing power. The effect of the thickness of insulation on power output is shown in Eig. 9 .

Variations in the elevation and mass flow rate affect the fower output to a large degree. The effect of these parameters are shown in Eigs. 10 and 11. The elevation can increase indefinitely, Inited by the topography, construc- 


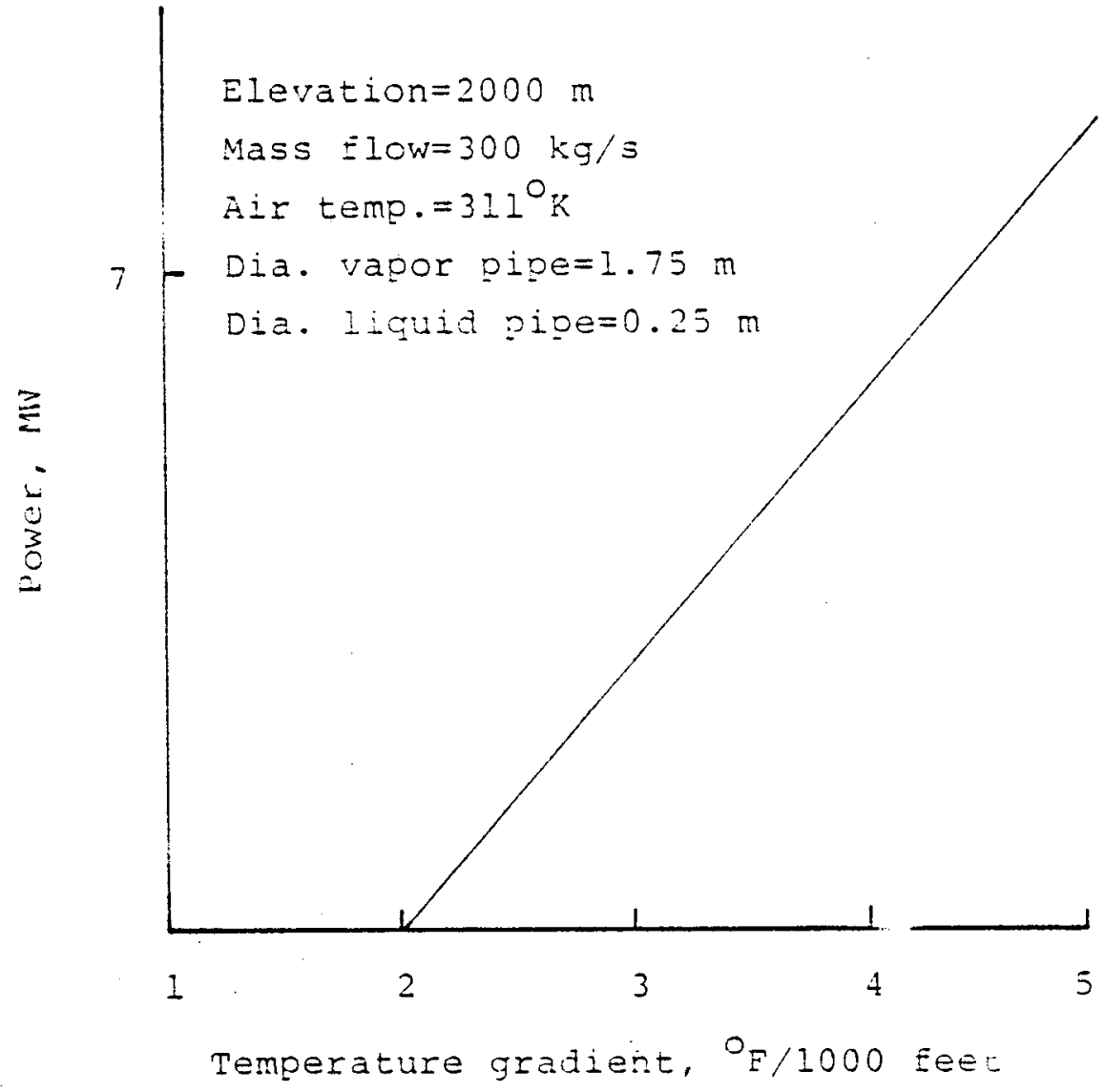

Fig. 8 Effect of temperature gradient on power output 


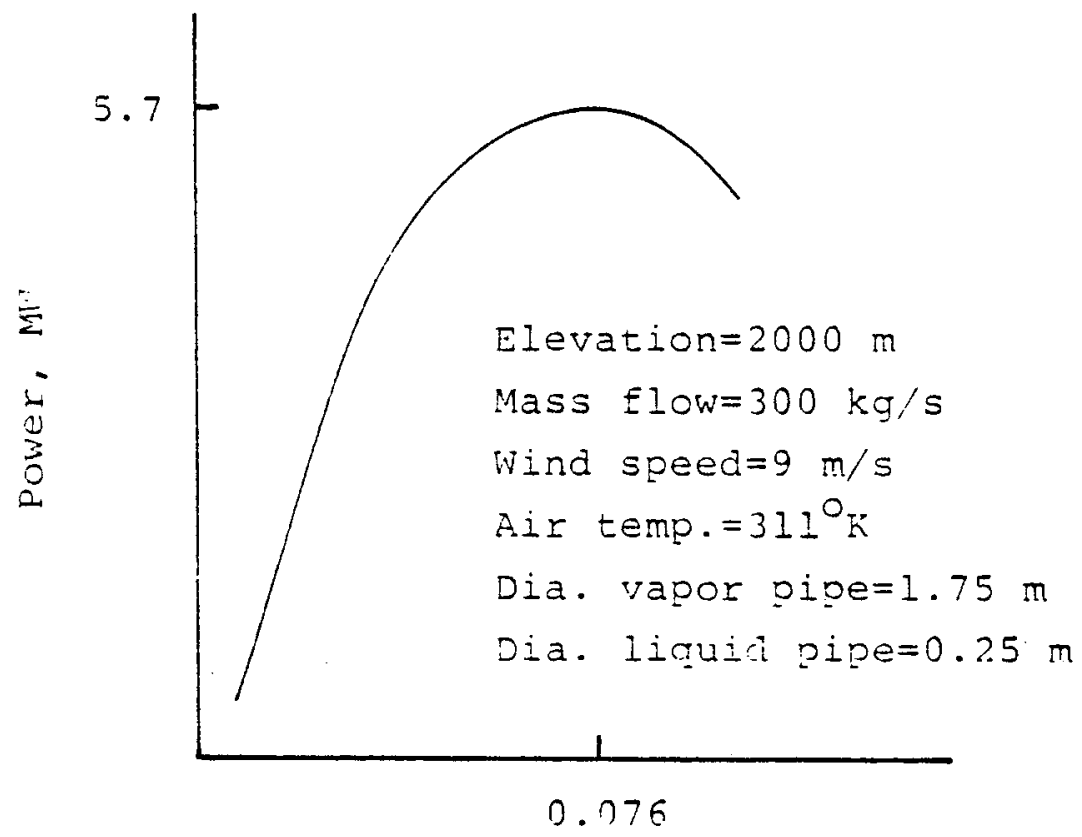

Insulation thickness, m

Eig. 9 Effect of insulation thickness on power output 


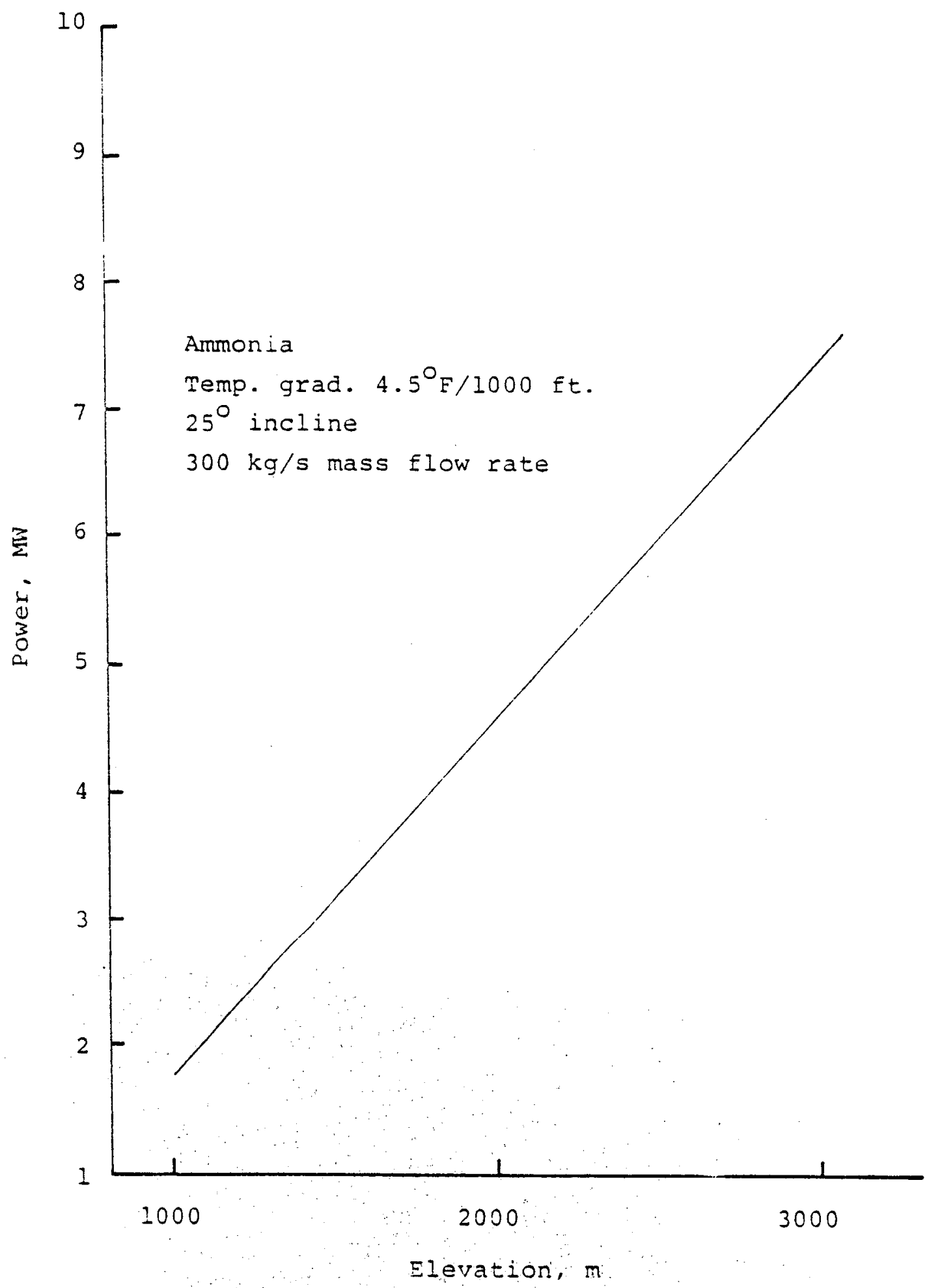

Fig. 10 Effect of elevation on power output 


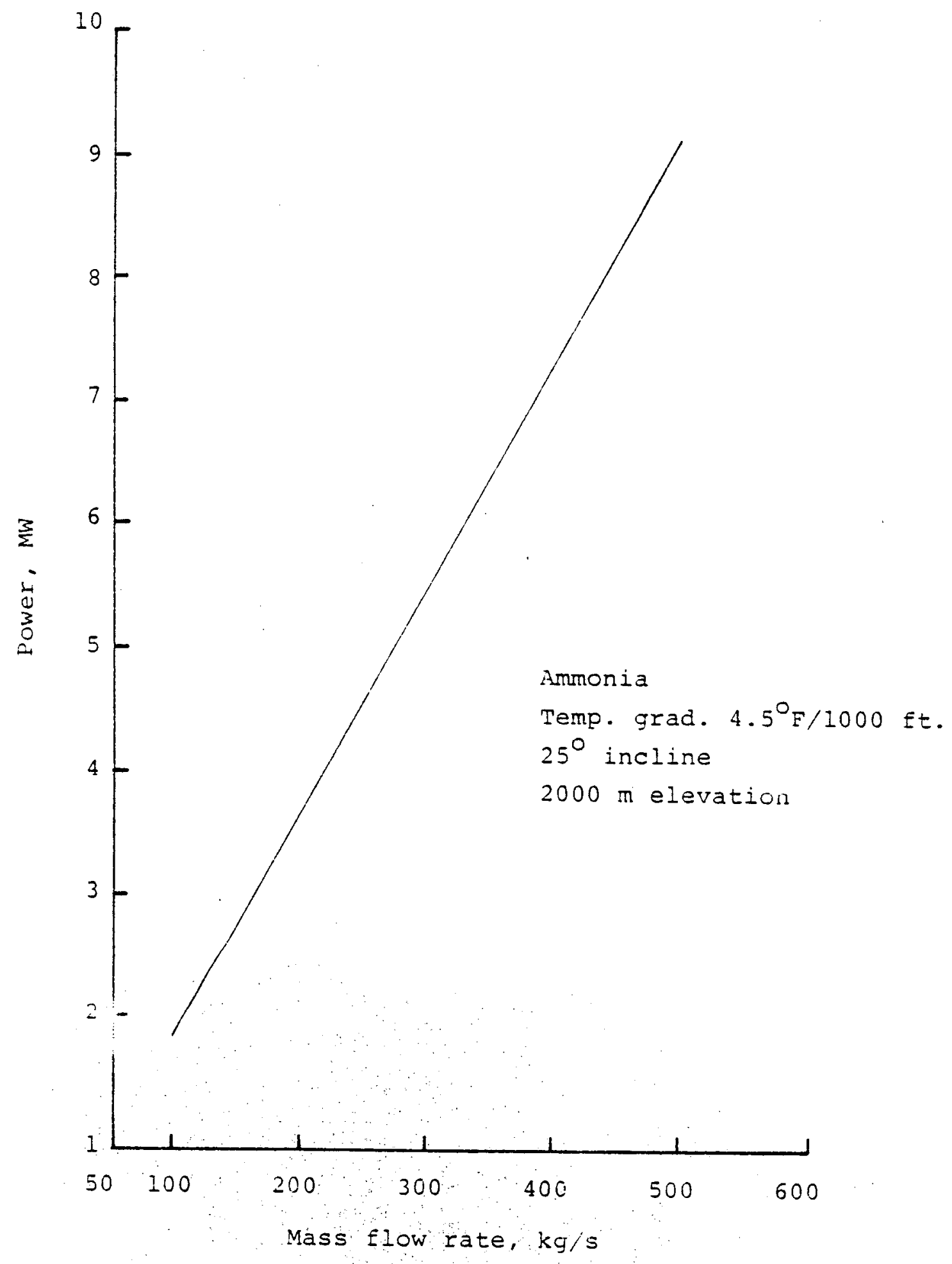

Fig. Il Effect of mass flow rate on power output 
tion costs and the avalas.ity ot materials. On the other hand, the mass flow rate ari increase up to a point where the pressure drop causes the saturation temperature of the Eluid to arop below the ambient air temperature at the upper elevation, thereby making condensation impossible.

\section{Low Quality Energy Conversion Unit}

The Low Quality Energy Conversion Unit (IQEC) differs only slightly from the ATGC in that it utilizes a relatively higher temperature heat source such as industrial waste heat, geothermal energy, and energy from solar ponds.

The increased temperature gradient resulting from the higher heat source temperatures, enables the uses of high molecular weight fluids in the LQEC. The optimum fluid would be the one which provides the most power for a given pipe configuration. The power output from a TGUC system is given by

$$
\mathrm{P}=\frac{\dot{\mathrm{m}} \Delta \mathrm{P}}{\mathrm{p}}
$$

The pressure drop across the turbine is given by

$$
\Delta p=\rho g h
$$

Thus, equation $(10)$ can be simplified to

$$
P=\dot{m} g h
$$


Thus, for a particular elevation, $h$, the power cutput is a function of the mass flow rate. The mass flow rate, on the other hand, is a function of the density of the fluid, the flow velocity, and the area of cross section of the pipe.

The amount of flow that can be established in the vapor pipe determines the mass flow rate in the system land thus through the turbine) since the fluid density is the lowest there. Thus, for a particular system configuration, the fluid with the densest saturated vapor will maximize the power output.

In selecting a TGUC system that would be feasible, the Low Quality Energy Conversion Unit did not appear attractive. A geothermal application seemed to be the most direct way of utilizing the TGUC effectively. Of the few geothermal well locations existing, geothermal steam flow rates were found to be insufficient to provide adequate energy transfer rates to vaporize the working fluid at the flow rate necessary to generate a substantial amount of power. 
ECONOMIC ANALYSIS

The previous phase of this research provided a design configuration for a 10 megawatt TGUC system, on which the economic analysis is based. The prime objective of this phase is to estimate the installed cost (dollars per kilowatt) and the busbar cost of electricity (Mills per kilowatt-hour) of the TGUC power plant. Although the economic analysis is restricted to this case study, it appears that the cost of power generation ( $\$ / \mathrm{kW}$ and Mills/kWh) will be typical of all TGUC power plants.

Two approaches to the economic analysis were taken. The first approach [6] is the procedure generally used in power generation cost evaluation, and therefore provides a basis for comparison for TGUC and other power production technologies. The second approach, Iife cycle cost analysis, is a more realistic estimation of power generation costs. The procedure for calculating the power generation costs by both methods is detailed in Appendix $D$.

The customary method used for economic analyses of power production systems does not consider equioment replacement, and assumes that operation and maintenance costs (and fuel costs if applicable) remain constant over the projected life of the system. In view of these drawbacks, this method is acceptable only for comparitive purposes since other studies on power generation cost estimation use this procedure. 
The life cycle cost analysis approach takes into account the time value of money and equipment replacement, as well as annual escalation in labor and material costs and interest rates, thus providing a more realistic cost analysis than the customary method.

The following sections provide a detailed description of the input costs, a discussion of life cycle cost analysis and finally, the results of the economic analysis.

\section{Cost Inputs}

Cost data for system components were obtained Erom manufacturers and vendors and include the cost of delivery and installation at the plant site. Table 1 sumarizes the cost data in constant 1979 dollars and represent first unit costs.

Capitalization costs

The Thermal Gradient Utilization Cycle is a new concept in power generation and has relatively high investment costs. Thus, before it can draw support from private investors it appears that initially the federal government may have to support its financing. The concept of initial Eederal government financial support has precedence, namely in the public utility and airline industry... several probable finaricing schemes for a TGUC power plant are presented in Table 2. The annual Eized charges for a TGUC 
Table 1 Construction costs of a 10 MW baseline TGUC system in constant 1979 dollars

\begin{tabular}{lc} 
Component & $\begin{array}{c}\text { First unit cost } \\
10^{6} \text { dollars }\end{array}$ \\
\hline Heat exchangers & 20.0 \\
Turbines and generator & 5.0 \\
Electricals & 0.8 \\
Pipes & 3.0 \\
Ammonia inventory & 0.5 \\
Polyurethane insulation & 1.0 \\
Miscellaneous & 0.5 \\
\hline
\end{tabular}




\section{Table 2 Financing schemes}

\section{Breakdown Interest Effective}

Source of Eunds, \% rate, \% interest rate, \%*
(A) Federal
100
7.0
7.0

(B) Federal

50

7.0

Tax-exempt

bonds

50

7.5

8.0

(C) Eederal

35

7.0

Tax-exempt

bonds

50

8.0

8.7

stock issue

15

15.0

(D) Federal

Tax-exempt

bonds

stock issue
25

7.0

50

8.0

25
9.5

*Effective interest rate is a weighted average of the interest rates of the various sources of funding for each scheme. 
power plant Einanced in various ways are presented in Table 3. The cost of money was taken from Table 2 in computing the fixed charges.

Deferred construction costs were estimated to be 0.67 percent over a two year construction period. In the case of complete federal government financing, depreciation, taxes and insurance were not considered [7]. Insurance for public owned systems were estimated at 0.8 percent and taxes at 0.6 percent. Depreciation was calculated using the sinking Eund method [8] for a plant life of 50 years.

Annual Operation and Maintenance Costs

Due to similarities in the operation of Ocean Thermal Energy Conversion (OTEC) systems and TGUC systems, the annual cost of operation and maintenance was estimated to be 1.46 Mills per kilowatt-hour which is approximately 75 percent of the estimated operation and naintenance costs of an OTEC system [9]. This estimate can be justified since service ships and dockyard facility costs do not apply to TGUC systems.

\section{Life Cycle cost Analysis}

In studying the economic feasibility of any venture, Eive factors stand out as requiring careful consideration.

(a) Initial capital investment cost

(b) Annual operation and maintenance costs 
Table 3 Average annual fixed charges as a percentage of total investment for a rGUC power plant

\begin{tabular}{|c|c|c|c|c|}
\hline Breakdown & (A) & $\begin{array}{c}e \text { of } \\
\text { (B) }\end{array}$ & $\begin{array}{l}\text { ancing* } \\
\text { (c) }\end{array}$ & (D) \\
\hline Interest & 7.0 & 7.5 & 8.7 & 9.5 \\
\hline $\begin{array}{l}\text { Deferred } \\
\text { construction cost }\end{array}$ & 0.67 & 0.67 & 0.67 & 0.67 \\
\hline Insurance & 0.0 & 0.8 & 0.8 & 0.8 \\
\hline Depreciation & 0.0 & 0.21 & 0.14 & 0.10 \\
\hline Taxes & 0.0 & 0.6 & 0.6 & 0.6 \\
\hline Total fixed charges & 7.67 & 9.78 & 10.91 & 11.67 \\
\hline
\end{tabular}

* See Table 2 (p. 33) for description of sources of funds. 
(c) Major repairs and equipment replacement cost

(d) Salvage values

(e) Time value of money

Iife cycle cost analysis is a method of cost evaluation which recognizes the sum of all costs associated with a venture during its projected useful life, and provides a quantitative cost index that is essential for making decisions.

It should be stressed that since the analysis data inputs are often forecasts, estimates and assumptions, it would be erroneous to carry the life cycle cost analysis to abnormally precise degrees. Life cycle cost analysis is a tool which synthesizes data and contributes to making logical decisions, but it is not an end in itself.

The purpose of analyzing investment oppurtunities is to measure the productivity of current dollar expenditures against future benefits derived from the implementation of the proposed venture. Since money can earn at a certain interest rate through its investment for a period of time, it is important to recognize that a dollar received at a Euture date is not worth as much as a dollar at the present time. This relationship between interest and time leads to the concept of the time value of money. In order to compare available alternatives, a basis for comparison that summarizes the significant differences between investment alternatives must be developed. The 
reduction of alternatives to a common base is necessary so that apparent differences become real differences, with the time value of money considered. The common bases for comparison are the present worth amount and the annual equivalent amount.

The preliminary step in a life cycle cost analysis is to estimate the investment costs. Investment costs or first costs consist of purchase, installation and interim financing costs associated with construction. Typical investment costs are the cost of land, cost of right of way, research and development costs, construction costs and the cost of equipment. A reasonable estimate of the investment costs can generally be derived from cost records of installations of similar design. However, accurate and reliable cost estimates can be expected only from quotations from manufacturers and vendors.

The projected useful life of the system is a necessary input to a life cycle cost analysis. The cost of money is a diract reflection of the method of financing. Care must be taken to study current money market trends before selectiny a representative interest rate. Funds for investor owned ventures are derived from both the risk capital (equity) and debt sapital (bond) markets. Facilities owned by the government are generally financed by long term bonds with interest rates faling between 7 and 8 percent. In addition, government owned ventures are self 
insured and are not concerned with taxes.

Operation and maintenance costs have to be projected over the useful life of the system and must be realistic assessments of expected costs.

In performing a life cycle cost analysis, it is important to recognize that some system components will require replacement during the useful life of the system. In order to conauct a realistic economic analysis, the analyst must realize that the capital cost of a piece of equipment (to be replaced at a future date) and the cost of borrowed capital for Euture equipment replacement will be higher than at present. The projected year end interest rates could be determined by using a polynomial function in time.

$$
\text { Year end interest rate }=a_{0}+a_{1} t+a_{2} t^{2}+a_{3} t^{3}
$$

where

$$
t \text { - time, years }
$$

The coefficients $a_{0}, a_{1}, a_{2}$ and $a_{3}$ can be conveniently determined by a least squares fit of past trends. This polynomial representation allows the interest rates to change non-uniformly with time.

$$
\text { Escalation Eactors for estimating future labor and }
$$
material costs could also be determined by using a polynomial function in time.

$$
i_{r}=b_{0}+b_{1} t+b_{2} t^{2}+b_{3} t^{3}
$$


where

$$
i_{r} \text { - escalation Eactor at year } r
$$

The estimated labor or material cost at year $r$ is then determined from the Eollowing relationship.

$$
F C_{r}=F C_{0}\left(1+i_{1}\right)\left(1+i_{2}\right) \ldots\left(1+i_{r}\right)
$$

where

$$
\begin{aligned}
& E C_{r} \text { - labor or material cost during year } r \\
& F C_{0} \text { - present cost of labor or materials }
\end{aligned}
$$

\section{Results}

The installed cost of a 10 megawatt TGIIC power plant was found to be $\$ 3,030$ per kilowatt. This relatively high capital cost is mainly due to the high cost of the heat exchangers which represent approximately tro-thiccs of the total investment.

The bushar cost of electricity using the customary method, was determined for the different sources of Eunding, and range from approximately 30 to $46 \mathrm{Mills} / \mathrm{kWh}$. These costs are presented in Table 4 . The cost of power of various power generation technologies is summarized in Table $5[6,9,10]$.

In computing the life cycle costs oi electricity, it was estimated that the useful life of amnonia and polyurethane insulation was ten years, resulting in four replacements over the projected life of the system. All 
Table 4 Busbar cost of electricity for a baseline 10 Mi TGUC power plant

Busbar rates, Mills/kWh

\begin{tabular}{|c|c|c|c|c|}
\hline Source of funds * & (A) & (B) & (C) & (D) \\
\hline Interest rate $\%$ & 7.0 & 7.5 & 8.7 & 9.5 \\
\hline $\begin{array}{l}\text { Deferred } \\
\text { construction cost }\end{array}$ & 2.62 & 2.62 & 2.62 & 2.62 \\
\hline Cost of money & 27.35 & 29.30 & 33.99 & 37.11 \\
\hline Insurance & 0.0 & 3.13 & 3.13 & 3.13 \\
\hline Depreciation & 0.0 & 0.82 & 0.55 & 0.39 \\
\hline Taxes & 0.0 & 2.34 & 2.34 & 2.34 \\
\hline Total & 29.37 & 38.21 & 42.63 & 45.59 \\
\hline
\end{tabular}

* See Table 2 (p. 33) for description of sources of funds. 
Table 5 Cost of power of various power generation technologies

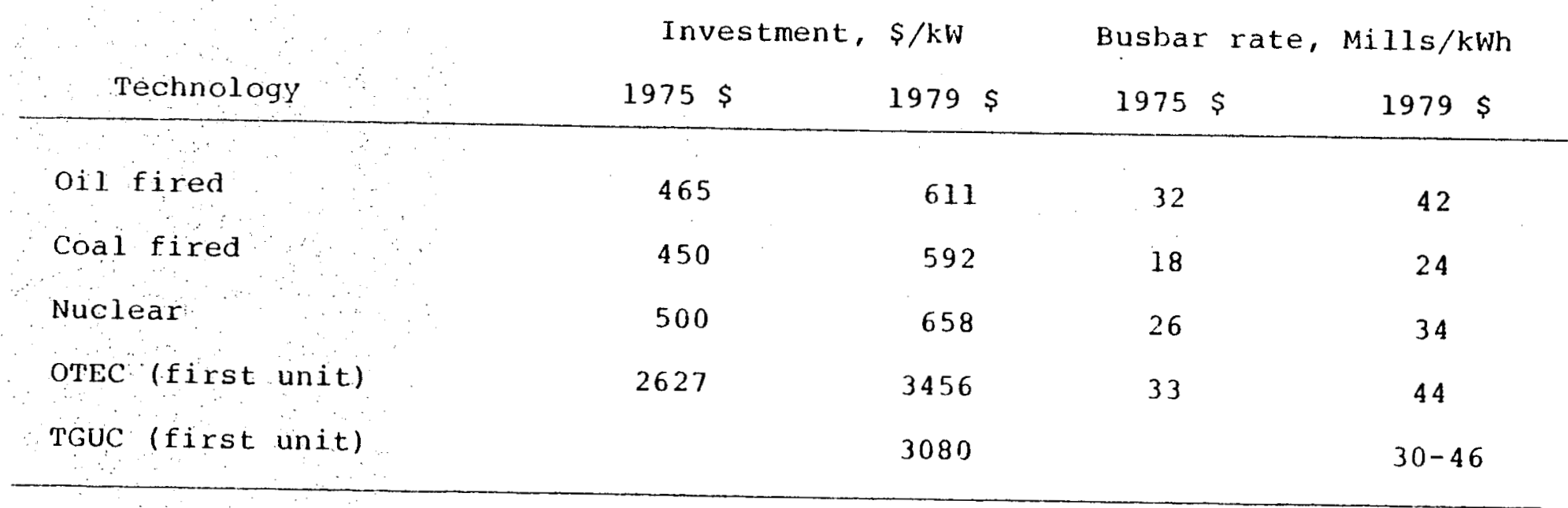


other components were assumed to have service lives of fifty years.

The projected year end interest rates and escalation factors for labor and materials were determined from past trends and are shown in Figs. 12 and 13. Both the interest rates and labor and material escalation rates variation with time were found to be linear, i.e. the coefficients $a_{2}, a_{3}, b_{2}$ and $b_{3}$ in equations (13) and (14) were zero. For publicly financed systems a first year bonus 20 percent depreciation and investment tax credits as permitted by the Internal Revenue Service [11] were considered.

The life cycle busbar costs of electricity of a baseIine 10 megawatt TGUC power plant, based on an availability factor of 0.9 , are summarized in Table 6 and range from 47 to $55 \mathrm{Mills} / \mathrm{kWh}$ depending on the type of financing. 


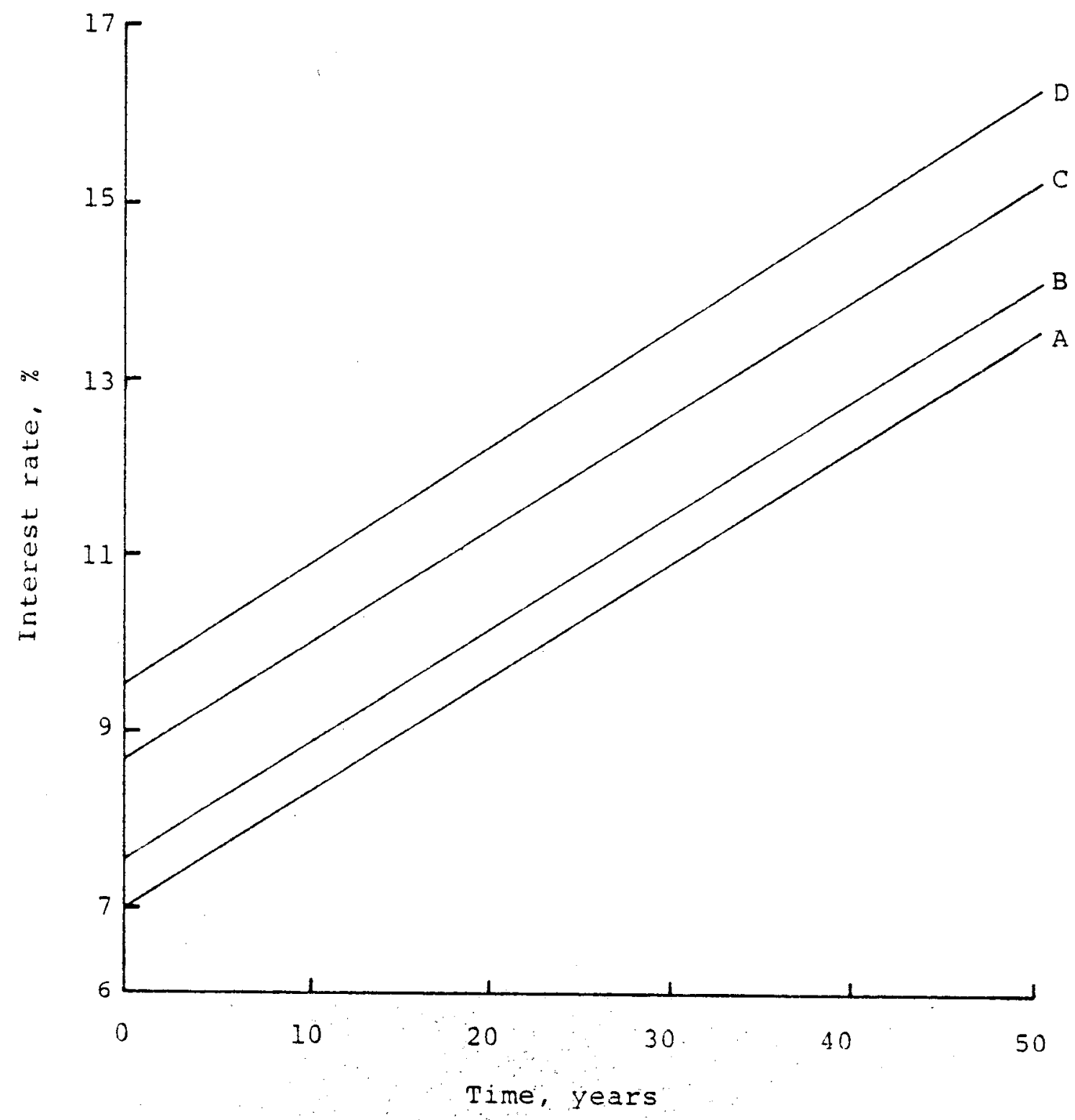

Fig. 12 Year end interest rates 


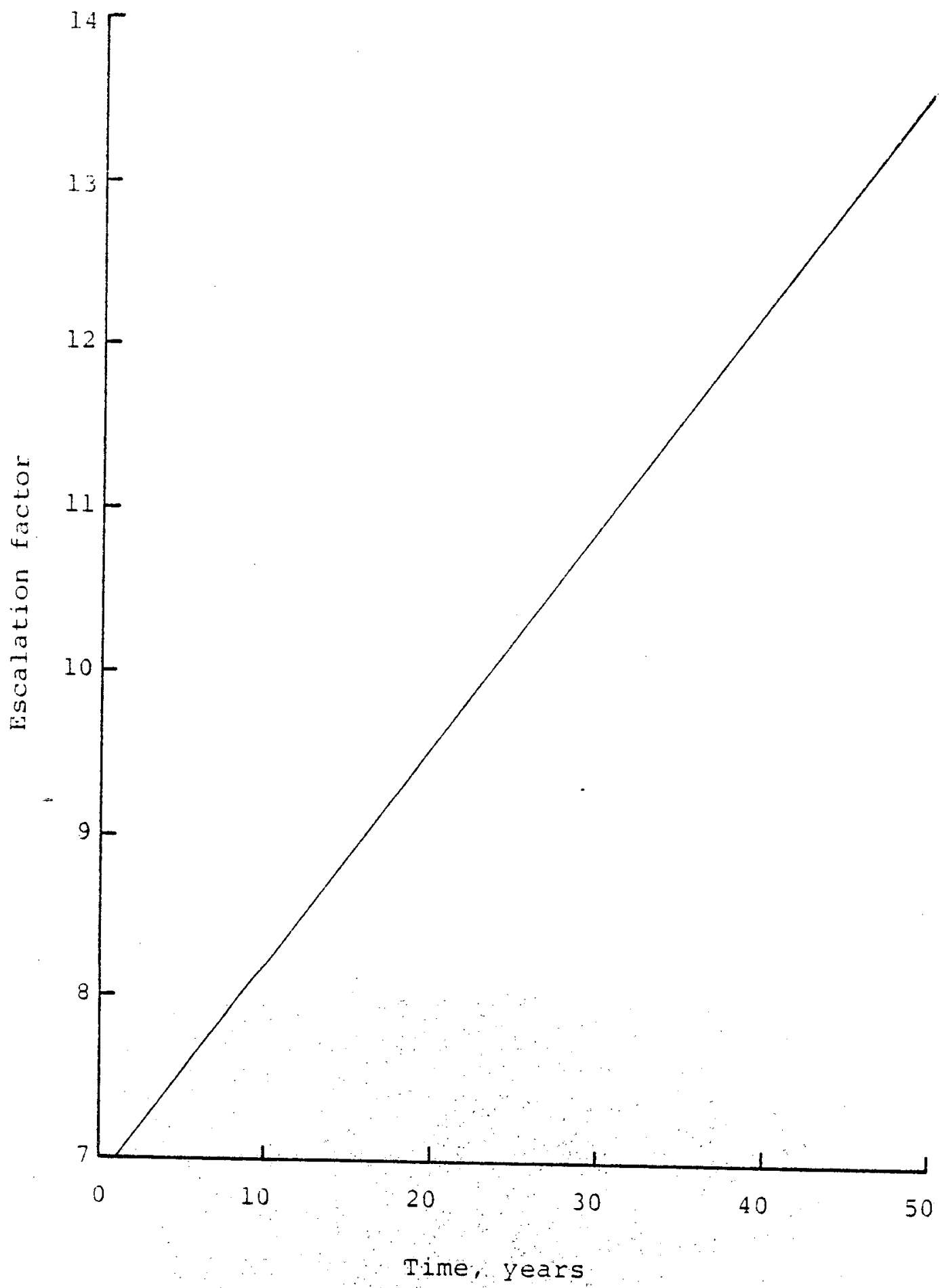

Fig. 13 Labor and materials escalation factors 
lable 6 life cycle busbar costs of electricity of a baseline lo MW TGuC power plant

\begin{tabular}{cccc} 
Source of funds* & Interest rate, $\%$ & $\begin{array}{c}\text { Installed } \\
\text { cost, } \$ / \mathrm{kW}\end{array}$ & Mills $/ \mathrm{kWh}$ \\
\hline A & 7.0 & 3080 & 47 \\
B & 7.5 & 3080 & 48 \\
C & 8.7 & 3080 & 51 \\
D & 9.5 & 3080 & 55 \\
\hline
\end{tabular}

* See rable 2 (p. 33) for description of sources of funds. 


\section{ENERGY ANALYSES}

Traditionally, technical and economic analyses have been used as decision making criteria, with no consideration given to a proposed project's demand on energy resources. The recent concern over the energy costs of various goods and services has prompted the development of methods to evaluate these costs.

In 1975, H. T. Odum [12] recognized the need for, and pioneered early work in the area of net energy analysis. In order to assess the efficiency of eneray usaqe, Ross et al. [13] developed a performance indicator known as the second law efficiency.

The following sections detail net energy analysis and second law analysis as applied to a TGUC power plant.

\section{Net Energy Analysis}

Net energy analysis is an accounting scheme that considers total energy inputs and outputs to arrive at indices of system performance known as energy ratios. The energy inputs are estimates of the energy expended to build and operate a system, with consideration given to the form of energy used. The energy output is that delivered by the system.

Net energy is defined as the energy remaining for use outside an energy system after deducting all the energy 
required for constructing and operating the system, as well as the energy content of the fuel. Energy costs are not limited to those incurred by or for the energy system being analyzed; they also include energy expenditures incurred elsewhere as a necessary result of constructing and operating the system under analysis.

Total energy expenditures are comprised of direct and indirect energy expenditures. Direct energy consists of all fuels and electricity used in all stages of construction and operation. Renewable forms of energy such as solar and wind energy are not considered as energy costs. Indirect energy expenditures include the energy embodied in system components, in materials used during construction and operation, and the energy associated with producing the fuels and electricity that are directly consumed.

An understanding of net energy analysis enables the analyst to identify system components that might be energy intensive. This provides a starting point for possible redesign of system components in order to decrease the overall energy cost of a system. In evaluating the feasibility of any energy conversion system, net energy analysis should be considered along with technical and economic analyses. A net energy study, however, is not intended to replace an economic analysis as a criterion to deploy a potential project, but to strengthen a decision based on an economic analysis, if a positive net energy is obtained. 
Method of Analysis

A net energy analysis involves the quatitative determination of all relevant energy flows, and the aggregation of these energy flows into meaninaful indices of system performance.

Energy intensity coefficients $\left(10^{6}\right.$ BTU per ton) developed by Perry et al. [14] were used to estimate the energy embodied in the system. Perry et al. provide six energy intensity coefficients for each of 52 input-output (I/O) sectors of the U.S. economy. These energy coefficients were in turn developed from energy data reported by Bullard et al. [15], and input-output analysis [14]. I/O analysis uses a set of energy intensity coefficients $\left(10^{6}\right.$ BTU per dollar) for various sectors of the U.S. economy, and cost estimates (dollars per ton) for various I/O sectors to arrive at Perry's energy coefficients (BTU per ton).

Energy expenditures for the system can be calculated from the energy intensity coefficients and the weights of materials in the system components. The energy expenditures associated with constructing and operating the system are reported individually. The construction energy expenditures are comprised of direct and indirect energy embodied in the system components, as well as the energy used during construction. operational energy expenditures include those for operating the facility as well as for maintaining it. 
Initialiy, the energy costs are presented as total primary energy which is, by convention of the U.S. Bureau of Mines, the sum of coal, crude oil, and natural gas, and the fossil energy required to produce the electricity generated by nuclear and hydroelectric plants. The total primary energy is then separated into the energy used for the generation of electricity, and the energy used directly for heat. This is accomplished by realizing that,

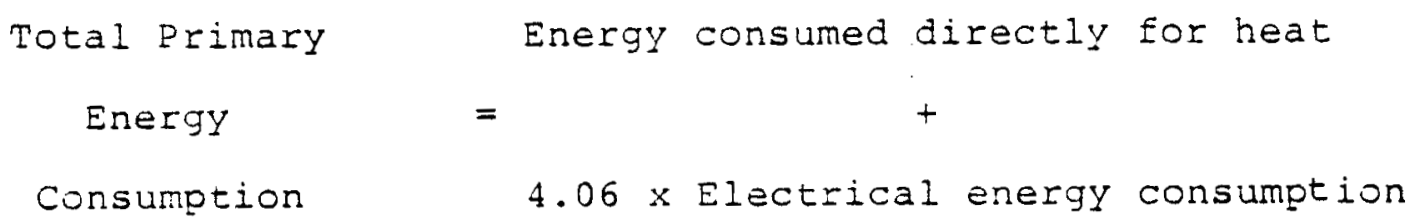

$4.06 \times$ Electrical energy consumption

The factor, 4.06 , represents the number of BTU's of total primary energy required to produce one BTU of electricity. Energy intensity coefficients for various $I / O$ sectors are shown in Table 7 [14].

As shown by Fig. It and Table 8 , net energy is the difference between the delivered energy product and the total primary energy.

$$
\mathrm{TP}=\mathrm{w}_{1} E_{S}+\sum_{i=2}^{n} w_{i} S_{i}
$$

where

$$
\begin{aligned}
& T P \text { - total primary energy } \\
& n \text { - total number of energy inputs of different forms } \\
& E_{S} \text { - total electrical subsidy }
\end{aligned}
$$


Table 7 Energy embodied in the average output of selected industries $\left(10^{6}\right.$ BTU per short ton of average product)

\begin{tabular}{|c|c|c|c|c|c|c|c|}
\hline $\begin{array}{c}1 / 0 \\
\text { sector } \\
\end{array}$ & $\begin{array}{c}\text { Industry } \\
\text { name }\end{array}$ & Coal & $\begin{array}{c}\text { Crude } \\
\text { Oil } \\
\end{array}$ & $\begin{array}{c}\text { Refined } \\
\text { Petroleum }\end{array}$ & Elec. & Gas & Primary \\
\hline 32.04 & Miscellaneous plastics & 42.0 & 96.0 & 36.0 & 12.9 & 58.0 & 146.0 \\
\hline $36: 10$ & Concrete blocks & 0.72 & 1.53 & 0.56 & 0.12 & 0.94 & 2.33 \\
\hline 36.11 & concrete products & 0.99 & 1.66 & 0.54 & 0.14 & 1.08 & 2.74 \\
\hline 36.12 & Ready-mix concrete & 0.51 & 0.88 & 0.34 & 0.07 & 0.53 & 1.44 \\
\hline 37.01 & Steel products & 30.0 & 20.0 & 5.0 & 2.5 & 14.0 & 51.0 \\
\hline 37.02 & Iron-steel foundry & 15.0 & 18.0 & 5.0 & 3.0 & 13.0 & 35.0 \\
\hline 37.03 & Iron-steel forgings & 40.0 & 43.0 & 14.0 & 4.6 & 28.0 & 86.0 \\
\hline 37.04 & Primary metal production & 38.0 & 42.0 & 17.0 & 17.1 & 72.0 & 138.0 \\
\hline 38.01 & Primary copper & 32.0 & 81.0 & 30.0 & 11.3 & 50.0 & 120.0 \\
\hline 38.02 & Primary lead & 14.0 & 28.0 & 8.0 & 3.4 & 19.0 & 44.0 \\
\hline 38.03 & Primary zino & 29.0 & 41.0 & 5.0 & 5.8 & 34.0 & 73.0 \\
\hline 38.04 & Primary aluminum & 81.0 & 100.0 & 19.0 & 40.0 & 77.0 & 206.0 \\
\hline 38.07 & Copper rollings & 37.0 & 86.0 & 33.0 & 13.8 & 52.0 & 131.0 \\
\hline 38.08 & Aluminum rollings & 81.0 & 116.0 & 24.0 & 39.1 & 88.0 & 222.0 \\
\hline 38.09 & Non-ferrous rollings & 74.0 & 134.0 & 32.0 & 26.7 & 98.0 & 224.0 \\
\hline 38.10 & Non-ferrous wire & 35.0 & 70.0 & 26.0 & 12.9 & 43.0 & 113.0 \\
\hline 38.11 & Aluminum castings & 71.0 & 124.0 & 25.0 & 31.1 & 95.0 & 214.0 \\
\hline 38.12 & Brass castings & 60.0 & 129.0 & 40.0 & 21.8 & 86.0 & 202.0 \\
\hline 38.13 & Non-ferrous castings & 64.0 & 103.0 & 22.0 & 20.8 & 78.0 & 180.0 \\
\hline 38.14 & Non-ferrous forgings & 166.0 & 252.0 & 60.0 & 51.2 & 184.0 & 448.0 \\
\hline 40.04 & Fabricated str. steel & 25.0 & 23.0 & 7.0 & 3.1 & 15.0 & 50.0 \\
\hline 40.05 & Metal doors & 81.0 & 116.0 & 29.0 & 29.2 & 83.0 & 214.0 \\
\hline 40.06 & Fabricated plate work & 53.0 & 53.0 & 17.0 & 7.2 & 35.0 & 111.0 \\
\hline 40.07 & Sheet metal work & 55.0 & 58.0 & 18.0 & 9.6 & 38.0 & 119.0 \\
\hline 42.08 & Pipe fittings & 36.0 & 57.0 & 25.0 & 7.0 & 31.0 & 97.0 \\
\hline 43.01 & Steam engines & 138.0 & 179.0 & 80.0 & 23.7 & 95.0 & 332.0 \\
\hline
\end{tabular}


Table 7 (continued)

\begin{tabular}{|c|c|c|c|c|c|c|c|}
\hline $\begin{array}{c}1 / 0 \\
\text { sector }\end{array}$ & $\begin{array}{c}\text { Industry } \\
\text { name }\end{array}$ & Coal & $\begin{array}{c}\text { Crude } \\
\text { Oil } \\
\end{array}$ & $\begin{array}{c}\text { Refined } \\
\text { Petroleum }\end{array}$ & Elec. & Gas & Primary \\
\hline 43.02 & I.C. Engine & 61.0 & 83.0 & 30.0 & 14.5 & 51.0 & 153.0 \\
\hline 44.00 & Farm machines & 38.0 & 44.0 & 15.0 & 6.1 & 28.0 & 86.0 \\
\hline 45.01 & Construction machinery & 42.0 & 47.0 & 16.0 & 7.2 & 30.0 & 94.0 \\
\hline 45.02 & Mining nachinery & 63.0 & 71.0 & 23.0 & 10.6 & 46.0 & 140.0 \\
\hline 45.03 & oil field machinery & 66.0 & 100.0 & 44.0 & 13.1 & 54.0 & 173.0 \\
\hline 46.01 & Elevators & 53.0 & 68.0 & 25.0 & 10.1 & 41.0 & 127.0 \\
\hline 46.02 & Conveyors & 49.0 & 54.0 & 18.0 & 7.7 & 34.0 & 107.0 \\
\hline 46.03 & Hoists and cranes & 51.0 & 58.0 & 19.0 & 8.9 & 37.0 & 114.0 \\
\hline 46.04 & Industrial trucks & 40.0 & 48.0 & 17.0 & 6.6 & 30.0 & 92.0 \\
\hline 49.01 & Pumps and compressors & 44.0 & 60.0 & 22.0 & 9.1 & 37.0 & 110.0 \\
\hline 49.02 & Bearings & 92.0 & 99.0 & 34.0 & 15.5 & 63.0 & 202.0 \\
\hline 49.05 & Power transmission eq. & 60.0 & 79.0 & 26.0 & 12.0 & 50.0 & 146.0 \\
\hline 49.06 & Industrial furnaces & 115.0 & 143.0 & 50.0 & 18.6 & 88.0 & 269.0 \\
\hline 51.01 & Computing machinery & 349.0 & 614.0 & 273.0 & 96.4 & 325.0 & 1022.0 \\
\hline 53.02 & Transformers & 37.0 & 43.0 & 16.0 & 7.5 & 26.0 & 85.0 \\
\hline 53.03 & Switchgear & 93.0 & 144.0 & 55.0 & 24.6 & 85.0 & 252.0 \\
\hline 53.04 & Motors and generators & 54.0 & 70.0 & 25.0 & 11.7 & 43.0 & 131.0 \\
\hline 53.06 & Welding apparatus & 62.0 & 81.0 & 22.0 & 10.9 & 56.0 & 150.0 \\
\hline 53.07 & Carbon products & 72.0 & 112.0 & 23.0 & 31.0 & 85.0 & 203.0 \\
\hline
\end{tabular}


Energy inputs

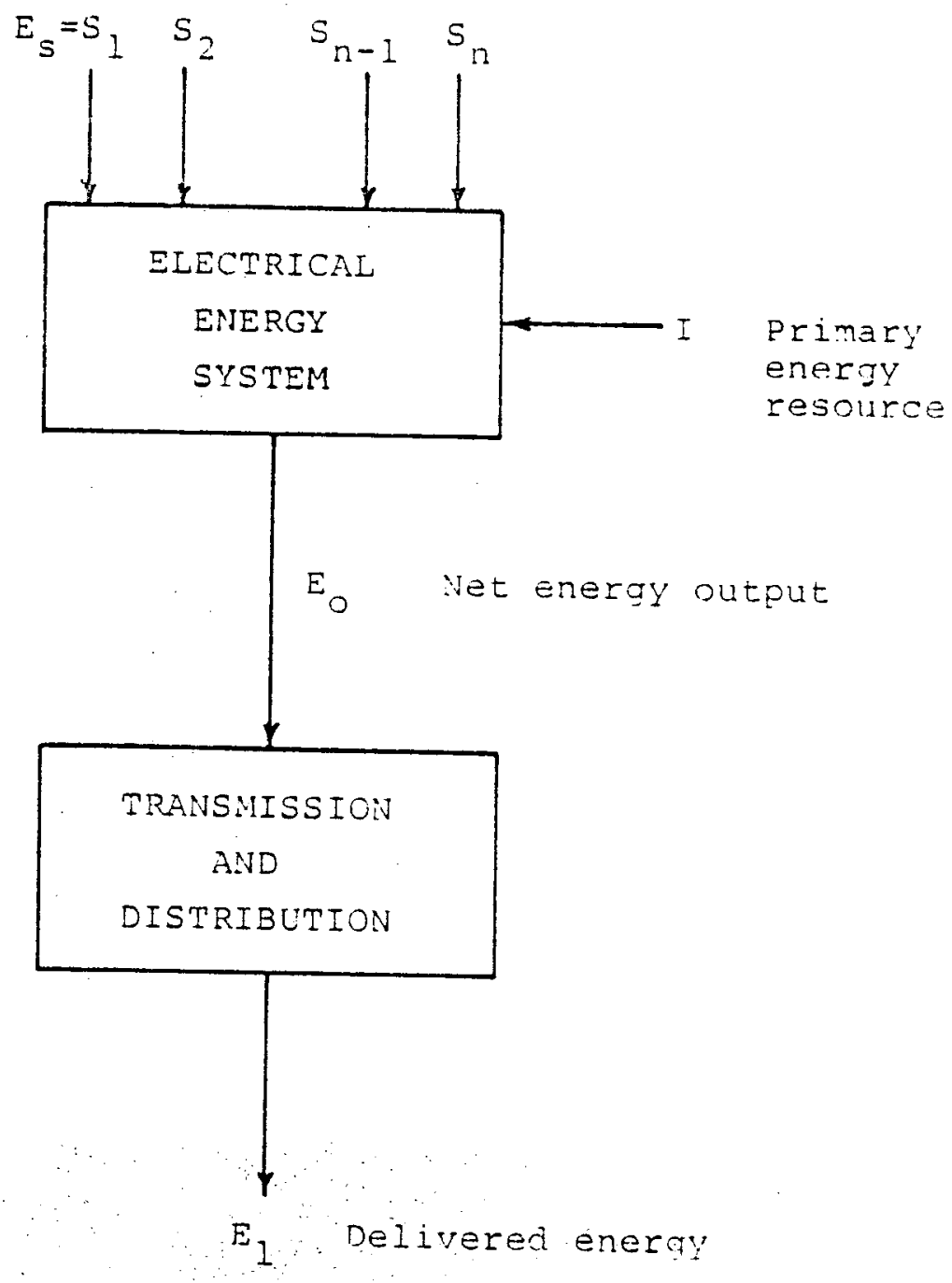

Fig. 14 Electrical energy system with $n$ different energy Eorms 
Table 8 Nomenclature for energy inputs and outputs

\section{Average Annual Energy Outputs:}

$E_{0}$ - net output of energy production system, BTU/year

$E_{1}$ - delivered output, BTU/year (kwh/year)

Average Annual Energy Inputs:

I - primary energy resource (fuel) processed, BTU/year

= conventional heat rate (BTU/kWh) $\mathrm{x}$ net output (kWh/year) for electrical systems

$E_{s}$ - electrical energy subsidy, BTU/year (kWh/year)

$\mathrm{T}_{1}$ - primary energy subsidy for generation and delivery of electricity, BTU/year

$=4.06 \times E_{S}$

$\mathrm{T}_{2}$ - thermal energy subsidy, BTU/year

TP - total primary energy subsidy, BTU/year

$=T_{1}+T_{2}$ 


$$
\begin{gathered}
s_{i}-\text { total energy subsiay of energy type } i \\
w_{i} \text { - weighting factor for energy type } i \\
E_{\text {net }}=E_{1}-\mathrm{TP}
\end{gathered}
$$

where

$$
\begin{aligned}
& E_{\text {net }} \text { - net energy } \\
& E_{1} \text { - delivered output }
\end{aligned}
$$

The weighting factors $w_{1}, w_{2}, \ldots, w_{n}$ are fixed by convention of the U.S. Bureau of Mines to be 1.0 for coal, oil and natural gas, and 4.06 for electricity. Definitions and symbols for energy outputs and expenditares are shown in Table 8 (p. 53).

The net output of the system, $E_{O^{\prime}}$ is the amount of energy actually delivered by the system after the deduction of energy used within the facility. The delivered output, $E_{1}$, is the amount of energy delivered to the consumer, after accounting for transmission losses.

Indices of System Performance

The results of a net energy analysis are reported in terms of indices of system performance or energy ratios. A description of these ratios is presented in Table 9. The energy ratio, $R_{0}$, is defined as the amount of energy delivered by the energy conversion system for each unit of fossil fuel energy expended, assuming that all electrical 
Table 9 Indices of system performance

Energy ratios:

$R_{0}=\frac{\text { Delivered energy product }}{\text { Total primary energy subsidy }}=\frac{E_{1}}{T P}$

$R_{I}$ - Total primary energy subsidy expressed as BTU input per 1000 BTU output $=\frac{1000}{R_{0}}$

$R_{3}=$ Delivered electricity - electrical subsidy

Thermal energy subsidy

$=\frac{E_{1}-E_{S}}{T_{2}}$

$R_{4}$ - Thermal energy subsidy expressed as BTU input per 1000 BTU output $=\frac{1000}{R_{3}}$

Heat rates:

$H_{1}$ - Subsidy heat rate $=\frac{T P}{E_{I}}$

$\mathrm{H}_{4}$ - Subsidy heat rate for net system output

$=\frac{T_{2}}{E_{1}-E_{S}}$

$G_{1}$ - Overall heat rate $=\frac{I+T P}{E_{1}}$ 
energy requirements are met by fossil fuel power sources. The energy ratio, $R_{4}$, represents the net electrical energy delivered by the system for every unit of thermal energy input. The heat rate, $G_{1}$, represents the energy cost of electricity per kilowatt-hour of delivered output.

Results of the Net Energy Analysis

The energy budget shown in Table 10 was derived from weights of materials in system components and the energy intensity coefficients shown in Table 7 (p. 50). The material weights were estimated from manufacturers' speciEications and represent a ten percent markup to account for material wastage during fabrication.

The energy cost of construction (estimated to be 20 percent of energy embodied in steell is the same percentage used by perry et al. [1t] in their net energy analysis of an Ocean Thermal Energy Conversion power plant.

The annualized energy expencitures were determined by dividing the estimated total energy cost of a system component by its anticipated useful life. The energy expenditures are further broken down as follows:

(a) Electrical energy inputs

(b) Primary energy associated with producing and delivering the electrical energy inputs

(c) Primary energy used directly for heat

(d) Total primary energy 
Table 10 Energy expenditures for a $10 \mathrm{MW}$ TGUC power plant

\begin{tabular}{|c|c|c|c|c|c|c|c|c|}
\hline \multirow[b]{2}{*}{ component } & \multirow{2}{*}{$\begin{array}{c}\text { Mass } \\
10^{3} \text { short } \\
\text { tons }\end{array}$} & \multirow{2}{*}{$\begin{array}{l}\text { Energy } \\
\text { Intensity } \\
10^{6} \mathrm{BTU} / \mathrm{ton}\end{array}$} & \multirow{2}{*}{$\begin{array}{l}\text { Life } \\
\text { yr }\end{array}$} & \multirow{2}{*}{$\begin{array}{l}\text { Total } \\
\text { energy } \\
100 \mathrm{BTU}\end{array}$} & \multicolumn{4}{|c|}{ Annualized Inputs } \\
\hline & & & & & $\frac{\text { Eles }}{10^{6} \mathrm{kWh} / \mathrm{yr}}$ & $\frac{c t r i c a l}{10^{10} \mathrm{BTU} / \mathrm{Yr}}$ & $\begin{array}{l}\text { Thermal } \\
1010 \mathrm{BTU} / \mathrm{yr}\end{array}$ & $\begin{array}{c}\text { Total } \\
10^{10} \mathrm{BTU} / \mathrm{yr}\end{array}$ \\
\hline $\begin{array}{l}\text { PIPES } \\
\text { Steel } \\
\text { Pabrication } \\
\text { Subtotal }\end{array}$ & $5: 25$ & 111 & 50 & $\begin{array}{l}58.275 \\
11.655 \\
69.930\end{array}$ & $\begin{array}{l}0.222 \\
0.044 \\
0.266\end{array}$ & $\begin{array}{l}0.307 \\
0.061 \\
0.368\end{array}$ & $\begin{array}{l}0.859 \\
0.172 \\
1.031\end{array}$ & $\begin{array}{l}1.166 \\
0.233 \\
1.399\end{array}$ \\
\hline $\begin{array}{l}\text { TURBINES } \\
\text { Steel } \\
\text { Copper } \\
\text { Construction } \\
\text { Subtotal }\end{array}$ & $\begin{array}{l}0.030 \\
0.025\end{array}$ & $\begin{array}{l}111 \\
131\end{array}$ & $\begin{array}{l}50 \\
50\end{array}$ & $\begin{array}{l}0.333 \\
0.328 \\
0.067 \\
0.728\end{array}$ & $\begin{array}{l}0.0012 \\
0.0020 \\
0.0002 \\
0.0034\end{array}$ & $\begin{array}{l}0.001 .7 \\
0.0028 \\
0.0003 \\
0.0048\end{array}$ & $\begin{array}{l}0.0050 \\
0.0038 \\
0.0010 \\
0.0098\end{array}$ & $\begin{array}{l}0.0067 \\
0.0066 \\
\frac{0.0013}{0.0146}\end{array}$ \\
\hline $\begin{array}{l}\text { HEAT EXCHANGEI } \\
\text { Steel } \\
\text { Aluminum } \\
\text { Fabrication } \\
\text { Construction } \\
\text { Subtotal }\end{array}$ & $\begin{array}{r}4.95 \\
0.55\end{array}$ & $\begin{array}{l}111 \\
222\end{array}$ & $\begin{array}{l}50 \\
50\end{array}$ & $\begin{array}{r}54.945 \\
12.210 \\
24.750 \\
10.989 \\
102.894\end{array}$ & $\begin{array}{l}0.209 \\
0.126 \\
0.090 \\
0.042 \\
0.467\end{array}$ & $\begin{array}{l}0.289 \\
0.175 \\
0.125 \\
0.058 \\
0.647\end{array}$ & $\begin{array}{l}0.810 \\
0.069 \\
0.370 \\
0.162 \\
1.411\end{array}$ & $\begin{array}{l}1.099 \\
0.244 \\
0.495 \\
0.220 \\
2.058\end{array}$ \\
\hline AMMON I A & 0.50 & 39 & 10 & 1.950 & 0.0 & 0.0 & 0.195 & 0.195 \\
\hline INSULATION & 0.092 & 146 & 10 & 1.343 & 0.035 & 0.048 & 0.086 & 0.134 \\
\hline 'IOTAL & & & & & 0.807 & 1.1178 & 2.9328 & 4.0506 \\
\hline
\end{tabular}


The total energies required to construct one 10 MW TGUC power plant are as follows:
Electrical energy input
$3.72 \times 10^{7} \mathrm{kWh}$
Primary energy required to
produce electrical energy input
$5.15 \times 10^{11} \mathrm{BTU}$
Primary energy required to
produce heat
$1.25 \times 10^{12}$ BTU
Total primary energy
$1.77 \times 10^{12} \mathrm{BTU}$

The uncertainties in the determination of the energy inputs are estimated to be \pm 30 percent. Factors contributing to the uncertainties in estimation are outlined below.

(a) The statistical data base on which Bullard's energy intensity coefficients are based is subject to uncertainty.

(b) The statistical data base represents 1967 U.S. industrial practices. Thus, no allowance is made for technological improvements since 1967.

(c) The net energy analysis overlooks potential improvements in energy utilization efficiencies.

(d) The energy intensity coefficients for the various I/O sectors are averages. Thus, typical members of the I/O sector are often misrepresented by the energy intensity coeficicients.

In calculating the indices of system performance, a 
capacity factor of 0.9 was used, and transmission and distribution losses were estimated to be ten percent of the net system output. In addition, the thermal energy in the atmosphere needed to vaporize the working fluid in the power cycle was regarded as "free energy." The indices of system performance for a 10 MW TGUC power plant are presented in Table 11. Table 12 summarizes the energy cost of electricity of a TGUC power plant and other power generation technologies [16].

The results of this net energy analysis indicate that the net energy. of a TGUC system is favorable, and that a decision to proceed with the deployment of a TGUC power plant should be based on other considerations.

\section{Second Law Analysis}

In addition to net energy analysis, the effectiveness or second law efficiency of an energy conversion process can be usea as a decision making tool. Often, the first law efficiency is used as an energy performance indicator although its use can be misleading.

The first law of thermodynamics states that the disappearance of one energy form results in the appearance of an equal amount of energy in another form, 1 .e. there is no recognition of the quality of energy. For all energy conversion systems, the first law is simply a book-keeping device that ensures that energy is nejther created nor des- 
Table 11 TGUC inputs, outputs and indices of system performance

$$
\begin{aligned}
& E_{0}=10000 \mathrm{~kW} \times 8760 \mathrm{hrs} / \mathrm{yr} \times 0.9=7.884 \times 10^{7} \mathrm{kWh} / \text { year } \\
& E_{1}=7.884 \times 10^{7} \mathrm{kwh} / \mathrm{yr} \times 0.9=7.0956 \times 10^{7} \mathrm{kWh} / \text { year } \\
& =2.4217 \times 10^{11} \mathrm{BTU} / \text { year } \\
& E_{s}=0.807 \times 10^{6} \mathrm{krh} / \text { year } \\
& =2.750 \times 10^{9} \mathrm{BTU} / \text { year } \\
& \mathrm{T}_{1}=1.118 \times 10^{10} \mathrm{BTU} / \text { year } \\
& \mathrm{T}_{2}=2.933 \times 10^{10} \mathrm{BTU} / \text { year } \\
& T P=4.051 \times 10^{10} \mathrm{BTU} / \text { year } \\
& I=0 \\
& R_{0}=\frac{2.4217 \times 10^{11}}{10}=\underline{5.979} \\
& 4.051 \times 10^{10} \\
& R_{1}=\frac{1000}{5.979}=167.3 \text { BTU input per } 1000 \text { BTU output } \\
& R_{3}=\frac{(2.4217-0.0275) \times 10^{11}}{2.933 \times 10^{10}}=\frac{3.164}{2} \\
& R_{4}=\frac{1000}{8.164}=122.5 \text { ETU input per } 1000 \text { BTU output } \\
& \mathrm{H}_{1}=\mathrm{G}_{1}=\frac{4.051 \times 10^{10}}{7.0956 \times 10^{7}}=\frac{570.9 \mathrm{BTU} / \mathrm{KWh}}{} \\
& \mathrm{H}_{4}=\frac{2.933 \times 10^{10}}{(7.0956-0.0807) \times 10^{7}}=418.1 \mathrm{BWU} / \mathrm{kWh}
\end{aligned}
$$


Table 12 Energy cost of electricity of various power generation technologies

\begin{tabular}{lc} 
Technology & $\begin{array}{c}\text { Energy cost } \\
\text { BTU/kWh }\end{array}$ \\
\hline TGUC & 571 \\
OTEC & 340 \\
Gas fired & 9000 \\
Coal fired & 8800 \\
Oil fired & 8900 \\
Nuclear & 10500 \\
\hline
\end{tabular}


troyed, but merely changed in form.

All energy conversion processes convert energy from more useful forms to less useful forms, i.e. energy is degraded. For example, fossil fuels (high quality energy) can be converted into electricity, work and high temperature heat (high quality energy) as well as low temperature heat (low quality energy). The first law of thermodynamics does not reflect degradation of energy since it is only concerned with the conservation of energy. However, the second law efficiency is a measure of the performance of the system and does reflect tine degradation of energy.

The thermodynamic effectiveness of an energy conversion system is defined as the ratio of the useful work output to the maximum output that could be obtained from the same energy conversion system. The effectiveness is an indicator of how well a specific system executes a task, relative to how efficiently that task could have been performed by an ideal system. The effectiveness is also a measure of how much improvement in the performance of a system is possible. Maximizing the effectiveness will minimize the energy consumption for a given process.

The carnot efficiency is the ratio of the maximum available work to the energy inout, and the thermal efficiency is defined as the ratio of actual work output to the energy input. Thus, 


$$
\varepsilon=\frac{n_{t h}}{n_{c}}
$$

where

E - effectiveness or second law efficiency

$n_{\text {th }}$ - thermal efficiency

$n_{C}$ - Carnot efficiency

For the Palm Springs TGUC system operating with a temperature difference of $45^{\circ} \mathrm{F}$ and with a heat source temperature of $110^{\circ} \mathrm{F}$, the carnot efficiency is

$$
{ }^{n_{C}}=\frac{45^{\circ} \mathrm{R}}{(110+460)^{O_{R}}}=0.0789
$$

The thermal efficiency of the Palm springs TGUC system is 0.018 . Thus,

$$
\varepsilon=\frac{0.018}{0.0789}=0.23
$$

The second law efficiencies of various electric power plants are shown in Table $13[16,17]$. 
Table 13 Second law ếficiencies of single baseload electric power plants

\begin{tabular}{lc}
$\begin{array}{c}\text { Plant } \\
\text { description }\end{array}$ & $\begin{array}{c}\text { Second law } \\
\text { efficiency }\end{array}$ \\
\hline Hydroelectric & 0.80 \\
Coal fired & 0.33 \\
Oil fired & 0.33 \\
Gas fired & 0.33 \\
Nuclear & 0.56 \\
OTEC & 0.34 \\
TGUC & 0.23 \\
\hline
\end{tabular}




\section{CONCLUSIONS}

The computer modelling of the Thermal Gradient Utilization cycle established the technical feasibility of the power cycle. Condensation of the working fluid in the vapor pipe will not be an operational problem with the proper selection of a working fluid.

An optimum design configuration of a TGUC system depends on the conditions characteristic of a particular site, i.e. elevation, atmospheric conditions, and the energy source available. For a particular temperature gradient and desired power output, optimum pipe sizes and insulation thicknesses can be determined.

The selection of a working fluid is dependent on the temperature of the energy source. High density working fluids can be used with high temperature heat sources, resulting in smaller pipe sizes for a given power output or a greater power output for a given configuration.

Large elevations require cascading of power turbines due to pressure limitations:

Power output is a linear function of mass flow rate and elevation. The mass flow rate can be changed by changing the size of the vapor pipe.

A TGUC can be used to produce power in mountainous regions where atmospheric temperatures are high and an energy source is available such a system could also be used to supply heating at higher altitudes or cooling at 
at lower altitudes with power generated as a by-product.

The initial investment costs of a TGUC power plant are relatively high compared to conventional power generation technologies, but the busbar cost of electricity, over the useful life of 50 years, is competitive. The TGUC is economically competitive with OTEC systems in terms of investment costs $(\$ / \mathrm{kW})$ and the busbar costs (Mills/kWh).

The high capital cost of a TGUC power plant is largely due to the high cost of the heat exchangers which represent approximately two-thisus of the total investment. Thus, future efforts in cost reduction should be concentrated on design modifications of the heat exchangers.

Inherent in the TGUC concept of power production is the long service life of system components, and its independence of rising fuel costs that affect conventional technologies. Thus, TGUC power plants could be economically viable options in the future, in view of the inevitable escalation in fossil fuel costs.

The Thermal Gradient Utilization Cycle has a favorable net energy and decisions to proceed with the deployment of a TGUC power plant should be based on other considerations. The second law efficiency or effectiveness of a TGUC power plant was found to be 23 percent, the thermal efficiency being 1.8 percent: 


\section{REFERENCES}

1 Parker, S. A., "Power Generation Using Thermal Vapor Pumping and Hydro-pumped Storage," Proceedings of the Fifth Energy Technology Conference, Washington D.C., 1978, pp. $786-795$.

2 Fox, R. W., and McDonald, A. T., Introduction to Eluid Mechanics, Wiley, New York, 1978, pp. 544-549.

3 Urieli, I., A Computer Simulation of Sterling Cycle Machines, Ph.D. thesis, University of Witwatersrand, Johannesburg, South Africa, 1977, pp. 163-184.

4 Gerald, C. F., Applied Numerical Analysis, Addison-Wesley, Reading, Massachussetts, 1978, pp. 257-260.

5 Thermodynamic Properties of Refrigerants, American Society of Heating, Refrigerating and Air-Conditioning Engineers, New York, 1969.

6 Marks! Standard Handbook for Mechanical Engineers, T. Baumeister, ed., McGraw-Hi11, New York, 1978, Pp. 17.3317.43.

7 Anderson, S. A., and Iseri, T. M., Energy Economics and Life Cycle cost Analysis program for Building HVAC Systems, Anderson Engineering, College Station, 1979, P. B-6.

8 Theusen, H. G., Eabrycky, W. J., and Theusen, G. J., 
Engineering Economy, Prentice-Hall, Englewood Cliffs, New Jersey, 1977, pp. 337-339.

9 Ocean Thermal Energy Conversion (OTEC) Power Plant Technical and Economic Feasibility, Lockheed Missles and Space Company, Inc., NSE/RANN/SE/GI-C937/FR/75, April 1975.

10 Aschner, F. S., Planning Eundamentals of Thermal Power Plants, Wiley, New York, 1978, pp. 648-670.

I1 Bussey, L. E., The Economic Analysis of Industrial Projects, Prentice-Hall, Englewood Cliffs, New Jersey, 1978, pp. $72-151$.

12 NSE - Stanjord Workshop on Wet Energy Analysis, Institute for Energy Studies, Stanford University, 1975.

13 Ross, M., and Socolow, R. H., "Efficient Use of Energy," AIP Conference Proceedings NO. 25, New York, 1975.

14 Perry, A. M., Devine, W. D., Cameron, A. E., Marland, G., Reister, D. B., Treat, N. L., and Whittle, C., Net Energy Analysis of Eive Energy Systems," Oak Ridge Associated Universities, Inc., ORAU/IEA(R)-77-12, 1977 , pp. 1-118.

I5 Bullard, C. W., Penner, P. S., and Pilati, D. A., Energy Analysis Handbook, Center for Advanced Comoutation, Doc. 214, Urbana-Champaign, 1976, pp. 31-64. 
16 Loftress, R. L., Energy Handbook, Van Nostrand Reinhold, New York, 1978, pp. 583-604.

17 Carlson, T. C. G., and Goss, W. P., Mechanical Engineering, Vol. 102, No. 1, 1980, p. 38 .

18 Welty, J. R., Wicks, C. E., and Wilson, R. E., Fundamentals of Momentum, Heat and Mass Transfer, Wiley, New York, 1969, p. 351 . 


\section{APPENDIX A: GOVERNING EQUATIONS}

The development of the momentum and energy equations for the vapor and liquid pipes of the TGUC system are presented in this section.

\section{Momentum Equation}

The momentum equation is based on Newton's second law of motion which states that the rate of change of linear momentum of a body is proportional to the net applied force. For a control volume,

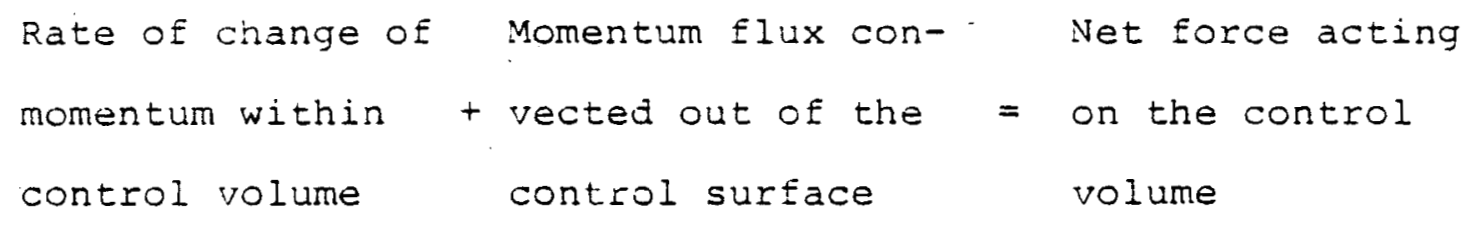

Thus,

$$
\frac{\partial}{\partial t} \int_{V}^{\bar{v} \rho d V}+\int_{A}^{\bar{v} \rho \bar{V} \cdot d \bar{A}}=-\int_{A}^{D} \cdot d \bar{A}-\bar{F}
$$

where

$$
\begin{aligned}
& \rho \text { - density of the fluid, } \mathrm{kg} / \mathrm{m}^{3} \\
& \bar{v} \text { - velocity of the fluid, } \mathrm{m} / \mathrm{s} \\
& d v \text { - differential volume, } \mathrm{m}^{3} \\
& p \text { - pressure, Pa }
\end{aligned}
$$

The applied force, $\bar{F}$ consists of the frictional drag force, $\overrightarrow{\bar{E}}_{S}$ and the body force, $\overline{\mathrm{F}}_{B}$. 
On applying Gauss' theorem to equation $(A-1)$,

$$
\frac{\partial}{\partial t} \int_{V}^{\bar{v}_{\rho} d V}+\int_{V}^{\nabla\left(\rho \bar{V}^{2}\right) d V}=-\int_{V} \nabla p d V-\bar{F}_{S}-\bar{F}_{B}
$$

Upon integrating, equation $(A-2)$ reduces to,

$$
\frac{\partial}{\partial t}(\rho \bar{V} V)+V \nabla\left(\rho \bar{V}^{2}\right)=-V \nabla p-\bar{F}_{S}-\bar{F}_{B}
$$

Simplifying equation $(A-3)$ for a one-dimensional case,

$$
\frac{\partial}{\partial t}\left(\rho v_{Y} V\right)+\frac{\partial}{\partial y}\left(\partial v_{Y}{ }^{2}\right)=-V \frac{\partial p}{\partial y}-F_{S}-F_{B}
$$

where

$v_{y}$ - velocity component of the fluid in $y$-direction

$F_{s}$ - Erictional Eorce in the y-direction

$F_{B}$ - gravitational body force in the $y$-direction

Since the mass flux, $G$, is equal to the product of velocity and density, equation $(A-4)$ can be written as,

$$
\frac{\partial}{\partial t}(G V)+V \frac{\partial}{\partial y}\left(\frac{G^{2}}{\rho}\right)=-\frac{V y E}{\partial y}-E_{S}-F_{B}
$$

Thus,

$$
\frac{\partial G}{\partial t}=\frac{-2 G \partial G}{\rho \partial y}-\frac{\partial p}{\partial Y}-\frac{F_{s}}{V}-\frac{m g}{V}
$$




\section{Energy Equation}

The energy equation is based on the first law of thermodynamics which states that energy cannot be created or destroyed.

For a control volume,

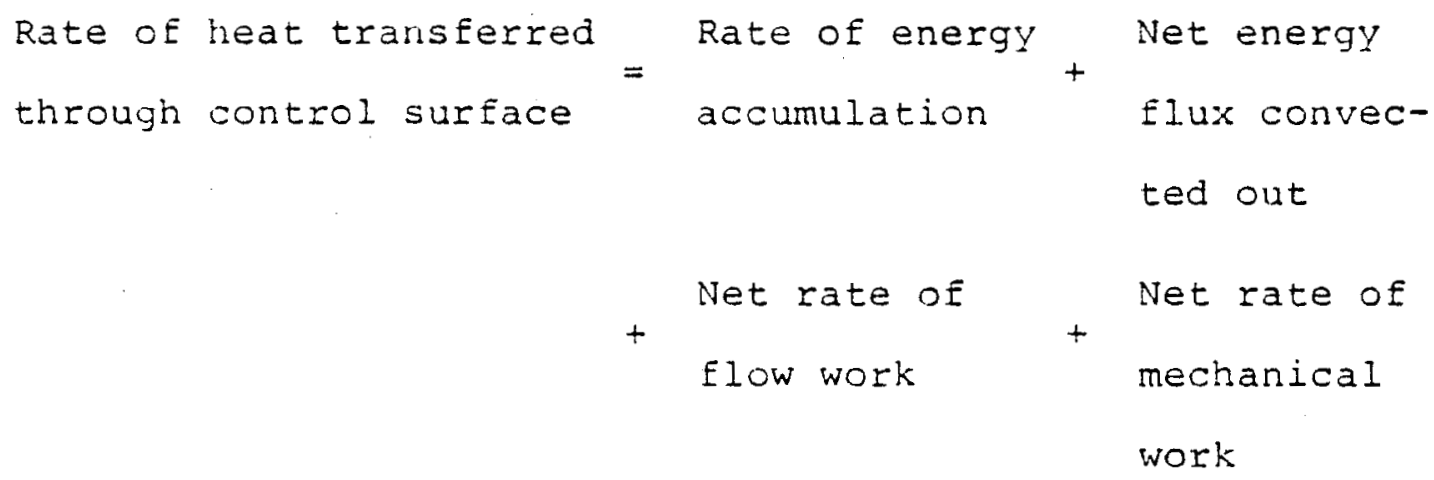

Thus,

$$
\begin{aligned}
\frac{d Q}{d t} & =\frac{\partial}{\partial t} \int_{V}^{\left(u+\frac{(\bar{G} V)^{2}}{2}\right)} p d V+\int_{A}\left(u+\frac{(\bar{G} V)^{2}}{2} p \vec{G} v \cdot d \bar{A}\right. \\
& +\int_{A} p(\bar{G} v) \cdot d \bar{A}+\frac{d W}{d t}
\end{aligned}
$$

where

$$
1 \text { - specific internal energy of the fluid, } \mathrm{J} / \mathrm{kg}
$$

Simplifying and collecting terms,

$$
\begin{aligned}
\frac{d Q}{d t} & =\frac{j}{3 t} \int_{V}\left(u+\frac{\left.(\bar{G} V)^{2}\right)}{2} p d V+\int_{A}\left((u+p v)+\frac{(\bar{G} V)^{2}}{2} \cdot d \bar{A}\right.\right. \\
& +\frac{d W}{d t}
\end{aligned}
$$


on applying Gauss' theorem to equation $(A-8)$,

$$
\begin{aligned}
\frac{d Q}{d t} & =\frac{j}{\partial t} \int_{V}\left(u+\frac{\left.(\bar{G} v)^{2}\right)}{2} p d V+\int_{V}^{\nabla}\left((u+p v)+\frac{\left.(\bar{G} V)^{2}\right)}{2} \bar{G} d V\right.\right. \\
& +\frac{d W}{d t}
\end{aligned}
$$

The specific enthalpy, $e=u+p v$

upon integrating, equation $(A-9)$ reduces to,

$$
\begin{aligned}
\frac{d Q}{d t} & =\frac{\partial}{\partial t}\left(u p V+\rho V \frac{\left.(\bar{G} V)^{2}\right)}{2}+V \nabla\left(\bar{G} e+\frac{\left.\bar{G}(\bar{G} V)^{2}\right)}{2}\right.\right. \\
& +\frac{d W}{d t}
\end{aligned}
$$

Thus,

$$
\frac{d Q}{d t}=\frac{\partial}{\partial t}\left(m u+\frac{\left.m(\bar{G} v)^{2}\right)}{2}+V \nabla\left(\bar{G} e+\frac{\left.\bar{G}(\bar{G} v)^{2}\right)}{2}+\frac{d W}{d t}\right.\right.
$$

where

$m$ - mass of the fluid, $\mathrm{kg}$

Simplifying equation (A-11) for a one-dimensional case,

$$
\begin{aligned}
\frac{d Q}{d t} & =\frac{\partial}{\partial t}\left(m u+\frac{\left.m(G V)^{2}\right)}{2}+\frac{v}{\partial y}\left(G e+\frac{\left.G(G V)^{2}\right)}{2}+\frac{d W}{d t}\right.\right. \\
\frac{d Q}{d t} & =\frac{\partial}{\partial t}(m u)+\frac{\partial}{\partial t}\left(\frac{\left.(G)^{2}\right)}{2}+\frac{V}{\partial y}(G e)+V \frac{\partial}{\partial y} \frac{\left(G(G V)^{2}\right)}{2}\right. \\
& +\frac{d v}{\partial t}
\end{aligned}
$$




$$
\begin{aligned}
\frac{d Q}{d t} & =\frac{\partial}{\partial t}(m L)+V \frac{\partial}{\partial y}(G e)+V \frac{\partial}{\partial t}\left(G^{2} v\right)-\frac{(G V)^{2}}{2} \frac{\partial m}{\partial t}+\frac{V}{\partial y}\left(G(G V)^{2}\right) \\
& +\frac{d W}{d t}
\end{aligned}
$$

Substituting the momentum and continuity equations, and simplifying,

$$
\begin{aligned}
& \frac{d Q}{d t}=\frac{\partial}{\partial t}(m u)+\frac{V}{\partial y}(G e)+G m v^{2}\left(-\frac{\partial}{\partial y}\left(\sigma^{2} v\right)-\frac{\partial p}{\partial y}\right)
\end{aligned}
$$

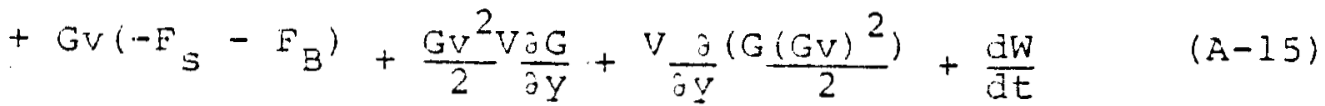

$$
\begin{aligned}
& \frac{d Q}{d t}=\frac{\partial}{\partial t}(m u)+V \frac{\partial}{\partial Y}(G e)-G V\left(V \frac{\partial}{\partial} \frac{P}{\partial}+F_{S}+m g\right)+\frac{d W}{d t}(A-16)
\end{aligned}
$$


APPENDIX B: SOLUTION OF MONENTUM AND ENERGY EQUATIONS

The method of determining the temperature and pressure distributions in the vapor and liquid pipes is presented in this section.

For a TGUC system, the simplified momentum and energy equations are

$$
\begin{gathered}
\frac{d p}{d y}=-\left[\frac{F}{v}+\frac{m g}{v}\right] \\
\dot{q}=V \frac{d}{d y}(G e)
\end{gathered}
$$

As shown in Eig. 4 (p. 12), the vapor and liquid pipes were broken up into a series of cells. For the vapor pipe the first cell was considered to be the boiler exit and therefore, all vapor properties in the first cell are known.

In order to numerically solve the momentum and energy equations, the temperature of the vapor in each cell was initialized to the boiler exit temperature. The pressure of the vapor in each cell was initialized to the pressure corresponding to that of a static column of the vapor.

The thermal resistance to heat flow from cell number 1 to the atmosphere was determined from emperical aata [18] and subseruentiy, the heat transferred out of the first cell was determined.

The total enthalpy of the vapor in the second cell was calculated from the enthalyg of the vapor in the first 
cell after deducting the heat transferred out of cell number 1. Thus, an updated temperature of the vapor in the second cell was determined.

The updated pressure of the vapor in the second cell was calculated using a finite difference form of the momentum equation, i.e. the pressure in cell number 2 is equal to the pressure in the first cell minus the pressure drop due to friction and the pressure drop due to the static column of vapor. The mass of the vapor in the second cell was then determined by the equation of state for an ideal gas, and the updated temperature and pressure. This process was repeated successively for each cell. The solution was terminated when the difference between the old and updated temperatures in each cell was less than $0.01^{\circ} \mathrm{F}$. 


\section{APPENDIX C: COMPUTER PROGRAM}

A flow chart and listing of the computer program used to simulate the Thermal Gradient Utilization Cycle are presented in this section. 


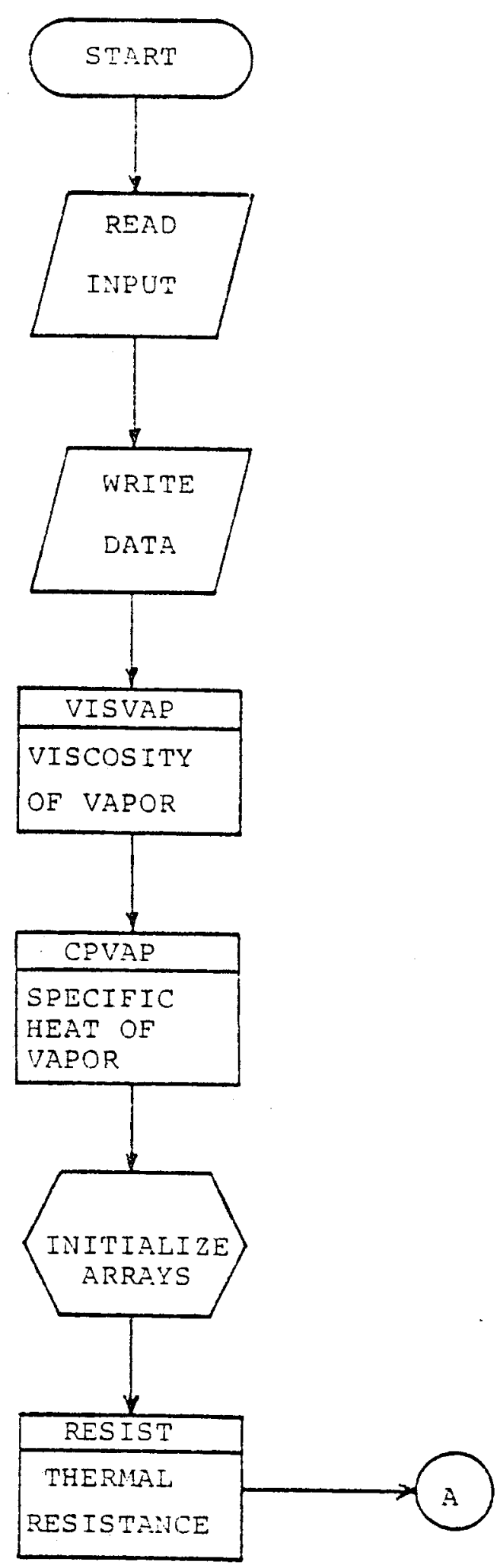

Fig. C-1. Flow chart of TGUC computer program 


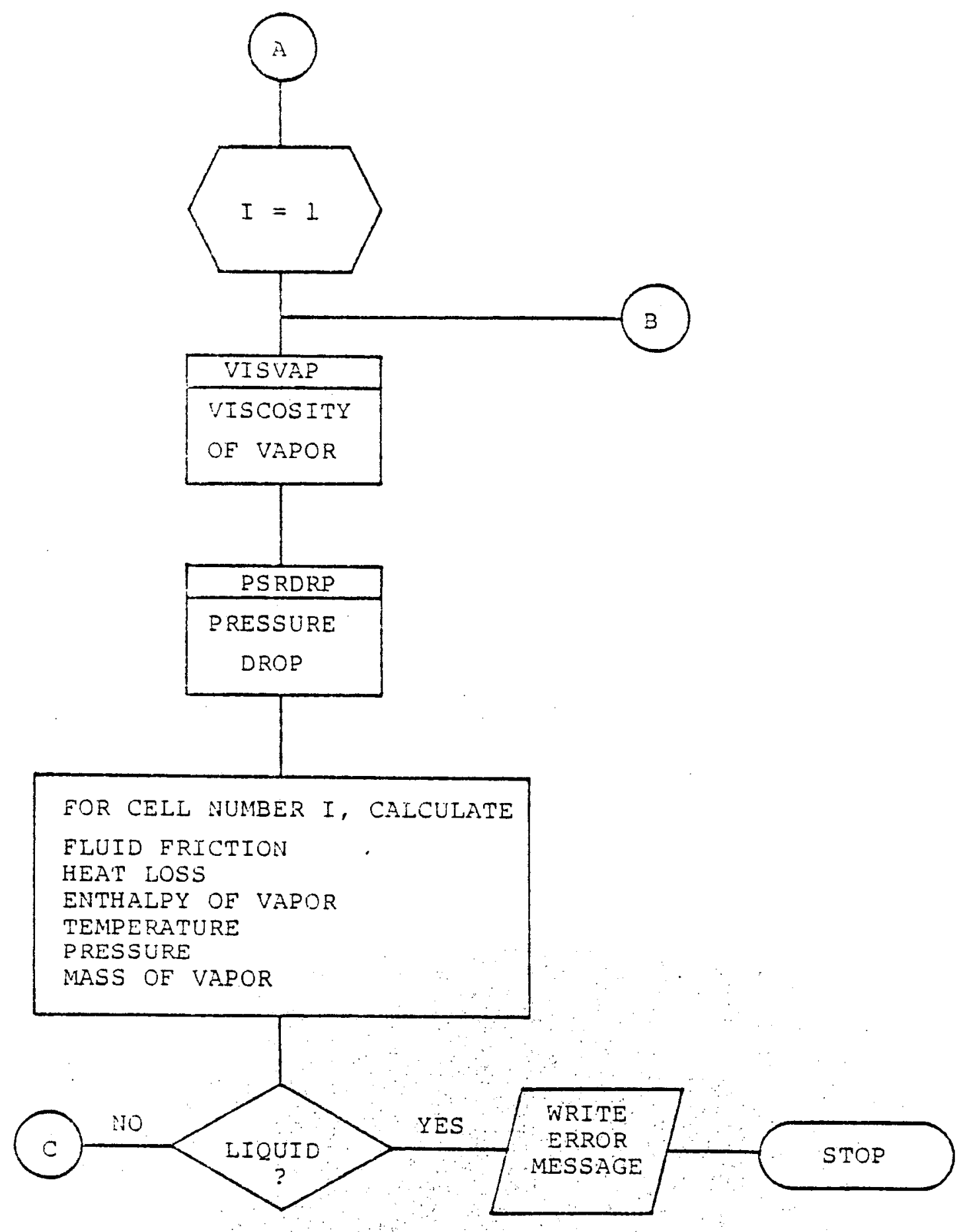

Fig. C-1 (continued) 


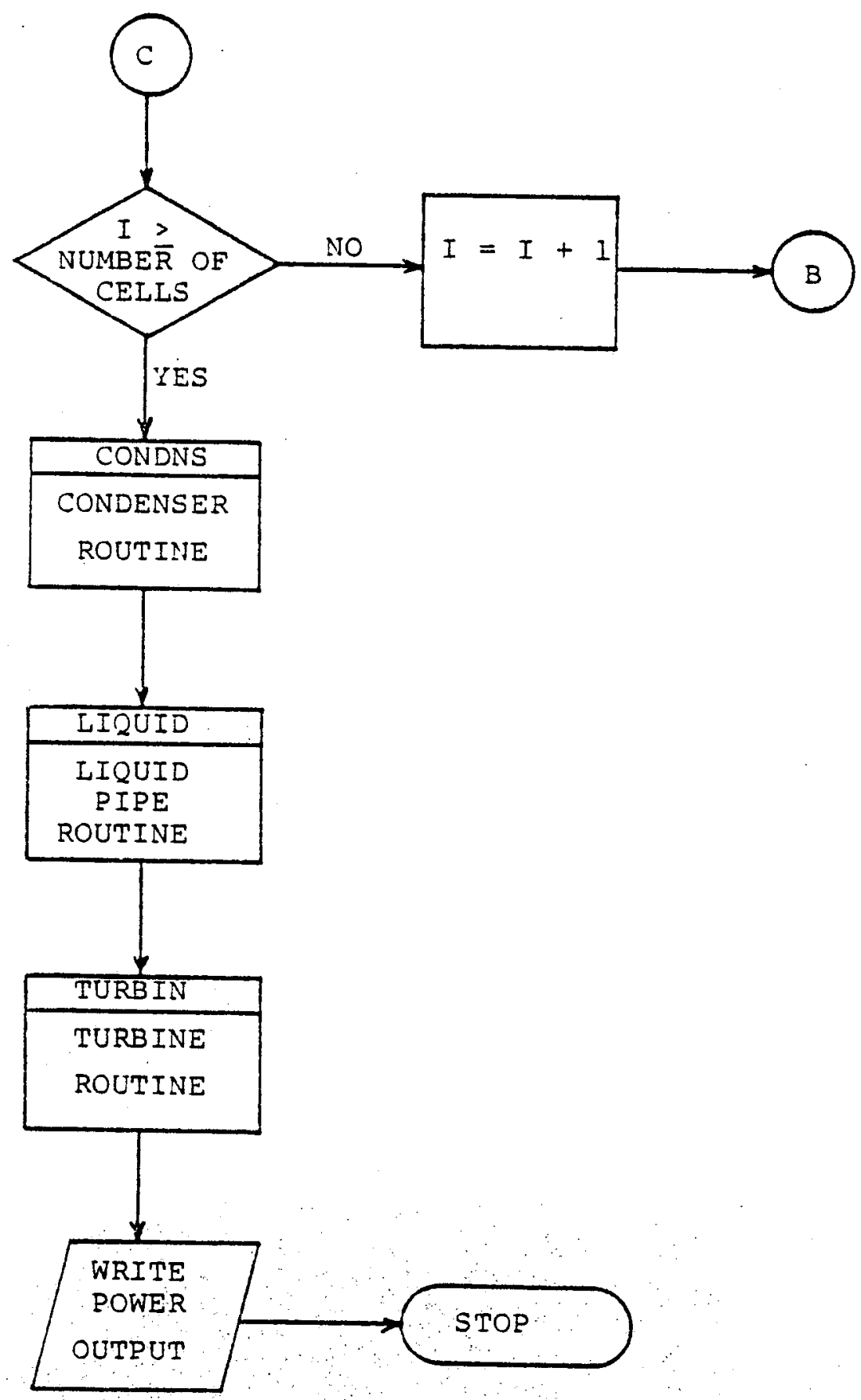

Fig. C-1 (continued) 
THIS PROGRAM SIMULATES THE OPERATION OF THE THERMAL GRADIENT UTILIZATION CYCLE. IT CALCULATES THE DISTRIBUTION OF PERTINENT VARIABLES IN THE VAPOR AND LIQUID PIPES AND PERFORMS A THERMODYNAMIC ANALYSIS OF THE CONDENSER AND HYDRAULIC TURBINE.

\section{INPUT VARIABLES:-}

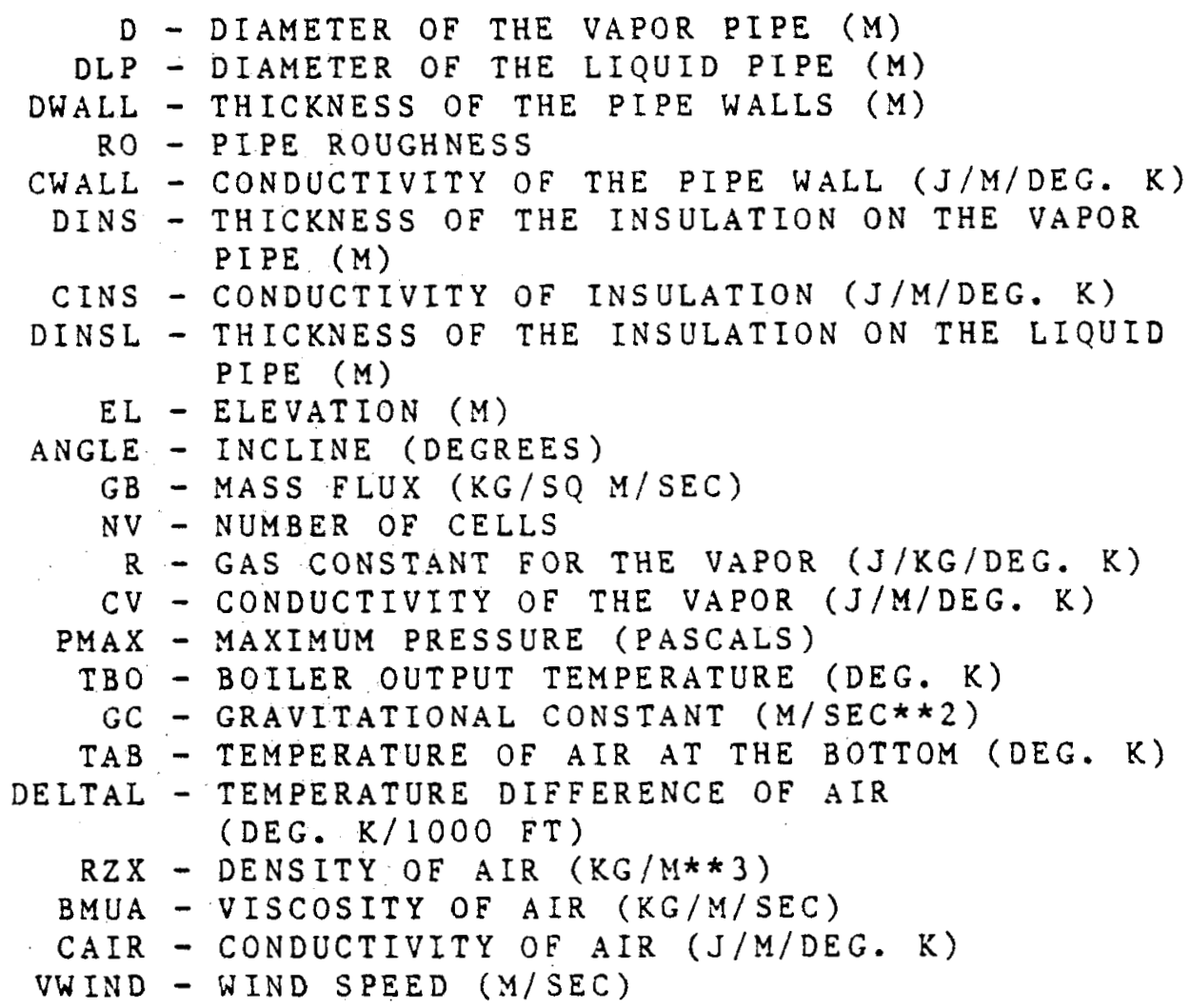

IMPLICIT REAL*8 $(\mathrm{A}-\mathrm{H}, 0-2)$

REAL* 4 VECT (9), PSP, SPACE $(9)$, PROPS $(9), \operatorname{PROPS} 2(9)$,

-PTOP, TEMPB, VALUE, TEMP 9 , TREFV

REAL*8, IDLP, KPI PE, KF (204)

DIMENSION VECTOR(9), TI (204), EE (204), PP(204), RMM(204), $-R M(204), P(204), E(204), E S(204), T(204)$, VSS (204), $-G(204), V S(204), D E L P(204), H(204), P F(204), F(204)$, - HIT (204), IFLO (204), TA (204), TSAT (204), HG(204), ROG (204), -DERG(204),DP(204), DM(204), HFS (204), HFGS (204), DQ (204)

COMMON/SHAFT/HEIGHT (204), ROF (204), RMUDE (204), KF -, CPE (204), PRF(204), PA (204), ROA(204), RMUDA(204), -VELF (204), HIN (204), REYNA (204), HOUT (204), RT(204), -Q(204), REYNF (204), QTOTAL, NMAX 
READ (5, 397) D, DLP, DWALL, RO, CWALL, DINS, CINS, DINSL

397 FORMAT ( 8 G 10.3)

READ (5, 398$)$ EL, ANGLE, GB, NV

398 FORMAT (3G10.3, I 3)

READ (5, 399). R, CV, PMAX, TBO, GC

399 FORMAT (5G10.3)

READ (5, 400) TAB, DELTAL, RZX, BMUA, CAIR, VWIND

400 EORMAT $(6610.3)$

$T A T=T A B-D E L T A L * E L / 304 . / 1.8$

WRITE $(6,401)$

401 FORMAT(' 1 ', $28 \mathrm{X}$, 'T H E R M A L G R A D I E N T',

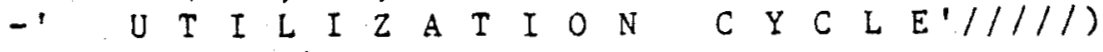

WRITE $(6,402) \quad D$

402 FORMAT(/5X,'DIAMETER OF THE VAPOR PIPE $=1$,

-G10.3,' METERS')

WRITE $(6,403)$ DLP

403 EORMAT( $/ 5 X$, 'DIAMETER OF THE LIQUID PIPE = ',

-G10.3,' METERS')

WRITE $(6,404)$ DWALL

404 EORMAT( $/ 5 X$,' THICKNESS OF THE PIPE WALL $=$ ',

-G10.3,' METERS')

WRITE $(6,405)$ RO, CWALL

405 FORMAT(/5X,'PIPE ROUGHNESS = ', G10.3//5X,

- 'CONDUCTIVITY OF THE PIPE WALL $=1, G 10.3$,

-' JOULES/METER/DEG. K')

WRITE $(6,406)$ DINS

406 FORMAT( $/ 5 X$,'THICKNESS OF INSULATION ON THE',

- 'VAPOR PIPE = ',GI0.3,' METERS')

WRITE $(6,407)$ CINS

407 FORMAT(/5X, CONDUCTIVITY OF THE INSULATION = , G10.3, - ' JOULES/METER - DEG. K') WRITE $(6,408)$ DINSL

408 FORMAT(/5X,'THICKNESS OF INSULATION ON THE ',

-'LIQUID PIPE $=$ ', GI0.3,'METERS')

WRITE $(6,409)$ EL

409 FORMAT (/5X,' ELEVATION = ', G10.3,'METERS') WRITE $(6,410)$ ANGLE

410 FORMAT $(/ 5 X$, INCLINE $=$, G10.3,' DEGREES $)$

WRITE $(6,411)$ GB

411 FORMAT $(15 X$, MASS ELUX $=$, GIO.3,' KG/SQ M/SEC.')

WRITE $(6,412), R, C V, P M A X$

412 FORMAT $/ 5 \times$, GAS CONSTANT $=, G 10.3,^{\circ} \mathrm{J} / \mathrm{KG} / \mathrm{DEG} .^{\prime}$ $-,{ }^{\prime} \mathrm{K}, 1 / 5 \mathrm{X},{ }^{\prime}$ CONDUCTIVITY OF VAPOR $={ }^{\prime}, \mathrm{J} 10.3,{ }^{\prime} \mathrm{J} / \mathrm{M}{ }^{\prime}$,

- - DEG.K'//5X, MAXIMUM PRESSURE = ',G10.3,' PA')

WRITE $(6,413)$ TBO

413 FORMAT $/ 5 X, 1$ BOILER OUTPUT TEMPERATURE = ' ,

$-G 10.3$, DEG. KO

WRITE $(6,415)$ TAB

415 FORMAT(/5X, TEMPERATURE OF AIR AT THE BOTTOM = '

-, G10.3, DEG. K')

WRITE $(6,416)$ DEITAL

416 FORMAT(/5X, TEMPERATURE DIEEERENCE OF AIR = , G10.3, 


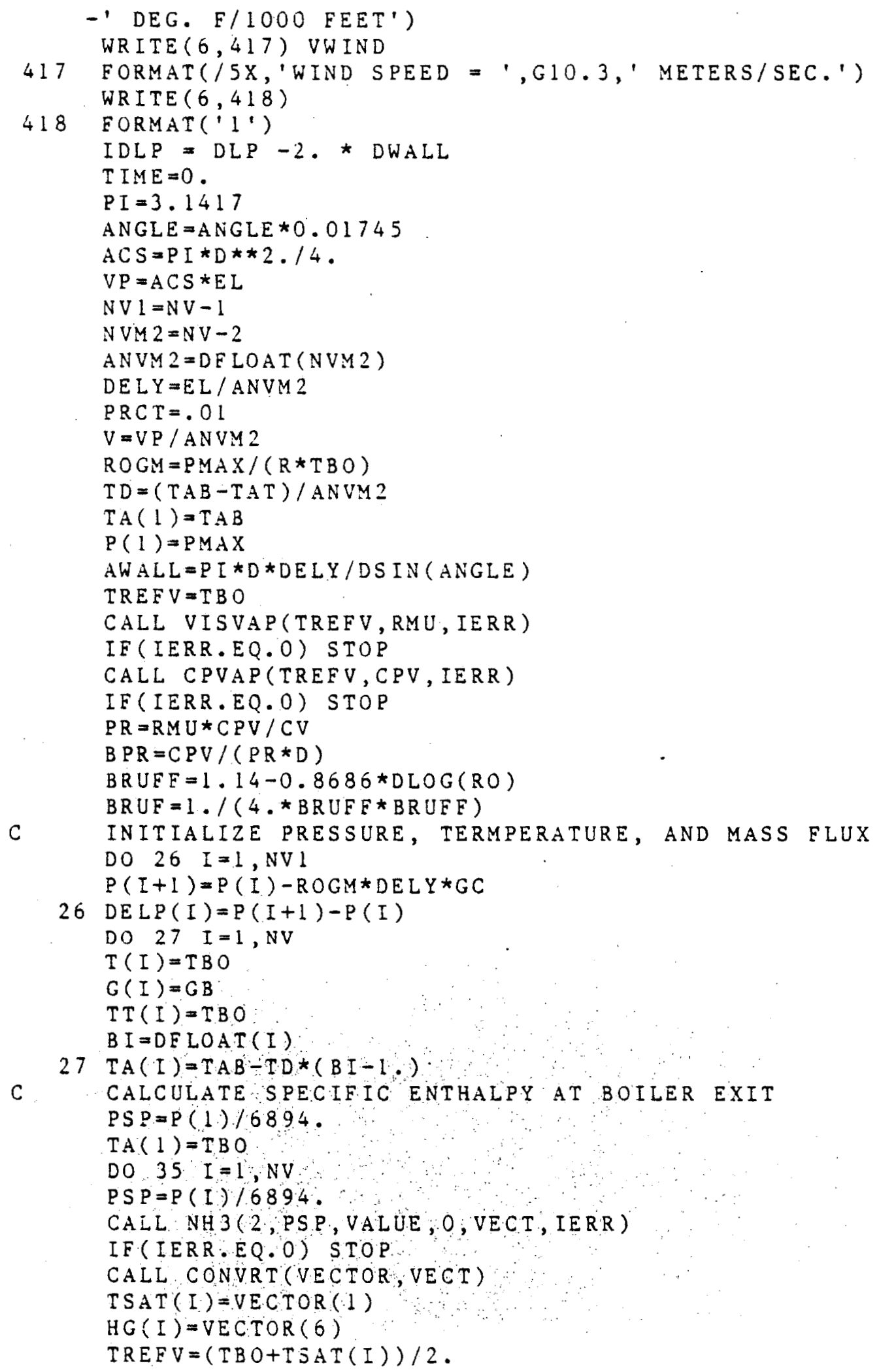




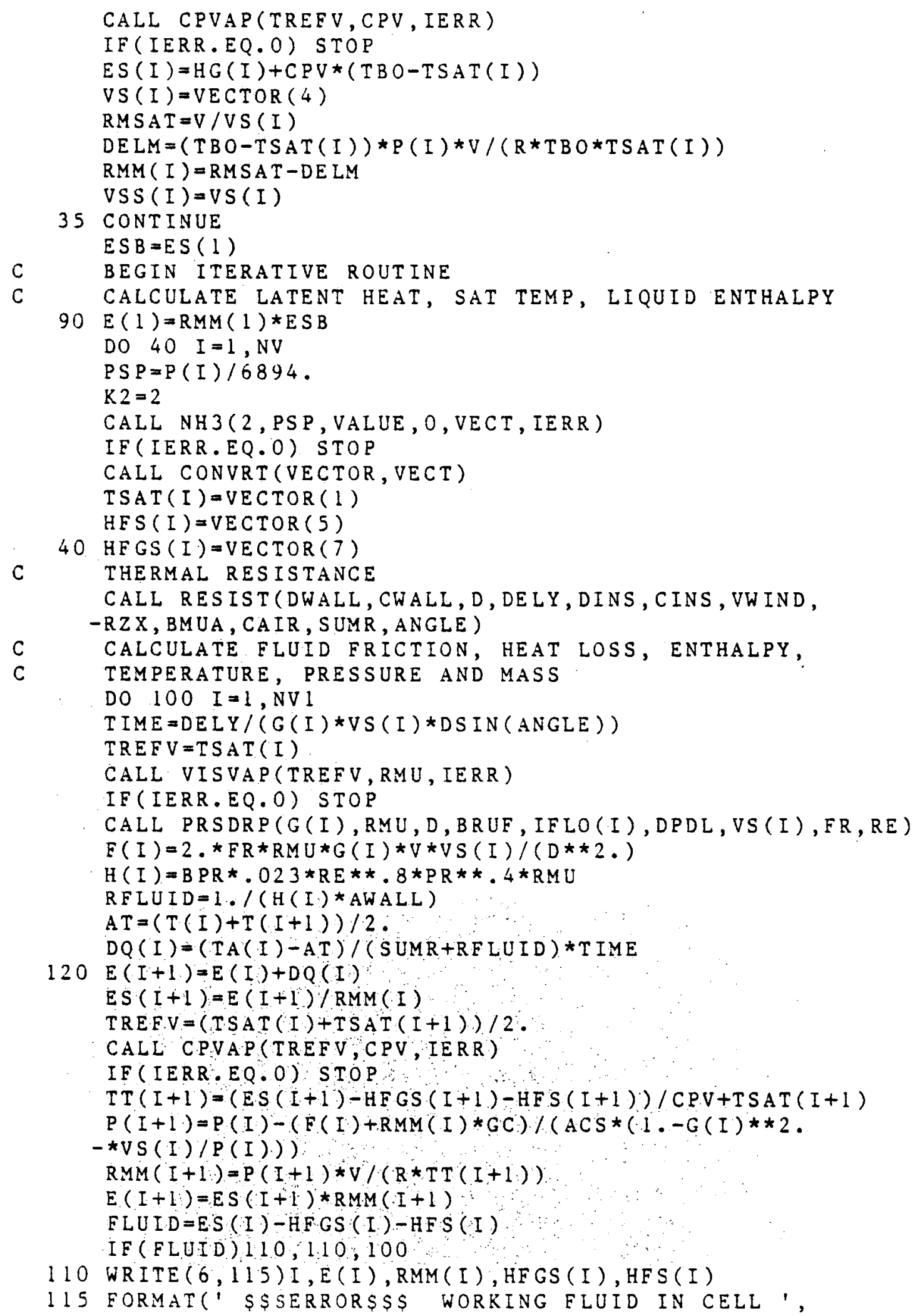




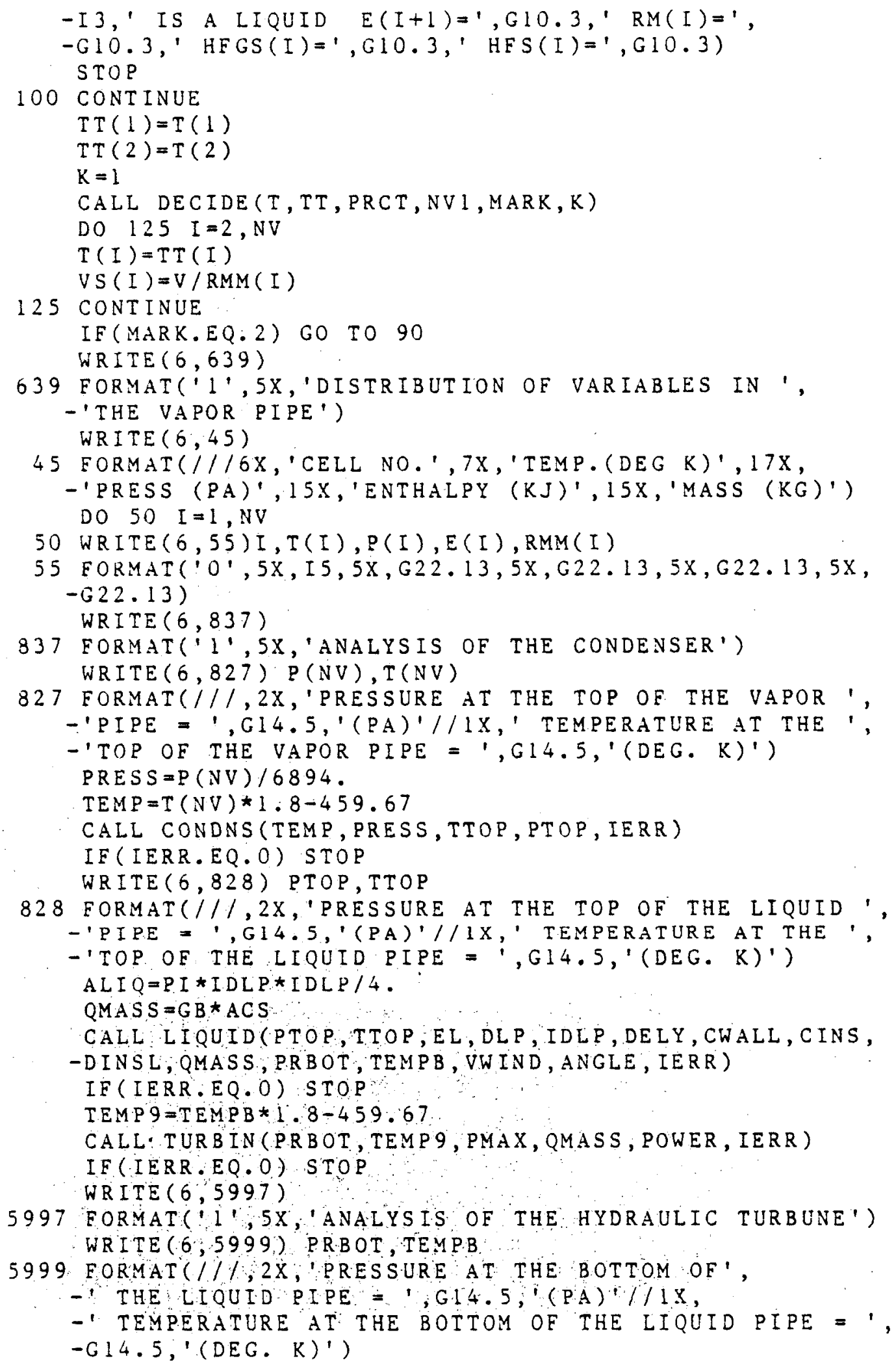




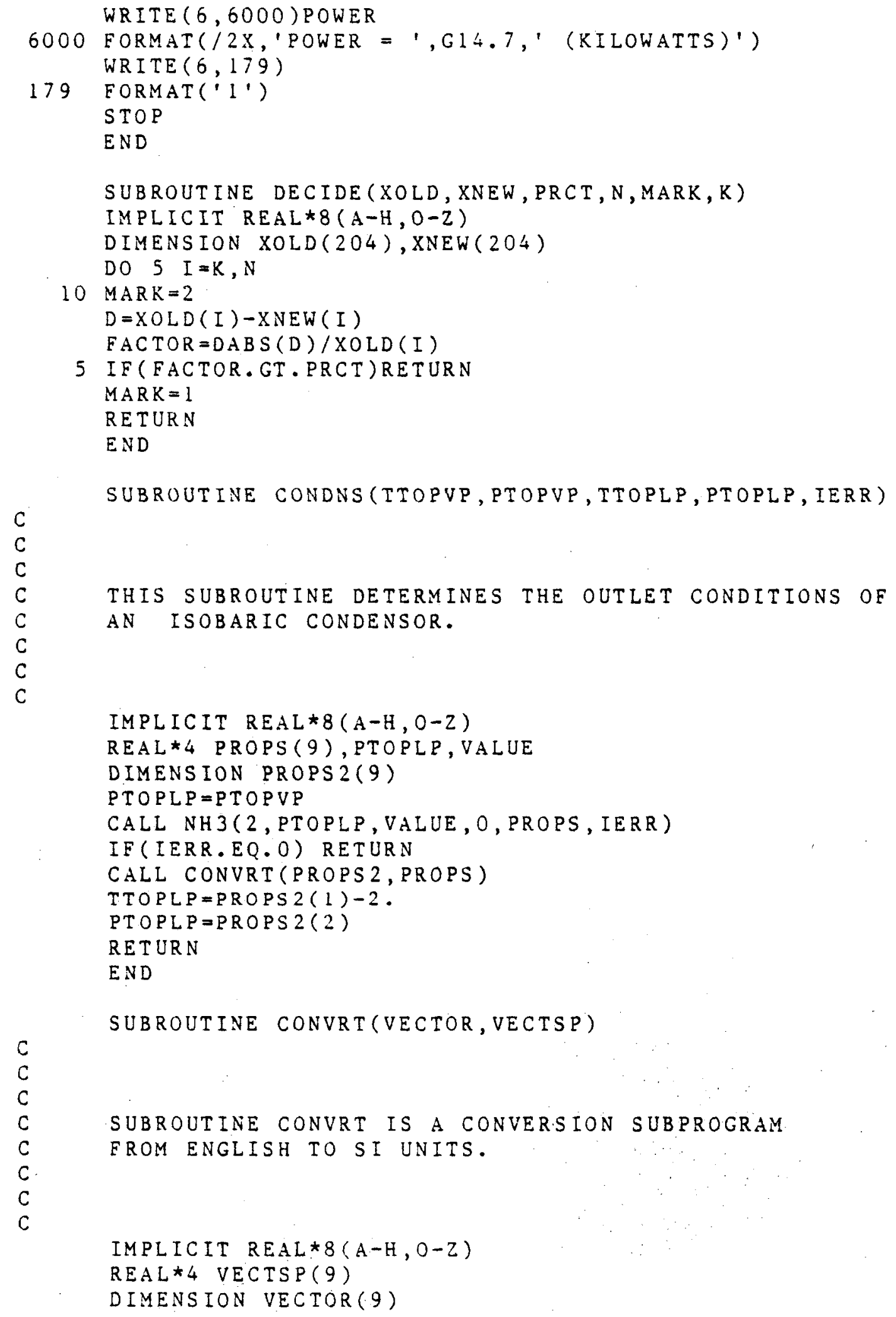


C TEMPERATURE FROM DEG.F TO DEG K

$$
\operatorname{VECTOR}(1)=(\operatorname{VECTSP}(1)+459.67) / 1.8
$$

C PRESSURE FROM PSI TO PASCALS VECTOR $(2)=V E C T S P(2) * 6894$.

C SPECIFIC VOLUME CU FT./LB. TO CU. M./KG $\operatorname{VECTOR}(3)=\operatorname{VECTSP}(3) * .062428$ VECTOR (4) =VECTSP $(4) * .062428$

C ENTHALPY OF FLUID FROM BTU/LBM TO J/KG VECTOR ( 5) =VECTSP ( S) *2326.

C ENTHALPY OF VAPORIZATION $\operatorname{VECTOR}(6)=\operatorname{VECTSP}(6) * 2326$.

C ENTHALPY OF GAS BTU/LBM TO J/KG VECTOR $(7)=\operatorname{VECTSP}(7) * 2326$.

C ENTROPY OF FLUID FROM BTU/LBM-DEG. R TO J/KG-DEG. K VECTOR $(8)=\operatorname{VECTSP}(8) \star 4186.816$

C ENTROPY OF GAS EROM BTU/LBM-DEG. R TO J/KG-DEG. K VECTOR $(9)=\operatorname{VECTSP}(9) * 4186.816$

RETURN

END

SUBROUTINE CON717(T, CONNH 3, IERR )

C

C

C

C

C

SUBROUTINE CON717 CALCULATES THE THERMAL CONDUCTIVITY (W/M-DEG. K) OF LIQUID REFRIGERANT 717

IF(T.LT.245.0.OR.T.GT.350.0) GO T0 999

$I E R R=1$

CONNH $3=1.1713-0.00231 * T$

RETURN

999 IERR $=0$

WRITE $(6,6) \quad T$

6 FORMAT (' 1 ', $5 X, ' \$ \$ \$ \$$ SEROR $\$ \$ \$ \$$ - TEMPERATURE OF',

-E 14.7,' DEG. K; IS OUT OF RANGE IN THERMAL',

- ' CONDUCTIVITY SUBPROGRAM')

RETURN

END

SUBROUTINE CP717(T, CPNH3, IERR)

C

$\mathrm{C}$

C

C

SUBROUTINE CP717 CALCULATES THE SPECIFIC HEAT CAPACITY FOR CONSTANT PRESSURE (J/KG-DEG.K) FOR LIQUID REFRIGERANT 717

IF(T.LT.195.0.OR.T.GT.380.0) GO TO 999 


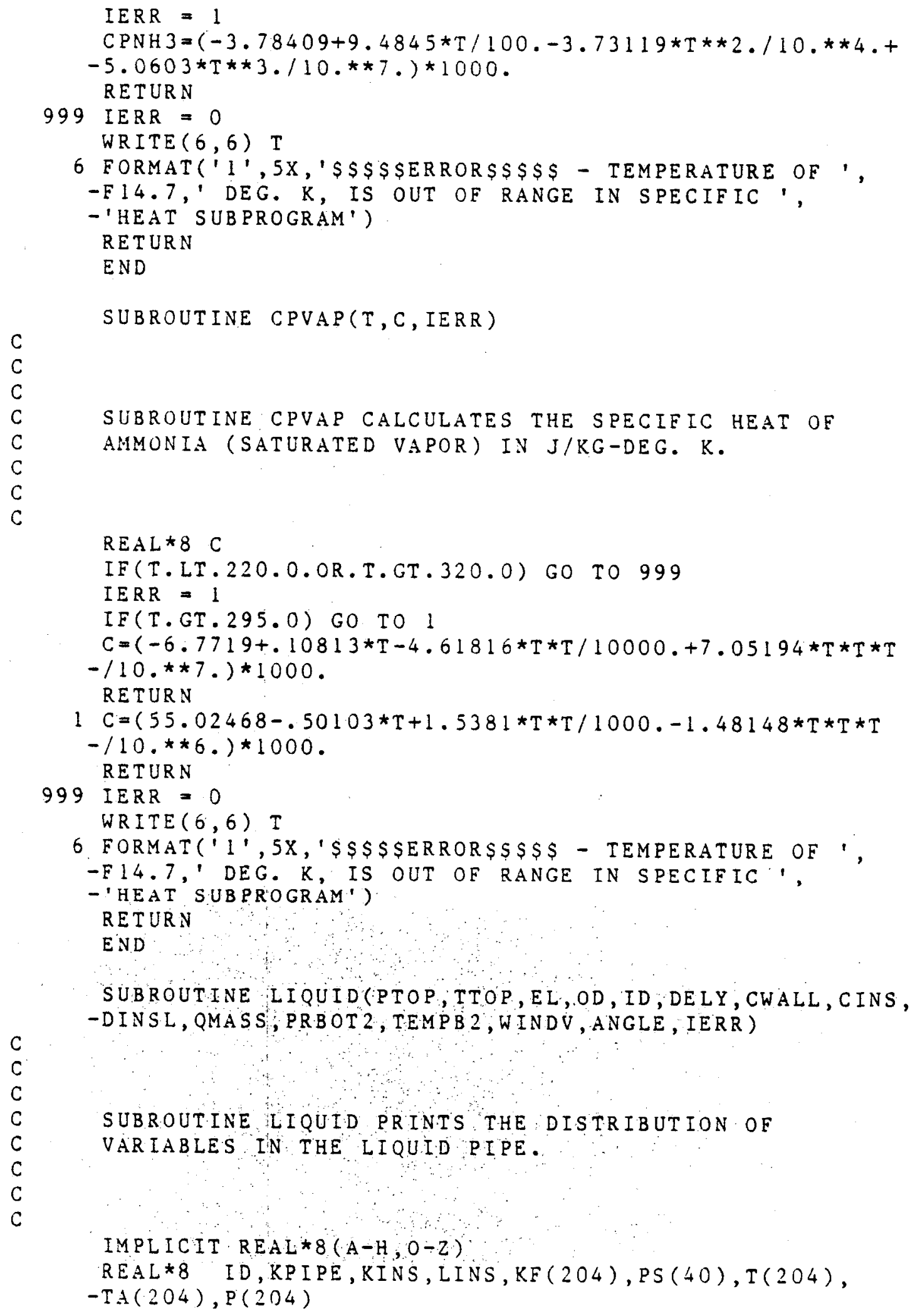


REAL* 4 VECTOR( 9 ), TT, PSS (40), PTOP, TEMPB 2

INTEGER HTDIN

COMMON/SHAFT/HEIGHI (204), ROE ( 204 ), RMUDF ( 204 ), KF

-, CPF(204), PRE(204), PA(204), ROA(204), RMUDA(204),

-VELF (204), HIN (204), REYNA (204), HOUT(204), RT(204),

-Q(204), REYNF(204), QTOTAL, NMAX

$\mathrm{SLH}=0$.

CALL DWNSHT (PTOP, TTOP, EL, SLH, OD, ID, DELY, CWALL, CINS,

-DINSL, QMASS, T, TA, P, WINDV, ANGLE, IERR)

IF (IERR.EQ.0) RETURN

HTDIN $=$ NMAX

PRBOT $2=P($ HTDIN )

TEMPE? $=T($ HTDIN $)$

$\mathrm{K}=1$

$\mathrm{L}=2$

DO $150 \mathrm{~N}=1$, NMAX

$\mathrm{T} T=\mathrm{T}(\mathrm{N}) * 9 / 5-459.67$

CALL NH3 (K, TT, PSS (N), L, VECTOR, IERR)

IF (IERR.EQ.O) RETURN

$\operatorname{PS}(N)=\operatorname{PSS}(N) * 6894.76$

150 CONTINUE

IF $(P(N)-P S(N)) 151,151,49$

151 WRITE $(6,120)$

120 FORMAT ('O','\$\$\$FLUIDS HAS FLASHED INTO VAPOR\$\$\$') STOP

49 WRITE $(6,50)$

50 FORMAT(' 1 ', $5 X$, 'DISTRIBUTION OF VARIABLES IN THE', - 'THE LIQUID PIPE'//)

WRITE $(6,51)$

51 FORMAT ( $0^{\prime}, 65 \mathrm{X}, 13$ HSPECIFIC HEAT)

WRITE $(6,52)$

52 FORMAT $(', 47 \mathrm{X}, 7$ HDYNAMIC, $11 \mathrm{X}, 12 \mathrm{HCAPACITY}$ FOR, $7 \mathrm{X}$, -7HPRANDTL, 29X, 8HREYNOLDS)

WRITE $(6,53)$

53 FORMAT (' ', 2X, 4HTEMP, 6X, 5HPRESS, 6X, 6HHEIGHT, 4X,

-7HDENSITY, 7X, 9HVISCOSITY, 9X, 14 HCONSTANT PRESS, $5 X$,

-6HNUMBER, $11 X, 8$ HVELOCITY, $12 X, 6$ HNUMBER) WRITE $(6,54)$

54 FORMAT (, $7 \mathrm{H}$ (DEG.K), 4X,9H (PASCALS), $2 \mathrm{X}, 8 \mathrm{H}$ (METERS), $-2 \mathrm{X}, 9 \mathrm{H}(\mathrm{KG} / \mathrm{CU} . \mathrm{M}), 5 \mathrm{X}, 10 \mathrm{H}(\mathrm{N}-\mathrm{S} / \mathrm{SQ} . \mathrm{M}), 9 \mathrm{X}, 12 \mathrm{H}(\mathrm{J} / \mathrm{KG}-\mathrm{DEG} . \mathrm{K})$, $-24 \mathrm{X}, 9 \mathrm{H}(\mathrm{MET} / \mathrm{SEC}))$

WRITE $(6,55)$

55 FORMAT $(.0 ')$

DO $56 \mathrm{~N}=1, \mathrm{HTDIN}$

56 WRITE $(6,57) \mathrm{T}(\mathrm{N}), \mathrm{P}(\mathrm{N}), \operatorname{HEIGHT}(\mathrm{N}), \operatorname{ROF}(\mathrm{N}), \operatorname{RMUDF}(\mathrm{N}), \operatorname{CPF}(\mathrm{N})$ ,$- \operatorname{PRF}(\mathrm{N})$, VELF (N), REYNF(N)

57 FORMAT ( ', 1X,F6.2,2X,F $11.2,2 X, E 7.2,3 X, F 7.2,5 X, E 14.6$

$-, 6 \mathrm{X}, \mathrm{E} 13.6,5 \mathrm{X}, \mathrm{E} 13.6,4 \mathrm{X}, \mathrm{E} 13.6,7 \mathrm{X}, \mathrm{E} 13.6 \%)$ WRITE $(6,60)$

60 FORMAT (1 , $2 \times$, PROPERTIES OF AIR AND HEAT ELOW $/ / /)$ WRITE $(6,61)$

61 FORMAT(' ',5OX, 11 HINSIDE HEAT, 24X, 12 HOUTSIDE HEAT/51X, 
-8HTRANSFER, 9X, 8HREYNOLDS , 10X, 8HTRANSFER, 9X, 5HTOTAL) $\operatorname{WRITE}(6,62)$

62 FORMAT(' ', 2X, 4HTEMP, 5X, 5HPRESS, 6X, 7HDENS ITY, 4X, -9HVIS COSITY, 8X, 11 HCOEFE ICIENT, 6X, 6HNUMBER, $12 X$,

- 11 HCOEFFICIENT, 6X, 10HRES ISTANCE, 3X, 9HHEAT FLOW) WRITE $(6,63)$

63 FORMAT (' ', 7H(DEG.K), 2X, 9H(PASCALS), 3X, 9H(KG/CU.M), 3X, $-10 \mathrm{H}(\mathrm{N}-\mathrm{S} / \mathrm{SQ} \cdot \mathrm{M}), 6 \mathrm{X}, 14 \mathrm{H}(\mathrm{W} / \mathrm{SQ} \cdot \mathrm{M} * \mathrm{DE} \cdot \mathrm{K}), 22 \mathrm{X}$,

$-14 \mathrm{H}(\mathrm{W} / \mathrm{SQ} . \mathrm{M} / \mathrm{DEG} . \mathrm{K}), 3 \mathrm{X}, 9 \mathrm{H}(\mathrm{DEG} . \mathrm{K} / \mathrm{M}), 4 \mathrm{X}, 7 \mathrm{H}$ (WATTS))

WRITE $(6,64)$

64 FORMAT $\left(! 0^{\prime}\right)$

DO $65 M=1$, HTDIN

65 WRITE $(6,66) \operatorname{TA}(M), \operatorname{PA}(M), \operatorname{ROA}(M), \operatorname{RMUDA}(M), H I N(M)$,

-REYNA(M), HOUT (M), RT (M), Q (M)

66 FORMAT(' $', 1 X, E 6.2,2 X, F 11.2,2 X, E 10.3,2 X, E 11.4,3 X$,

-E 15.7, 3X,E14.7, 4X,E15.7, 3X, E 8.3, 4X,E14.7/)

WRITE $(6,67)$ QTOTAL

67 FORMAT( $0^{\prime}, / / / 5 \mathrm{X}, 18 \mathrm{HTOTAL}$ HEAT FLOW $=, \mathrm{E} 14.7,3 \mathrm{X}$,

$-7 H($ WATTS ))

RETURN

END

SUBROUTINE DWNSHT (PRESS, TEMP, H1, H2, OD, ID, DELY, KPIPE, -KINS, LINS , G, T, TA, P, VELA, ANGLE, IERR)

$\mathrm{C}$

C

C

C

C

C

C

C

C

C

C

C

C

C

C

C

C

C

C

C

C

C

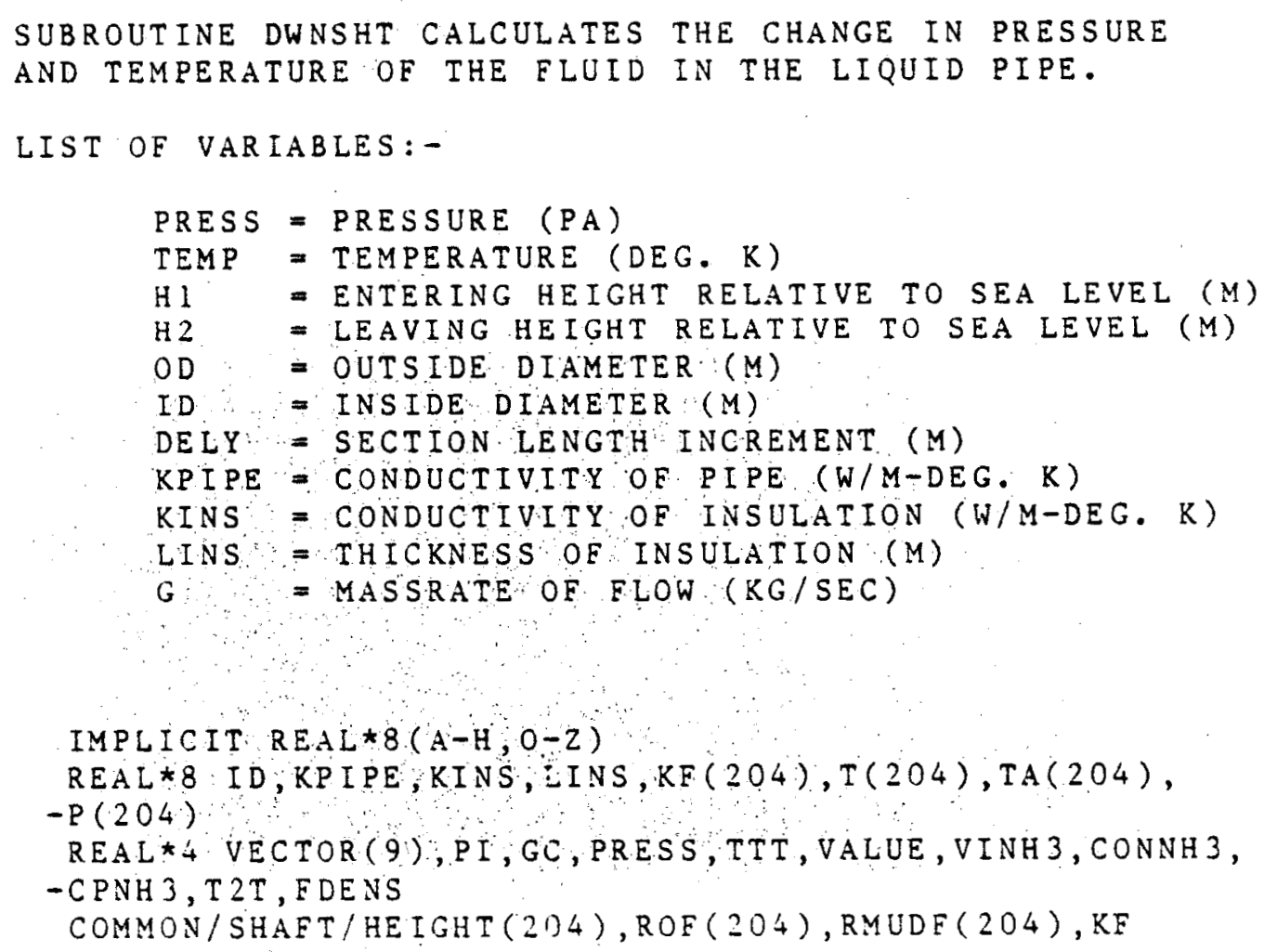


-, CPF (204), PRF(204), PA(204), ROA(204), RMUDA(204),

-VELF(204), HIN (204), REYNA(204), HOUT(204), RT(204),

-Q(204), REYNF( 204$)$, QTOTAL, NMAX

DATA PI/3.141593/,GC/9.80665/

$C S A R E A=P I * I D * I D / 4.0$

$V=C S A R E A * D E L Y / D S I N(A N G L E)$

C

RESISTANCE OF PIPE AND INSULATION ( $D E G . \mathrm{K} / \mathrm{W}$ )

$R P I P E=D L O G(O D / I D) /(K P I P E * 2.0 * P I * D E L Y / D S I N(A N G L E))$

RINS $=$ DLOG $(1+2.0 *$ LINS /OD $) /($ KINS $2.0 * P I * D E L Y /$

-DS IN (ANGLE))

QTOTAL $=0.0$

$N=1$

$T(N)=T E M P * 1$.

$\operatorname{HEIGHT}(\mathrm{N})=\mathrm{H} \mathrm{I}$

C

$P(N)=$ PRESS* 1 .

C

C

C

C

C

c

C

$10 \operatorname{TTT}=\mathrm{T}(\mathrm{N}) * 1.8-459.67$

CALL NH3( 1, TTT, FDENS, 3, VECTOR, IERR)

IF (IERR.EQ.0) RETURN

$\operatorname{ROF}(N)=16.0167 / F D E N S$

$T 2 T=T(N)$

CALL VIS 717 (T 2T, VINH 3, IERR)

IF (IERR.EQ.0) RETURN

$\operatorname{RMUDF}(\mathrm{N})=\operatorname{VINH} 3$

CALL CON717(T2T, CONNH 3, IERR)

IF (IERR.EQ.0) RETURN

$\mathrm{KF}(\mathrm{N})=\mathrm{CONNH} 3$

CALL CP 717 (T2T, CPNH 3, IERR)

IF (IERR.EQ.0) RETURN

$C P F(N)=C P N H 3$

$\operatorname{PRF}(N)=C P F(N) * \operatorname{RMUDF}(N) / K F(N)$

CALCULATE PROPERTIES OF AIR AT HEIGHT (N)

TA = TEMPERATURE OF AMBIENT AIR (DEG.K)

PA = PRESSURE OF AMBIENT AIR (PA)

ROA = DENSITY OF AMBIENT AIR (KG/CU,M)

RMUDA = VISCOSITY OE AMBIENT AIR (N-S/SQ. M)

THE VISCOSITY OF AIR IS CALCULATED USING THE EQUATION IN "THERMOPHYSICAL PROPERTIES OF REERIGERANTS", 1976 ASHRAE PAGE I 71 .

$\operatorname{TA}(\mathrm{N})=301.00-.0026100 * \mathrm{HEIGHT}(\mathrm{N})$

$P A(N)=101325-10.37185 *$ HEIGHT $(N)$

$\operatorname{ROA}(\mathrm{N})=9.827189 \mathrm{E}-4-8.415012 \mathrm{E}-8 * \mathrm{HEIGHT}(\mathrm{N})$ 


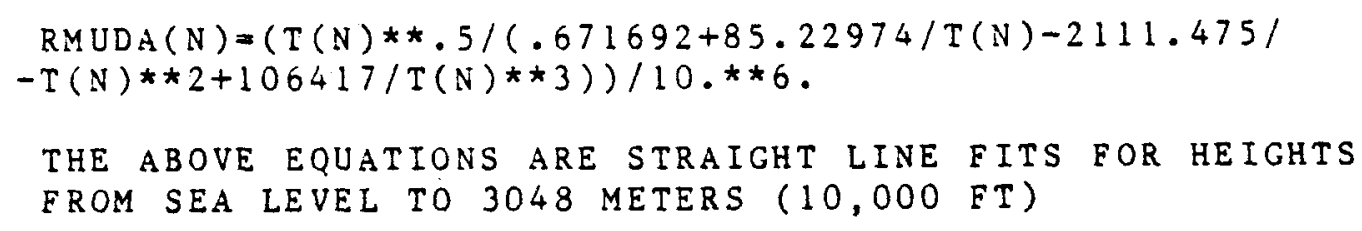




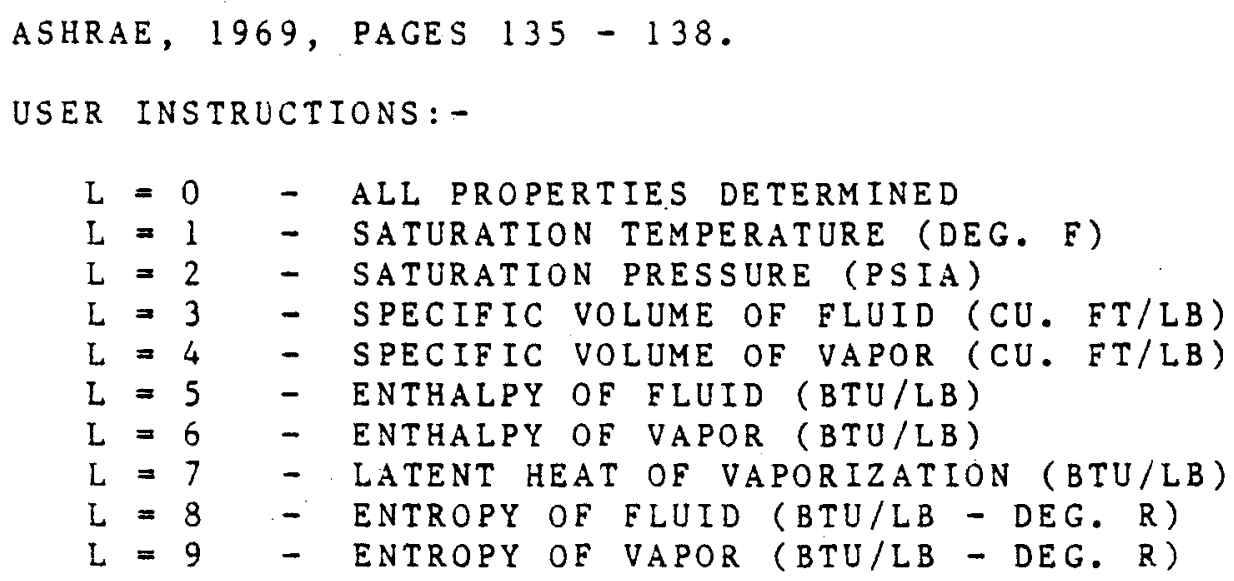

IF L IS NOT EQUAL TO ZERO, THE VALUE OF THE PROPERTY IS RETURNED AS "VALUE".

IF L IS EQUAL TO ZERO, THE PROPERTIES ARE STORED IN THE ARRAY "VECTOR" AS FOLLOWS:-

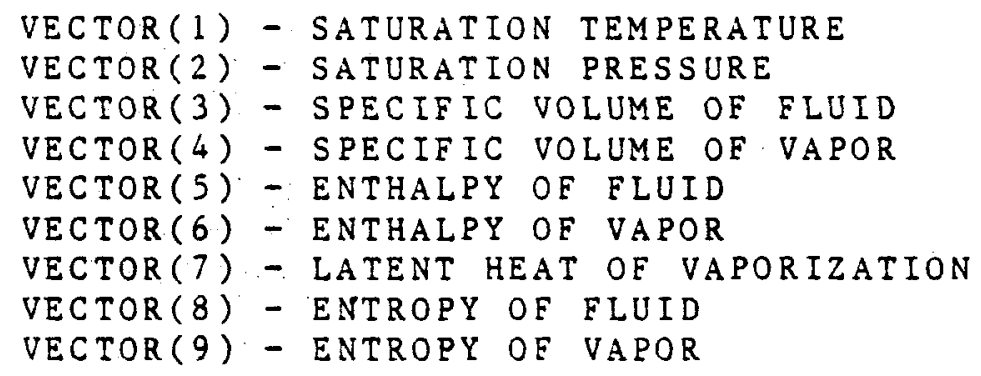

NOTE : IERR IS AN ERROR CODE.

IERR $=0$ INDICATES AN ERROR

IERR $=1$ INDICATES NO ERRORS

DIMENSION A $(35,9), B(35), C(35), D(35), E(35), F(35)$,

$-G(35), H(35), P(35), Q(35), V E C T O R(9)$

EQU IVALENCE $(A(1,1), B),(A(1,2), C),(A(1,3), D)$,

$-(A(1,4), E),(A(1,5), F),(A(1,6), G),(A(1,7), H)$,

$-(A(1,8), P),(A(1,9), Q)$.

DATA B $/-45,-40,-35,-30,-25,-20,-15,-10,,-5,, 0 .$,

$-5 ., 10,, 15,, 20,, 25,, 30,, 35,, 40,45,, 50,, 55,, 60,, 65,, 70$.

$-, 75 \cdot, 80 ., 85,, 90,95,, 100,, 105,110,, 115 \%, 120 ., 125.1$

DATA C/8.95,10.41,12.05,13.90,15.98,18.30,20.88,23.74, $-26.92,30.42,34.27,38.51,43.14,48.21,53.73,59.74,66.26$, $-73.32,80.96,89.19,98.06,107.6,117.8,128.8,140.5,153.0$, $-166.4,180.6,195.8,211.9,228.9,247.0,266.2,286.4,307.8 /$ DATA D/0.02310,.02322,.02333,.02345,.02357,.02369, 


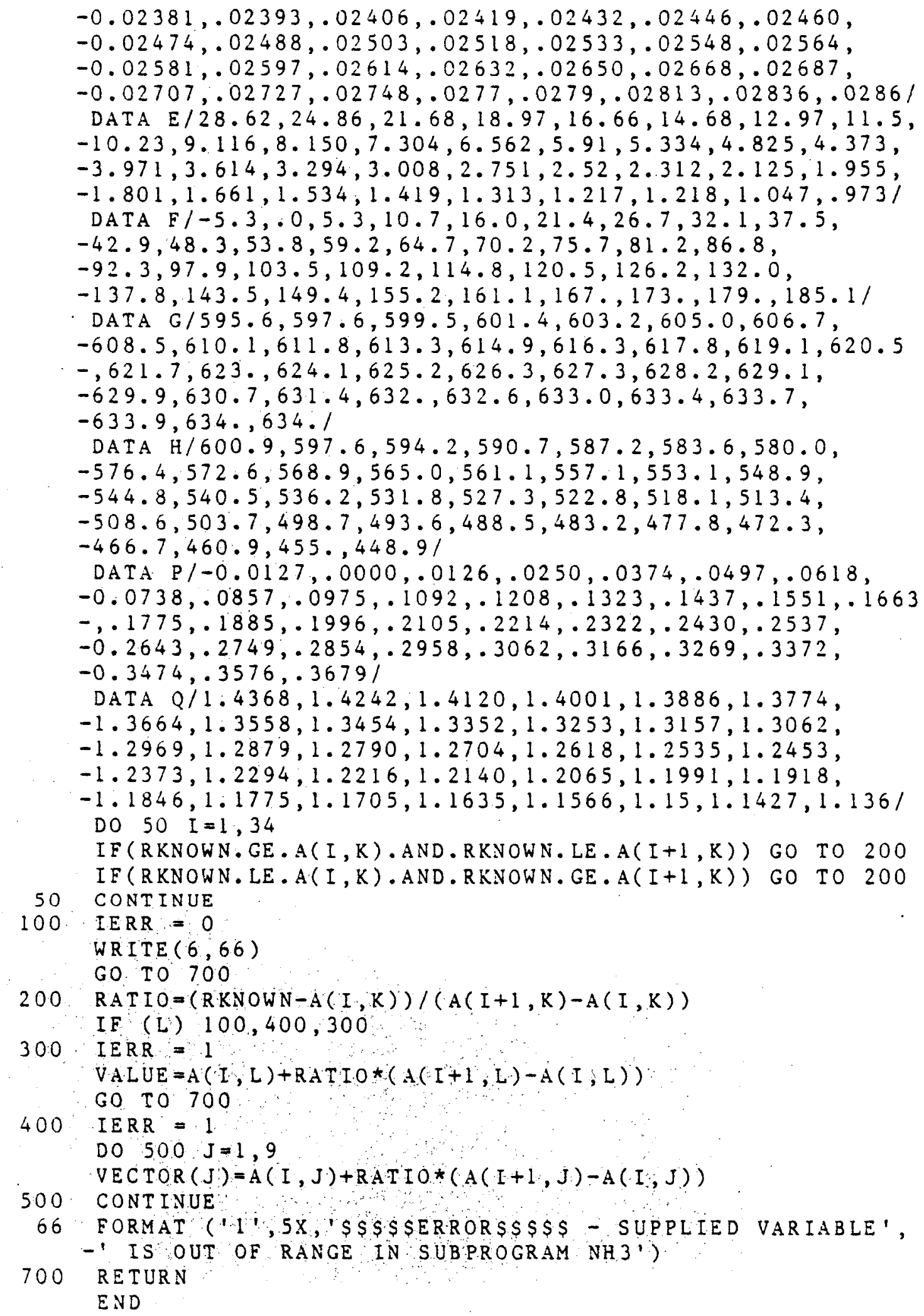


SUBROUTINE PRSDRP( $G, R M U, D, B R U F$, IFLO, DPDL, VSN, FR, RE)

C

$\mathrm{C}$

C

SUBROUTINE PRSDRP CALCULATES THE PRESSURE DROP PER UNIT LENGTH OF PIPE FOR A GIVEN MASS FLOW RATE, VISCOSITY, DIAMETER AND PIPE ROUGHNESS.

C

C

C

C

IMPLICIT REAL*8(A-H,O-Z)

IF (RMU) 1, 1, 2

1 DPDL $=0$.

IF $L O=1$

RETURN

$2 R E=D A B S(G * D / R M U)$

$F R=16$.

$I F L O=1$

IF (RE-2000.)20,5,5

$5 \quad F R I=.0791 * R E * \star .75$

$F R 2=B R U F * R E$

IF(FR2-FR1) 10,15,15

$10 \quad F R=F R 1$

IF LO $=2$

GO TO 20

$15 \quad F R=F R 2$

IF LO $=3$

20 CONTINUE

$D P D L=-2 . * F R * R M U * G * V S N /(D * D)$

RETURN

END

SUBROUTINE RESIST(LWALL, KWALL, D, DELY, LINS, KINS, -VWIND, ROA, BMUA, KA IR, SUMR, ANGLE)

SUBROUT INE RESIST CALCULATES THE RESISTANCE TO HEAT FLOW ALONG THE PIPE WALL EXCEPT FOR THE RESISTANCE DUE TO CONVECTION INSIDE THE PIPE.

IMPLICIT REAL*8 $(\mathrm{A}-\mathrm{H}, \mathrm{O}-\mathrm{Z})$

REAL*8 LWALL, KWALL, LINS, KINS, KAIR

DOUT $=D+2 . *$ (LWALL+LINS)

$P I=3.141592654$

$A O U T=D O U T * P I * D E L Y / D S I N(A N G L E)$

$A=P I * D * D E L Y / D S I N(A N G L E)$

$A A V G=(A O U T+A) / 2$.

RWALL $=L W A L L /(K W A L L * A)$

RINS $=$ LINS/(KINS *AAVG) 
$R E W=R O A * V W I N D * D O U T / B M U A$

HOUT $=(.43+.48 * \mathrm{REW} * * .5) * \mathrm{KAIR} / \mathrm{DOUT}$

RWIND $=1 . /($ HOUT *AOUT )

$S U M R=R W A L L+R I N S+R W I N D$

RETURN

END

SUBROUTINE TURBIN (PBOTLP, TBOTLP, PMAX, MFLUX, POWER, IERR)

C

$\mathrm{C}$

$\mathrm{C}$

C

C

C

$\mathrm{C}$

C

C

C

SUBROUTINE TURBin CALCUlates THE POWER OUTPUT (KW) FOR A HYDRAULIC TURBINE.

NOTE - THE WORKING FLUID IS ASSUMED TO BE INC OMPRESS IBLE.

IMPLICIT REAL*8(A-H,O-Z)

REAL $* 8$ MFLUX

REAL*4 SPACE (9); TBOTLP, SPVOL

CALL NH3 ( 1, TBOTLP, SPVOL, 3, SPACE, IERR)

IF (IERR,EQ.0) RETURN

$R O E=S P V O L * 0.062428$

DELTAP $=P$ BOTLP $-P M A X$

POWER $=M F L U X * D E L T A P * R O E / 1000$.

RETURN

END

$\mathrm{C}$

SUBROUTINE VIS 717 (T, VISNH 3, IERR)

C

$\mathrm{C}$

$\mathrm{C}$

C

C

$\mathrm{C}$

$\mathrm{C}$

SUBROUTINE VIS 717 CALCULATES THE DYNAMIC VISCOSITY (N-S/SQ.M) OF LIQUID REFRIGERANT 717

IF(T.LT.240.0.OR.T.GT.390.0) GO TO. 999

$I E R R=1$

VISNH $3=\operatorname{EXP}(-7.9732+2614.41 / T-243288 . / T * * 2) /$. RETUR N

999 IERR $=0$

WRITE $(6,6)$ T

6 EORMAT ('1',5X,'\$\$\$\$ERROR\$\$\$\$ - TEMPERATURE OF',

-F 14.7, DEG. K, IS OUT OF RANGE IN VISCOSITY',

- 'SUBPROGRAM')

RETURN

END

c.

SUBROUTINE VISVAP(T, V; IERR) 
C
C
$C$
$C$
$C$
$C$
$C$

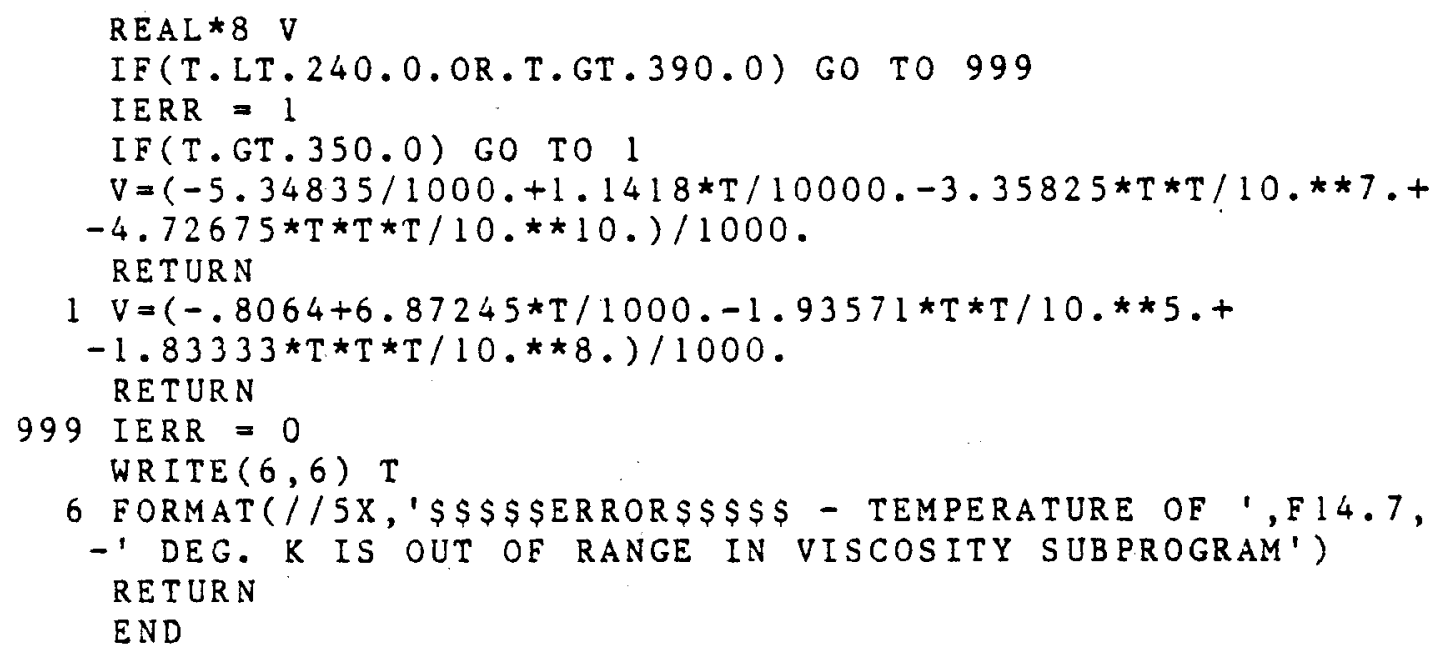

6 FORMAT $(/ / 5 X, ' \$ \$ \$ \$$ SRROR $\$ \$ \$ \$$ - TEMPERATURE OF ',F14.7, $-'$ DEG. K IS OUT OE RANGE IN VISCOSITY SUBPROGRAM' ) RETURN

END 
APPENDIX D: POWER GENERATION COST ESTIMATION

The methods of power generation cost estimation using the customary procedure and life cycle cost analysis are presented in this section.

\section{Customary Method}

All costs associated with the system under analysis are broken down into capital costs, and operation and maintenance costs. In addition, fixed charges or owning costs expressed as a percentage of investment, are determined. Fixed charges are established by the amount of capital investment in a facility and are fixed regardless of production level.

The annual fixed charges include the cost of money, funds applied to amortize investment, and charges for property, income taxes and insurance.

The cost of money depends on money market conditions in general, and on the attitude of investors toward the specific project. Funds for investor owned ventures are derived from both the risk capital (equity) and the debt capital (bonds) markets - Facilities owned by the government are generally financed by long term bonds with interest rates falling between 7 and 8 percent. In addition, government owned ventures are self-insured and are not concerned with depreciation and taxes. 
The busbar cost of electricity, using the customary method, is calculated as follows:

$$
B C=\frac{F C \times C \times 1000}{I C \times F_{a} \times 8760}+C_{0}+C_{f}
$$

where

$$
\begin{aligned}
& \text { BC - busbar cost of electricity, Mills/kWh } \\
& \text { FC - fixed charges, percent } \\
& C \text { - capital cost, dollars } \\
& \text { IC - Installed capacity, kw } \\
& F_{a} \text { - availability factor, percent } \\
& C_{0} \text { - operation and maintenance cost, Mills/kWh } \\
& C_{f}-\text { cost of fuel, Mills/kWh } \\
& \text { Life Cycle Cost Analysis }
\end{aligned}
$$

The busbar cost of electricity, using life cycle cost analysis, is calculated as follows:

$$
B C=\frac{A E \times 1000}{I C \times F_{a} \times 8760}
$$

where

$$
A E \text { - annual equivalent amount, dollars }
$$

The following section details the calculation of the annual equivalent amount. 
Calculation of the Annual Equivalent Amount

For system components not requiring replacement over the useful life of the system, the annual equivalent amount is determined as follows:

$$
A E_{1}=p \times \frac{i(1+i)^{n}}{(1+i)^{n}-1}
$$

where

$$
\begin{aligned}
& A E_{1} \text { - annual equivalent amount, dollars } \\
& P \text { - present worth of equipment, dollars } \\
& i \text { - interest rate, percent } \\
& n \text { - life of the system }
\end{aligned}
$$

For system components requiring replacement, the determination of an annual equivalent amount is more complex due to progressive increases in capital cost and escalation in the cost of borrowed capital for future replacements. Consider the cash flow for a system component requiring four replacements during the life of the system as shown in Fig. D-1. In order to project the future replacement costs ( $F C_{10}, F_{20}, F C_{30}$ and $F C_{40}$ ), the year end escalation factors for materials are used. The replacement cost at year $r$ is calculated as follows:

$$
F C_{r}=F C_{0}\left(1+i_{1}\right)\left(1+I_{2}\right) \cdots\left(1+i_{r}\right)
$$

where

$$
F C_{r} \text { - replacement cost at year } r
$$




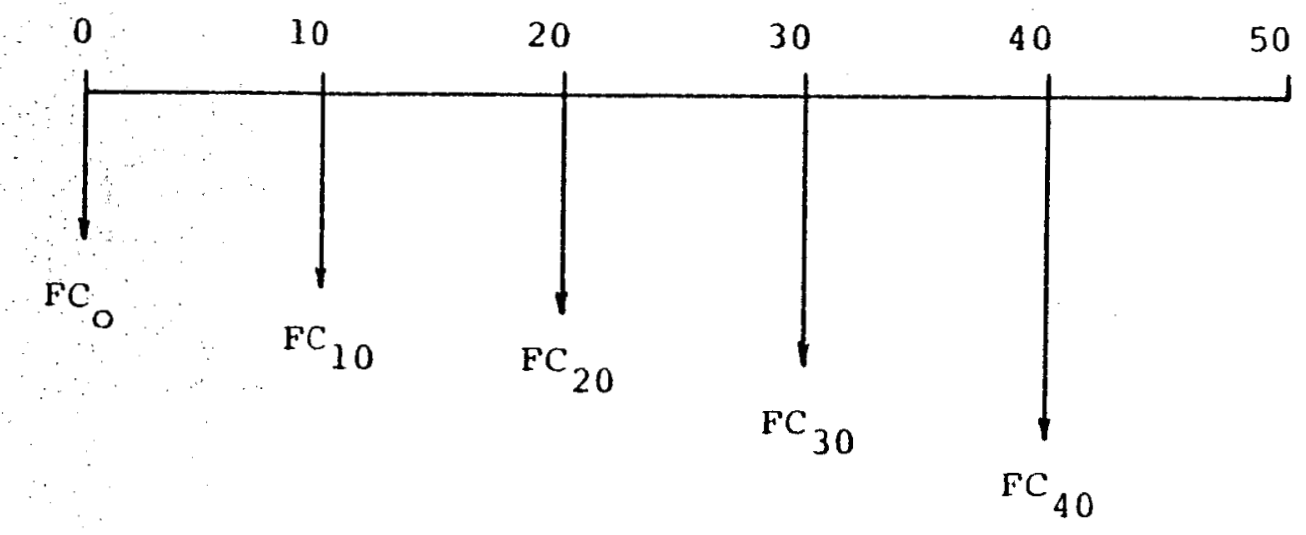

Fig. D-1 Cash flow of equipment requiring four replacements 


$$
\begin{aligned}
& F C_{0} \text { - capital cost at year } 0 \\
& i_{r} \text { - escalation factor at year } r \\
& r \text { - replacement period, years }
\end{aligned}
$$

The replacement cost in the fortieth year $\left(\mathrm{FC}_{40}\right)$ is converted to an equivalent amount at the thirtieth year as follows:

$$
\mathrm{P}_{30}=\frac{\mathrm{FC}_{40}}{\left(1+i_{30}\right)^{10}}
$$

where

$$
\begin{aligned}
& \mathrm{P}_{30} \text { - equivalent amount of the fourth replacement cost } \\
& \text { at the thirtieth year } \\
& \text { i }_{30} \text { - interest rate at the thirtieth year }
\end{aligned}
$$

Thus, the cash flow has been reduced to an equivalent cash flow as shown in Fig. D-2. By successive calculations using the appropriate year end interest rates, the replacement costs can be reduced to a single present worth amount $\left(P^{\prime}\right)$ at year 0 . The annual equivalent amount, over the life of the system, is then determined using the present interest rate.

$$
A E_{2}=P ! x \frac{1_{1}\left(1+i_{1}\right)^{n}}{\left(1+i_{1}\right)^{n}-1}
$$

where

$$
\mathrm{P}^{\prime} \text { - present worth of all equipment replacements }
$$




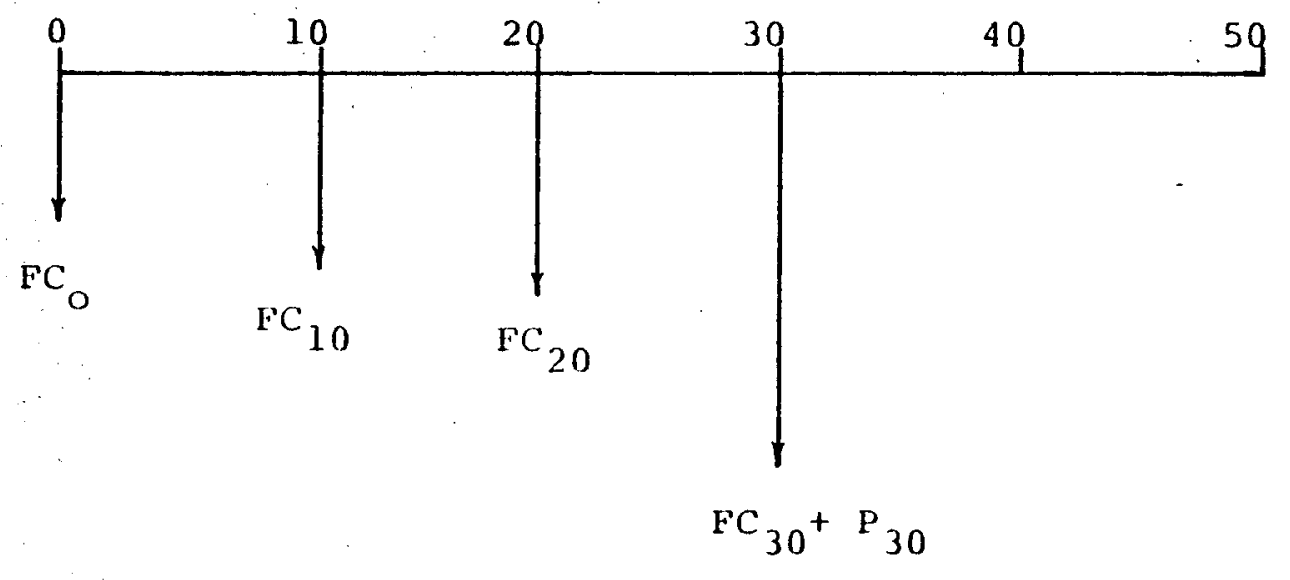

Fig. D-2 Reduced cash flow of equipment requiring four replacements 
104

Similarly, the annual equivalent amount $\left(\mathrm{AE}_{3}\right)$ for operation and maintenance costs is calculated using the appropriate year end escalation rate for labor and materials.

The total annual equivalent amount is determined as the sum of all the individual annual equivalent amounts.

$A E=\sum A E_{i}$

$(c-7)$

Mepient + Pouf. Nape tenoned $12 / 17 / 80$ 